\title{
RECENT JUdicial DeVelopments OF INTEREST TO OIL AND GAS LAWYERS
}

\section{DAVID J. STANFORd AND SEAN S. SMYTH"}

This article is intended to provide a brief review of recent Canadian judicial decisions of interest to oil and gas lawyers. The atwhors have surveyed Canadian case law in the areas of goverumem regulation. contract, employmen, righis offirst refusal, royalies, injunctions, freehold leases, and other areas.
Cet article a pour but de donner un apercu des récentes décisions judiciaires canadiennes intéressant les awocats travaillamt doms to domaine pétrolier et gazier. Les anturs oni fail le tour de la jurisprudence canadienne dans les domaines de la réglementation gouvernementale, des contrats, de l'emploi, des droits de premier refus, des redevances, des injonctions, des baux froncs ef autres.

\section{TABLE OF CONTENTS}

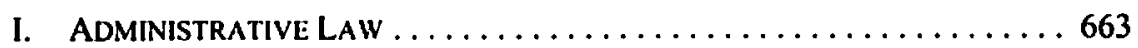
A. PROVIDENT ENERGY LTD. $V$.
ALBERTA (SURFACE RIGHTS BOARD) .................66 663
B. ATCO GAS AND PIPELINES LTD. V.

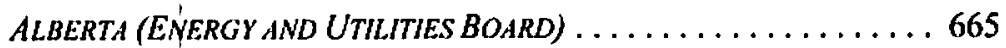
C. ALLIANCE PIPEIINE LTD. V. ALBERTA
(MINISTER OF MUNICIPAL AFFAIRS) $\ldots \ldots \ldots \ldots \ldots \ldots \ldots 66$

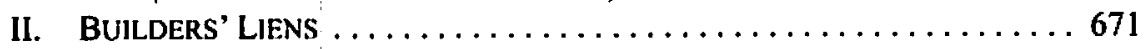

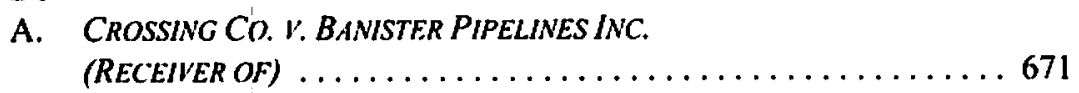

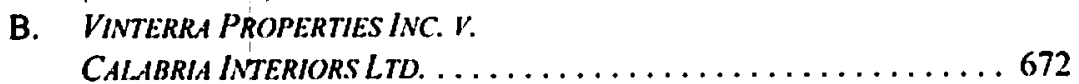

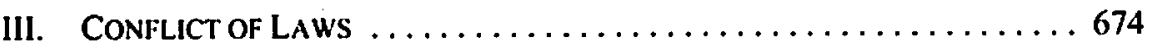

A. ALLIANCE PIPELINE LTD. PARTNERSHIP V.

FRANKLIN (C.E.) LTD. ........................ 674

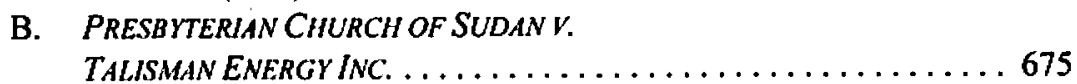

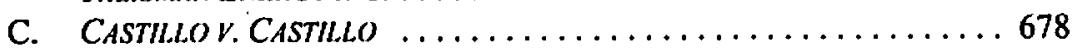

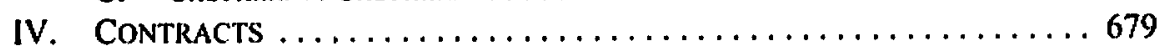

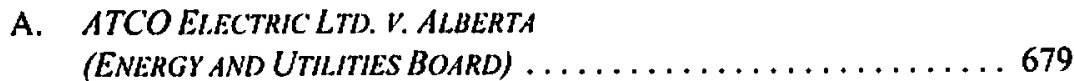

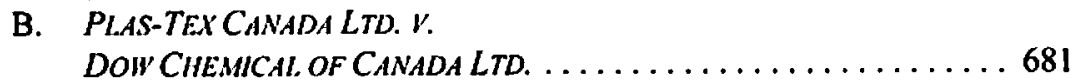

C. EAGLE RESOURCES LTD. V. MACDONALD ............ 683

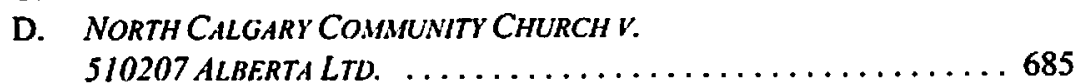

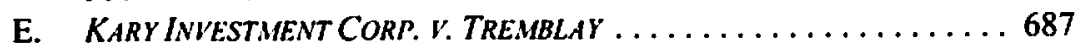

McCarthy Tétrault L..P, Calgary, Alberta. The authors gratefully acknowledge the following partners and associates of MeCarthy Tétrault LLP whose assistance was invaluable in the preparation of this article: Keith Byblow, Robern Depoe, Derek Flaman, Tina Giesbrecht, David Izet1, Brandon Kain, Derek Kearl, Robert Nearing, and Jeremy Trickett. 
V. Creditors' Rights . . . . . . . . . . . . . . . . . . . . . . . 690

A. CRYSTALLINE INVESTMENTS LTD. V. DOMGROUP LTD. . . . . . . . 690

B. RESTELCOINC. .......................691

C. DIRECT ENERGY MARKETING LTD. V.

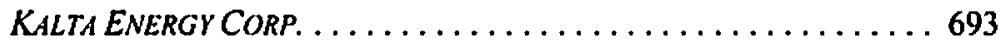

VI. EMPLOYMENT . . . . . . . . . . . . . . . . . . . . . . . . 694

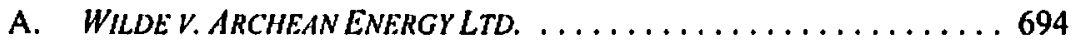

B. ALBERTA (HUMAN RIGHTS \& CITIZENSHIP COMMISSION) $V$.

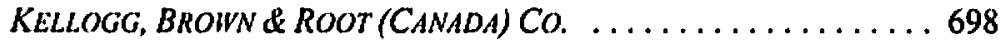

C. TELUS COMMUNICATIONS INC. $V$.

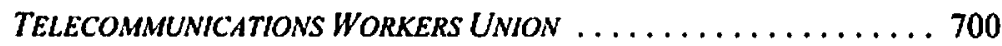

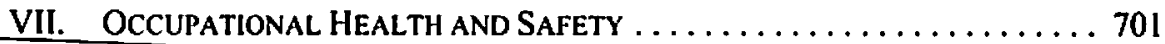

A. R. V. ALTAPRO CLEANING \& DISASTER RESTORATION LTD. . . . . . . 701

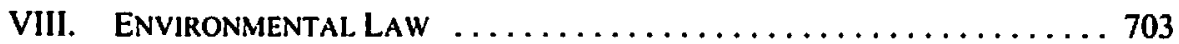

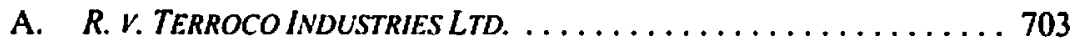

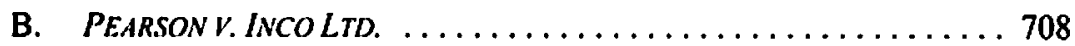

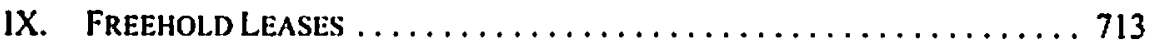

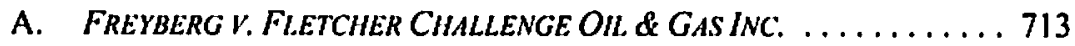

B. KENSINGTON ENERGY LTD. V. B\&G ENERGY LTD. . . . . . . . . . 717

X. Guarantees ............................. 720

A. KKBL NO. 297 VENTURES LTD. $V$.

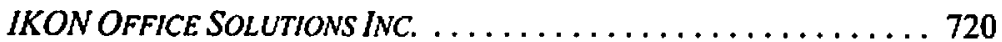

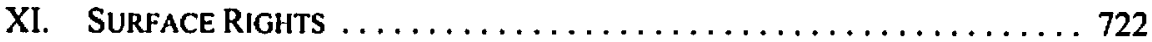

A. MARITIMES AND NORTHEAST PIPELINE LTD.

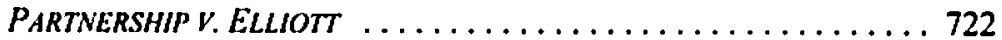

B. IMPERIAL OLI RESOURCES LTD. V.

826167 ALBERTA INC. . . . . . . . . . . . . . 724

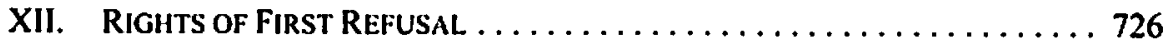

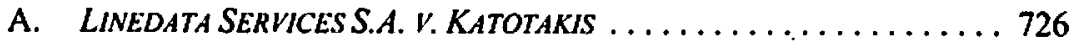

B. APEX CORP. V. CECO DEVELOPMENTS LTD. . . . . . . . . . 728

C. PETROKAZAKHSTANINC. $V$.

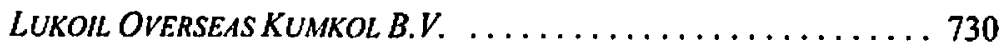

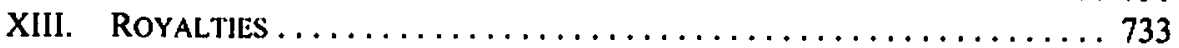

A. JAMES H. MEEK TRUST V. SAN JUAN RESOURCES INC. . . . . . . 733

B. MISSILINDA OF CANADA LTD. V.

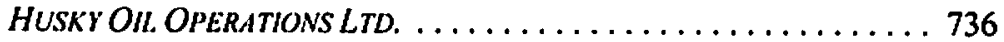

C. R.W. MITTEN ENTERPRISES LTD. V.

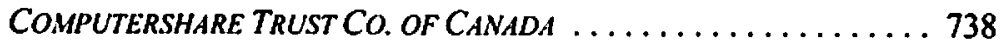

XIV. SET-OfF ............................ 739

A. RE ANDROSCOGGIN ENERGY LLC ................ 739

B. 918339 ALBERTA LTD. $V$.

569244 BRITISH COLUMBIA LTD. . . . . . . . . . . . . . . 740

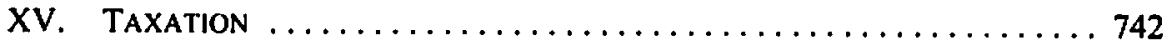

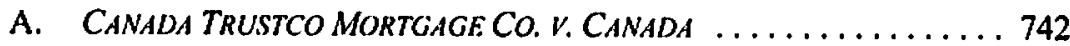

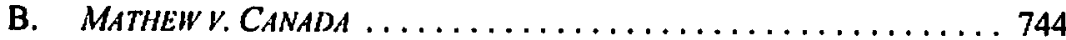

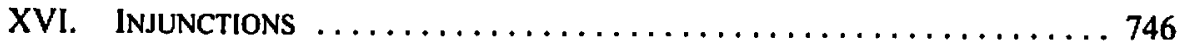

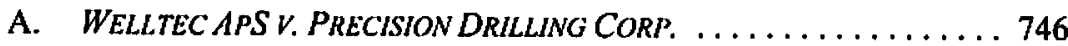


B. L.P.I. V. 000 ALBERTA LTD. ................. 751

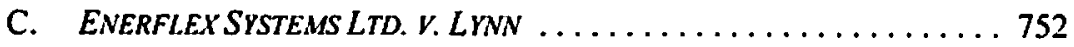

D. MEDICAL LABORATORY CONSULTANTS INC. $v$.

CALGARY HEALTH REGION ...................... 753

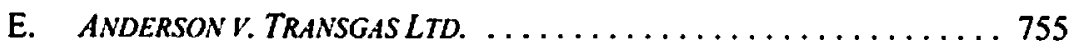

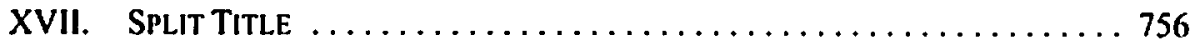

A. XEREX EXPLORATION LTD. V. PETRO-CANADA ........... 756

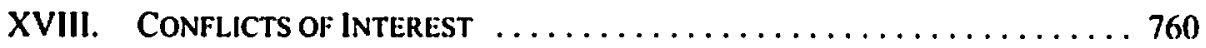

A. 3464920 CANADA INC. v. StROTHER ............... 760

\section{Administrative Law}

A. Provident ENERGY LTD. V. ALberta (SURFACE RIGHTS BOARD)'

\section{l. BACKGROUND}

Provident Energy Ltd. (Provident), the successor by amalgamation to the lessee under a dormant surface lease, disputed a decision of the Surface Rights Board (SRB), which recognized the current landowners' claim for payment under the surface lease and ordered compensation.

\section{FACTS}

Tai Resources Ltd. (Tai), a predecessor by amalgamation to Provident, and the predecessor by sale to the current landowner, had entered into a surface lease in 1984. Tai drilled a dry hole on the subject lands and the Energy Resources Conservation Board (ERCB; now the Alberta Energy and Utilities Board or AEUB) authorized Tai to abandon the well. Tai took no further interest in the well and did not register a caveat on title. No reclamation certificate was ever obtained by Tai or any of its successors, and no further payments were made under the surface lease. Approximately 19 years later, the current landowners discovered the well site and the surface lease, and filed an application with the SRB seeking relief under s. 36 of the Surface Rights $A c t,{ }^{2}$ claiming unpaid annual rents.

After a hearing, the SRB found that the surface lease remained in effect, relying on s. 144 of the Environmental Protection and Enhancement $\mathrm{ACt}^{3}{ }^{3}$ which requires that a reclamation certificate be acquired in order for the surrender or termination of a surface lease to be effective. The SRB also directed the Provincial Treasurer to pay the landowners compensation based on reduced crop yields because of compaction in the well site area that would not have existed had that area been properly reclaimed. 
Provident sought judicial review of the SRB's decision. At issue before Erb J. was: (1) whether the SRB made a reviewable error by accepting the landowners' claim for unpaid rates; and (2) whether the application was barred by the Limitations $A c t .^{4}$

\section{DECISION}

Justice Erb began by considering the appropriate standard of review to apply, noting that the Supreme Court of Canada has held that the "pragmatic and functional approach" should be taken in assessing what standard of review to apply in an administrative decision." Adopting this approach, Erb J. noted that the Supreme Court established, in Pushpanathan, the four-part test that must be applied: (1) the presence or absence of a privative clause or right of appeal in the governing statute; (2) the tribunal's expertise versus the expertise of the reviewing court on the issue; (3) the purpose of the governing statute and section at issue; and (4) the nature of the issue (law, fact, or mixed law and fact) in question. ${ }^{6}$ Assuming on the facts that no single factor should be viewed as determinative, the court is to consider all of the factors to determine the level of deference that should be given to the board: if little deference should be accorded, a standard of "correctness" applies; if a high degree of deference is to be applied, a standard of "patent unreasonableness" should be used; and linally, if the appropriate level of deference lies in between, the appropriate standard of review is one of "reasonableness simpliciler."

Justice Erb noted that the Surface Rights Acl contains no privative clause or statutory right of appeal. Then, quoting from prior decisions of the Court, she found that the SRB was established to do specialized work and that its members are experts with extensive knowledge and experience in the areas of public policy, acceptable oil and gas industry practices, and concerns of landowners. Justice Erb further found that "the purpose of Section $144(1)$ of the EPEA is to offer an inexpensive and practical means of preventing oil companies from circumventing the requirement to obtain a Reclamation Certificate," and that the purpose of s. 36 of the Surface Rights $A c t$ is to provide a mechanism by which surface owners are guaranteed compensation to which they are entitled. Finally, Erb J. found that the issues before the SRB were whether the surface lease remained valid and, if so, whether outstanding rent remained payable, and whether there were sufficient circumstances to justify the SRB exercising its discretion under the Surface Rights Act to direct the Provincial Treasurer to pay compensation to the lessors.

Justice Erb concluded that all of these matters were within the purview of the SRB, and that it should be accorded a high degree of deference. Accordingly, the proper standard of review was one of "patent unreasonableness." Justice Erb observed that the threshold for overcoming this standard is very strict and, quoting Cory J., stated that it is only met where

R.S.A. 2000, c. L-12. Provident argued that the Limisations Act applied to bar the landowners' claim for all but the last two years of the lease. Justiee Erb found that the Limitations Act did not apply because the SRB is a statutory body that is not subject to the provisions of the $A c t$.

3 See U.E.S. Local 298 v. Bibeault, [1988] 2 S.C.R. 1048 and Pushpanathan v. Canada (Minister of Citizenship and Immigration), [1998] I S.C.R. 982 [Pushpanathan].

Pushpanathan, ibid. at paras. 29-38.

Sipra note 1 at para. 26. 
the tribunal's decision is "clearly irrational, that is to say evidently not in accordance with reason."8

Based on the foregoing analysis, the Court held that the SRB's decision was not patently unreasonable and dismissed the application in its entirety:

The Board applied a straight line approach. It added up the facts; it found that lease payments had not been made. It investigated further, it found that section 144 of the EPEA had not been complied with and that such non compliance meant the [leasc] was stil] viabls. This conclusion did not require a high level of interpretation. Section 144 stules this quile clearly."

Lastly, Erb J. held that as the SRB is a statutory body, it is not subject to the Limitations $A C t$, and the lessors are therefore entitled to compensation based on the entire period of their claim.

\section{COMMENTARY}

Although Erb J.'s analysis of the Pushpanathan test is convincing and provides helpful guidance on how that test should be applied, this decision arguably has more day-to-day relevance to the oil and gas industry for its consideration of s. 144 of the EPEA and its effect on unreclaimed surface leases. There should now be little doubt in Alberta that, notwithstanding the absence of a privative clause in the Surface Rights Act, a decision of the SRB will be difficult to set aside on judicial review, unless the critical issue before it was entirely or mostly legal in nature, and its analysis of that issue was clearly wrong at law. There should be even less doubt as to whether or not a dated surface lease for which no reclamation certificate has been obtained remains valid and, therefore, the source of potential historical claims against its current and former lessees.

\section{B. ATCO Gas and Pipelines Ltd. V. ALbERTa (ENERGY AND UTILITIES BOARD) ${ }^{10}$}

\section{BACKGROUND}

The Alberta Court of Appeal, in a thorough analysis of the Pushpanathan factors, found that the test of prudence applied by the Alberta Energy and Utilities Board (AEUB or the Board) in assessing ATCO's managerial decisions was appropriate, and that the AEUB's application of that test was not reviewable.

\section{FACTS}

ATCO Gas and Pipelines Ltd. (ATCO) sought to appeal a decision of the AEUB that found that ATCO acted imprudently in managing its gas supplies for the winter of 2000-2001 when it changed from a flexible withdrawal strategy, dependent on seasonal fluctuations in 
demand, to a flat withdrawal strategy whereby it withdrew gas at a set monthly flat rate from its Carbon, Alberta gas storage facility. According to the AEUB, ATCO ought to have acted differently to mitigate high winter gas prices. In finding that ATCO had acted imprudently, the AEUB ordered ATCO to compensate its customers for missed cost savings that would have been realized had ATCO not changed its withdrawal strategy. ATCO appealed the AEUB's decision to the Court of Appeal " on the sole issue of whether the AEUB erred in law in determining the appropriate standard to apply with respect to the prudence and reasonableness of ATCO's decision.

\section{DECISION}

The following summarizes the Court of Appeal's analysis of the Pushpanathan test, used to determine the appropriate standard of review to be accorded to the AEUB's decision.

\section{a. Privative Clause}

The Court noted that both the Alberta Energy and Utilities Board Act' ${ }^{2}$ and the Public Uititities Board $A c^{13}$ grant jurisdiction to the AEUB to hear and determine all questions of law and fact. Both statutes allow for appeals from AEUB decisions on questions of law or jurisdiction, implying a legislative intent to afford the AEUB less deference on its findings of law or fact. However, the Court confirmed that matters falling within the AEUB's expertise will still warrant deference, notwithstanding the presence of a statutory right of appeal.

\section{b. Relative Expertise}

The Court found that the question of whether the AEUB erred in determining that the appropriate standard of review of the prudence and reasonableness of ATCO's decision to change withdrawal strategies could either constitute a question of legislative interpretation or a mixed question of statutory interpretation and industry-specific practice. The Court found that the question is one of law, which would normally suggest that the Court would have greater expertise than the AEUB, and would militate against affording it a significant level of deference. However, the Court noted that, in this case, the legal question (whether the Board adopted the proper test of prudence) was enunciated by the AEUB in the context of setting proper rates for a public utility, which is squarely within its expertise. Accordingly, the Court found that its expertise did not exceed that of the AEUB, suggesting that the Board should be afforded curial deference.

\section{c. Purpose of the Legislation}

The Court stated that the AEUB's mandate is to protect the public interest by way of regulating public utilities. It concluded that where the statutory scheme governing a tribunal

"Leave granted in ATCO Gas and Pipelines LAd. v. Allerla (Energy and Uilities Bexard), 2003 ABCA 188, [2003] A.J. No. 735 (QL). The chambers judge expressly denied leave on the AFUI3's calculation of the amount of the reliund.

I2 R.S.A. 2000 , c. A-17. s. 26.

1) R.S.A. 2000, c. P-45. s. 70. 
allows that tribunal to balance competing interests and address broad policy concerns, a court sitting in judicial review of the tribunal's decisions in that regard should approach them with a large measure of deference. Further, the legislation giving the AEUB the authority to fix "just and reasonable rates" suggested to the Court that the criteria within which the AEUB exercises its powers is deliberately flexible and discretionary and should therefore be subject to limited review. The discretion to determine what is just and reasonable includes the discretion to define justness and reasonableness. ${ }^{14}$

\section{d. Nature of the Issue}

Finally, the Court concluded that despite leave only being available on questions of law or jurisdiction (suggesting a lesser level of deference), because the question related to the management of a utility and its marketing strategies, some deference should be accorded to the AEUB's decision, as this was something with which it had greater expertise than the Court.

Based on its analysis of the four Pushpanathan factors. the Court noted that only the statutory right of appeal criterion suggested a less deferential standard; all of the other factors suggested a higher degree of deference. Accordingly, the Court ruled that the appropriate standard of review was reasonableness simpliciter, which requires it to ask "whether there is a rational basis for the decision ... in light of the statutory framework and the circumstances of the case."'s

Accordingly, the Court concluded that "[t]he only matters at issue on this appeal are whether the Board properly acknowledged a presumption of prudence, and properly articulated the test of prudence, in assessing ATCO's management decisions." ${ }^{\text {"16 }}$ The Court held that the appropriate standard of prudence is what a reasonable public utility (rather than a reasonable businessman) would have done in the circumstances, and concluded that the AEUB properly acknowledged the test of managerial prudence. lis articulation of the test was "consistent with its previous decisions and with the line of authority addressing the concept of prudence in the context of public utilities." ${ }^{17}$ Given that the AEUB had satisfied itself that ATCO's change in withdrawal strategy was unreasonable, the Court of Appeal held that the AEUB had proceeded properly when it ordered ATCO to compensate its customers for cost savings lost as a result of the imprudent conduct.

\section{COMMENTARY}

While the Court of Appeal's decision as a whole is sound, its finding that the AEUB had a greater level of expertise than itself to consider a legal question (i.e., whether or not the proper test of prudence had been adopted) could be viewed as somewhat unusual. The Court came to this conclusion because the AEUB had "enunciated its test of prudence in the

Memorial Gardens Association (Canada) Lud. v. Colwood Cemetary Co., [1958] S.C.R. 353 at 357: TrunsAlia Utilities Corp. V. Alberta ('P'ublic Unilities Board) (1986), 68 A.R. 171 (C.A.) at para. 24.

is Re Cartaway Resources Corp., 2004 SCC 26, [2004] I S.C.R. 672 at para. 49.

16 Supra note 10 at para. 74.

17 ibid. 
context of rate-setting."18 However, it seems difficult to conceive of how an administrative tribunal such as the AEUB could enunciate any legal test in a context other than one that goes to the essence of its very purpose and the issues it is established to regulate. Taken to its logical extreme, this finding suggests that, as long as an administrative tribunal that is required to apply a particular test established by the courts does so in the context of its primary raison d'être (or one of them), a court sitting in judicial review of the manner in which it applied the particular test must defer to the tribunal's expertise as being superior to its own. This was almost assuredly not the Court's intention in this case, but its failure to clarify its finding beyond the little guidance it gave seems to at least beg this question.

\section{ALLIANCE PIPELINE LTD. V. ALBERTA \\ (MINISTER OF MUNICIPAL AFFAIRS) ${ }^{19}$}

\section{BACKGROUND}

This is the Alberta Court of Appeal's decision overturning the decision of the Alberta Court of Queen's Bench that was included in the 2006 edition of this article. ${ }^{20}$ The Court considered the interpretation of a provision of the Municipal Government Act that exempts gas pipelines from taxation prior to completion unless they are "capable of being used for the transmission of gas."21

\section{FACTS}

In the spring of 2001, the Ministry of Municipal Affairs presented Alliance Pipeline Ltd. (Alliance) with a series of municipal tax assessments (collectively, the assessment), dealing with the value of the Alberta portion of a pipeline owned by Alliance. The assessment date was 31 October 2000 and, although fabrication and field installation of the pipeline had been completed by that date, pressure testing had not been completed and the pipeline had not been commissioned. Alliance objected to the assessment and filed a complaint with the Municipal Government Board (MGB), arguing that, under s. 291(2)(a) of the $M G A$, the pipeline was entitled to a statutory exemption from taxation for the 2001 tax year because it was neither complete nor capable of being used for the transmission of gas on 31 October 2000. Alliance argued that on 31 October 2000 , the pipeline was still under construction and had neither been fully commissioned nor tested for safety. As a consequence, the pipeline was not assessable because it was not yet "capable of being used for the transmission of gas."

Hearings took place before the MGB. In its written reasons following the hearings, the MGB stated that it had adopted a purposive approach to the interpretation of s. 291(2)(a) and found that its purpose was two-fold: 1) to prevent the avoidance of assessment; and 2) to ensure that linear property owners are not taxed before they have the realizable potential to

Ibid. at para. 43.

2006 ABCA 9, 376 A.R. 44.

Mark Hlouston et al., "Recent Judicial Developments of Interest to Oil and Gas Lawyers" (2006) 44 Alta. L. Rev. 233 at 239.

"I R.S.A. 2000, c. M-26, s. 29l(2)(a) [MGA]. In its entirety, s. 291(2)(a) reads: "No assessment is to be prepared for linear property that is under construction but nol completed on or before October 31 , unless it is capable of being used for the irunsmission of oil, gas or electricity" [emphasis added]. 
use the property for its intended purpose. Then, after a discussion of what was meant by the words "capable of being used for the transmission of gas," the MGB concluded that because test gas had passed through the pipeline, in "significant amounts," the pipeline was "capable of being used for the transmission of gas."

Upon application by Alliance for judicial review, ${ }^{22}$ the chambers judge considered the analysis from Pushpanathan ${ }^{23}$ and concluded that the MGB's decision deserved a high degree of deference and that the correct standard of review to apply was one of patent unreasonableness. Applying that standard, he dismissed Alliance's application. Alliance appealed.

\section{DECISION}

At the outset of her analysis, Conrad J.A., writing for the Court, noted that the Supreme Court of Canada has clarified the role of an appellate court in an appeal from a lower court's decision on an application for judicial review. ${ }^{24}$ The role of the appellate court is to determine whether the reviewing judge chose and applied the correct standard of review, and in the event it did not, to assess the administrative body's decision in light of the correct standard. According to the Supreme Court, the question of the right standard to select and apply is one of law and, therefore, must be answered correctly. If the appellate court confirms the lower court's selection of the standard of review, it is still obliged to assess the lower court's application of that standard, and in doing so it must apply a standard of correctness.

Noting that none of the factors established by the Supreme Court of Canada in Pushpanathan are determinative, the Court stated that each factor must be considered and weighed in order to determine the proper level of deference for the issue in question.

Respecting the presence or absence of a privative clause, the Court noted that while the $M G A$ does not contain a proper privative clause, it does provide that there is no appeal from a decision of the MGB. The Court held that such a provision is a weak privative clause pointing to a moderate degree of deference. Concerning the MGB's expertise, the Court cited its own decision in Alberla (Workers' Compensation Board) v. Alberla (Workers' Compensation Board Appeals Comission), ${ }^{25}$ where it stated:

The reviewing courn must consider both the general expertise of the tribunal, and its expertise on the particular question on appenl. The court must then compare the tribunal's expertise to its own... Greater deference will be called for only when the decision-making body is, in some way, more expert than the cour, and the question under consideration falls within the ambit of this expertise. ${ }^{26}$

Dealing first with the characterization of the MGB's general expertise, the Court held that there is nothing in the $M G A$ to indicate that members of the MGB are required to have any

See Alliance Pipeline L.td. 4. Alheria (Minister of Municipal Affairs), 2004 ABQB IIS. 353 A.R. 182. Supra note 5.

See Dr. Q. v. College of Physicians \& Surgeons of British Cohmbia, 2003 SCC 19, [2003] I S.C.R. 226

[Dr. Q.].

2005 ABCA 276, 317 A.R. 318.

lbid. at para. 36. 
particular expertise. Acknowledging existing jurisprudence that a tribunal can accrue expertise by repeatedly determining issues in a particular subject area, ${ }^{27}$ the Court noted that the MGB has developed expertise in property assessment. Nevertheless, the Court concluded, noting the MGB's own approach to its analysis, that the specific question on appeal required expertise in statutory interpretation and not expertise in municipal assessment, which therefore suggested a lesser degree of deference:

\begin{abstract}
Interpreting the phrase "capable of the transmission of gus" involves, as the Board acknowledged (at 52 of its Order), the application of the principles of statutory interpretation, such as "the purposive approach" and the "plain and ordinary muaning". These are techniques of stututory construction that the courts apply with regularity and, certainly, it cannot be said the Board is more expert than the court in dealing with such matters.... It follows that the issue of expertise does not favour deferenee with respect to the particular question on appeal. ${ }^{28}$
\end{abstract}

Respecting the purpose of the legislation in question, Conrad J.A. quoted McLachlin C.J.C. in Dr. $Q$. to establish the principles guiding this analysis:

\begin{abstract}
As a general principle, increased deference is called for where legislation is intended to resolve and balance competing policy objectives or the interests of various constituencies... In contrast, a piece of legislation or a statutory provision that essentially seeks to resolve disputes or determine rights between two parties will demand less deference. ${ }^{29}$
\end{abstract}

The Court held that the $M G A$ determines rights between the taxpayers and Alberta's municipalities, rather than resolving a balancing of policy objectives between constituencies, favouring the application of the correctness standard.

Lastly, considering the question of the nature of the issue before the MGB, the Court held that the issue before the Board was the proper interpretation of the $M G A$, which is a matter of law that does not fall within the Board's sphere of expertise. Accordingly, a consideration of this factor favoured applying the correctness standard.

Noting that the only factor favouring deference to the MGB's decision was the absence of a right to appeal, the Court of Appeal concluded that the proper standard of review was correctness, and that the trial judge had erred in applying a standard of patent unreasonableness.

Applying the correctness standard to the MGB's analysis of s. 291(2)(a) of the MGA, the Court found that the MGB's interpretation of that section was too broad to comply with the purpose of the $M G A$, and that the correct interpretation of the phrase "capable of being used for the transmission of gas" is that the pipeline is "capable of being used for its intended purpose - the safe, commercial transportation of gas." 
correct in finding that one of the reasons why the $M G A$ contained these words was to "discourage deliberate or inadvertent delay in construction to escape tax liability." 11 However, the Court held that the fundamental problem with the MGB's overall interpretation was that it "could impose liability, with regularity, on those who have no intention of avoiding municipal taxation," 32 which in the Court's view was the case here.

Accordingly, the Court upheld Alliance's appeal and quashed the MGB's decision. Also, as the record showed that the pipeline was not "capable of being used for the transmission of gas" on 31 October 2000 , the Court held that the assessor was not obliged to make an assessment, and granted Alliance's application for a declaration to this effect.

\section{COMMENTARY}

Justice Conrad's judgment contains at least two additional noteworthy points. First, she added that even if she was wrong on her assessment of the standard of review to apply, such that the standard of patent unreasonableness applied by the lower court was correct, the MGB's failure to enter into considerations of the pipeline's safety and commercial transportation capacity amounted to a patently unreasonable interpretation of s. 29/(2)(a) of the $M G A$. Second, Conrad J.A. noted that the normal relief granted in this case would be to refer the matter back to the MGB for reconsideration with the corrected error, but that "nothing would be gained by doing that here"33 because the facts were not in dispute and, given the Court's order, there was no basis on which an assessment could be prepared.

Some may view the MGB's decision as an attempt to find a way to justify assessing the Alliance pipeline for the 2001 taxation year. Others could reasonably conclude that Alliance was attempting, artificially, to avoid being assessed until 2002. Either way, the Alberta Court of Appeal has sent a clear message to administrative tribunals that where the issue before them is one of statutory interpretation or some other question that is clearly legal in nature, the tribunal had better be certain that its analysis of that issue is completely correct at law, especially if the entire foundation of its decision rests upon it.

\section{BUILDERS' LIENS}

\section{A. Crossing Co. v. Banister Pipelines INC. (Receiver of) ${ }^{34}$ \\ 1. BACKGROUND}

The hiring and payment of contractors and subcontractors happens on a daily basis in the petroleum industry. This decision underscores the fact that the value to a contractor or subcontractor of a properly registered builders' lien can extend beyond the protection and leverage that the contractor derives from encumbering the land with its lien. 


\section{FACTS}

Enbridge engaged Banister Pipelines Inc. (Banister) to construct a pipeline. Banister subcontracted work to The Crossing Company Inc. (Crossing), which registered a builders' lien, supplemented by a lien bond for $\$ 3$ million. Litigation ensued between Crossing, Banister, and Enbridge, with Banister and Enbridge settling in consideration for \$2 million being paid by Enbridge to Banister. Crossing was successful against Banister at trial and received a judgment for approximately $\$ 2.7$ million, plus interest and costs. ${ }^{35}$ Banister then went into receivership with PricewaterhouseCoopers Inc. $(\mathrm{PwC})$ as receiver. At issue before the Alberta Court of Queen's Bench was whether PwC held the \$2 million settlement paid to Banister by Enbridge in trust for the benefit of Crossing and, if so, whether the funds were available to satisfy Crossing's claim for interest as granted in the judgment.

\section{DECISION}

Justice Perras held that s. 6 of the Builders ' Lien Act ${ }^{36}$ operates to create a lien, while s. 22 of the $A c /$ creates a trust where the owner pays money over to a principle contractor. Since Crossing had a valid lien and a judgment for an ascertained amount, the judgment met the test under s. 2(1) of the Judgment Interest Ac ${ }^{37}$ and, as a result, the interest formed part of the price of the work or materials for the purpose of enforcing the lien and was recoverable. The Court further held that s. 31 of the Builders ' Lien Act provides that the lien is not merged by taking of security. Accordingly, the Court held that even though Crossing received \$3 million from the lien bond, it was still able to claim on the $\$ 2$ million held by PwC pursuant to the original lien to fulfill its judgment.

\section{COMMENTARY}

From a public policy perspective, it is important that contractors know that they can conduct their work knowing that the statutory protections given them have value and are enforceable, subject only to clearly understood rules concerning priority and assuming they meet the requirements to avail themselves of those protections. Otherwise, no reasonable contractor would provide its services on credit to any significant extent. This is the policy underlying statutes such as the Builders ' Lien Act, and this decision is consistent with that policy.

B. VINTERRa PRoperties INC. V. CALABRIA INTERIORS LTD. ${ }^{3 *}$

1. BACKGROUND

Vinterra Properties Inc. (Vinterra) applied for an order vacating and discharging a lien filed against its property by Calabria Interiors Ltd. (Calabria) on the grounds that the lien was

is Uanister appealed the Irial judge's decision to the Alberta Court of $A$ ppeal, which dismissed the appeal. See 2005 ABCA 21, 40 C.L.R. (3d) 42.

R.S.A. 2000 , c. B-7.

R.S.A. 2000, c. J-1.

2005 ABQB 130, 377 A.R. 60. 
not registered within $\mathbf{4 5}$ days from the date that services or materials were furnished as required by s. 4 of the Builders ' Lien Act. ${ }^{39}$

\section{FACTS}

Vinterra hired Calabria to supply and install condominium fixtures. At issue was the timing of the installation of a bulkhead covering an exhaust pipe. Calabria filed its lien on 5 September 2003. Both parties submitted into evidence a number of documents in an attempt to demonstrate the date on which the installation of the bulkhead was completed.

\section{DECISION}

As an initial observation, a matter of civil procedure evolved into one of the main issues in this case. The issue was which party bore the onus of proving that the lien had been properly or improperly registered. Vinterra's counsel had opted to proceed by way of Originating Notice of Motion; accordingly, standard rules of civil procedure require that Vinterra, as the petitioning party, bear the burden of proving that the lien had not been properly registered. Vinterra, however, submitted that the burden in a builders' lien case is on the party that registered the lien to prove that it was, in fact, properly registered.

In his reasons for decision, Marceau J. noted that the Builders' Lien Act is silent on this point and, quoting the Alberta Court of Appeal in Slater v. Burgoin," held that "[a]bsent guidance in a specific rule or statute, the general rule of procedure is that the person who asscrts must prove," on the point. Interestingly, however, the Court pointed out that Vinterra could have proceeded by way of Notice to Prove Lien under s. $48(3)$ of the Builders ' Lien Act, which would have operated to place the onus on Calabria. Vinterra chose otherwise, however, and "must accept the consequences of its procedural choices." $\$ 2$

Even though it bore the onus of proving the invalidity of Calabria's lien, Marceau J. held that Vinterra successfully discharged this onus by the evidence it brought before the Court. The Court found that much of the evidence adduced by Calabria was inconsistent and presented concerns as to its credibility as a whole, whereas Vinterra's evidence was consistent throughout. On the balance of probabilities, the evidence supported Vinterra's position as to the date on which the bulkhead was completed, and therefore the Court granted Vinterra's application.

\section{COMMENTARY}

Although Vinterra was ultimately successful, its choice to proceed by way of Originating Notice of Motion instead of by way of Notice to Prove Lien could have been disastrous. Counsel who overlook procedural options available to their clients, such as statutory 
impositions of onus on the other party to a dispute, do so at the peril of their clients and may unwittingly cause themselves and their procedural choices to become one of the main issues within the dispute.

\section{CONFLict Of LawS}

\section{A. Alliance Pipeline Ltd. Partnership V. Franklin (C.E.) Lto. ${ }^{43}$ \\ l. BACKGROUND}

Numerous commercial agreements in the oil and gas industry contain "forum selection" clauses stipulating that a dispute arising out of the agreement must be commenced within a specific jurisdiction. This case illustrates the need for precision in the drafting of such clauses.

\section{FACTS}

The plaintiffs were American and Canadian limited partnerships that purchased compressor valves for use in their pipeline stations from the defendant German manufacturers. The purchase was made by an agent of the plaintiffs from a Canadian company (the Third Party), which acted as the defendants' Canadian distributor and sales agent. The purchase orders, which were issued and accepted in Alberta, contained a choice of law clause identifying Alberta as the governing law. However, the purchase orders did not contain a forum selection clause, and made reference to a set of conditions that the defendants alleged were certain German conditions providing that proceedings arising out of the purchase were to be brought in Germany. The agency agreement between the Third Party and the defendants also contained a forum-selection clause in favour of Germany.

The plaintiffs claimed that the compressor valves were defective, and brought an action against the defendants and the Third Party seeking damages for negligence, breach of contract, and breach of implied warranties under the Sale of Goods Act. ${ }^{\text {th }}$ The Third Party filed a third-party claim against the defendants. The plaintiffs and Third Party each obtained service ex juris orders against the defendants, and the defendants subsequently brought a failed application to set aside the order in favour of the plaintiffs primarily on evidentiary and fortum non conveniens grounds, and the order in favour of the Third Party primarily owing to the forum-selection clauses. The defendants appealed the dismissal of their application with respect to the American plaintiff and the Third Party.

\section{DECISION}

The Court of Appeal dismissed the appeal from the decision to affirm the American plaintiffs service ex juris order for evidentiary reasons. 
With respect to the appeal from the Third Party's service ex juris order, the Court noted that the agency agreement between the defendants and the Third Party governed matters of agency and commission rather than the dispute that gave rise to the third-party claim and, therefore, held that its forum selection clause was irrelevant to the Third Party's ability to commence a third-party action outside of Germany.

The Court then considered the conditions allegedly appended to the purchase order and found that there was insufficient evidence to conclude that the conditions relied upon by the defendants were actually attached to the orders, or were even the conditions referred to in the orders. However, the Court proceeded to hold that, assuming the conditions were incorporated into the purchase orders, their forum-selection clause was still too ambiguous to merit enforcement. The clause was drafted in German, but the English translation of the clause provided to the Court stated that the goveming jurisdiction of disputes arising out of the contract was a German city rather than Germany itself, and failed to mention a specific judicial tribunal. Additionally, the Court noted that the English translation of the clause did not preclude the institution of a suit outside Germany, and was therefore not an exclusive forum selection clause of the sort considered by the Supreme Court of Canada in Z.I. Pompey Industrie v. ECU-Line N.V.," but presumably only a "concurrent" forum selection clause. The Court anchored its decision to disregard the forum selection clause on the ground that its wording and application were too "unclear," and did not make reference to the prejudice that might accrue to the Third Party in the event that the clause was enforced (notwithstanding that the trial judge relied heavily upon the fact that the Third Party's action was in danger of being barred by a limitation period in Germany in declining to strike the Third Party's service ex juris order). ${ }^{\text {th }}$

\section{COMMENTARY}

The decision in Alliance suggests that, despite recent trial judgments to the contrary, concurrent forum selection clauses will be given less weight than exclusive forum selection clauses. It is also a clear reminder that, regardless of the ordinary need to demonstrate "strong cause" why a forum selection clause should not be enforced, the validity of a forum selection clause (like any contractual provision) is subject to a threshold inquiry into its meaning and application. In light of Alliance, parties would therefore do well to insert exclusive and unambiguous forum selection clauses directly into the agreements which such clauses are intended to govern.

\section{B. Presayterian ChURCH OF SUDAN V. TALISMAN ENERGY INC.}

\section{BACKGROUND}

The international scope of oil and gas activities creates a heightened potential for liability resulting from operations conducted in foreign countries. This potential has been 
considerably amplified through the rediscovery of the Alien Tort Claims $A c r^{49}$ by the American class actions bar. The $A T C A$ entitles a foreign plaintiff to bring an action in the United States against a foreign defendant in respect of actions committed in a foreign jurisdiction. The following decision suggests that $A T C A$ class actions against Canadian oil and gas corporations for alleged human rights abuses in under-developed countries are likely to assume an increasing prominence in the future.

\section{FACTS}

The plaintiffs, a Sudanese church and various current and former residents of Sudan, commenced a class action in the United States under the $A T C A$ against the Sudanese government and the defendant oil company. The plaintiffs claimed that the defendant corporation had been complicit in numerous alleged human rights abuses perpetrated by the Sudanese government upon its non-Muslim population by virtue of the oil exploration and extraction activities carried out by one of its African subsidiaries. They sought to examine three former officers and employees of the defendant (the Respondents) who were resident in Alberta for the purposes of pre-certification discovery, and obtained letters rogatory from the New York District Court that was seized of the American proceedings. The New York District Court also granted a parallel request for letters rogatory against three former employees of the defendant who were resident in Ontario.

The plaintiffs brought an application to enforce the letters rogatory in the Alberta and Ontario courts. ${ }^{50}$ The Respondents objected on the grounds that the plaintiffs had not satisfied the test for the enforcement of letters rogatory in Alberta. They further argued that the underlying action was contrary to Canadian public policy by virtue of the fact that a diplomatic note (the Diplomatic Note) had been sent by the Canadian embassy in Washington, D.C. to the United States Department of State, which criticized the reach of the $A T C A$ and expressed concerns that it had created a "chilling effect" upon Canadian corporations wishing to do business in Sudan. A third objection, based upon the fact that the Respondents were not parties to the American proceedings, was not seriously pursued at the application.

\section{DECISION}

Justice LoVecchio began his analysis of the Respondents' public policy objection by noting that public policy could, in certain circumstances, constitute a legitimate basis for declining to enforce letters rogatory, and referred to the following statement by Dickson C.J.C. in Zingre v. The Queen:

[T] he courts of one jurisdiction will give effect to the laws and judicial decisions of another jurisdiction, not as a matter of obligation but out of mutual deference and respect. A foreign request is given full force and corporate defendants have been brought against mining and oil companies": sec Gregory G.A. Tzeutschler, "Corporate Violator: The Alien Tort Liability of Transnational Corporations for Iluman Rights Abuses Abroad" (1999) 30 Colum. H.R.L. Rev. 359 at 378.

so The proceedings in respect of the Ontario letters rogatory are found in Presbyterian Church of Sudan v. Taylor (2005), 256 D.L.R. (4th) 750 (Ont. Sup. Ct. J.). 
effect unless it be contrary to the public policy of the jurisdiction to which the request is directed ... or otherwise prejudicial to the sovereignty or the citizens of the latter jurisdiction. ${ }^{51}$

He then acknowledged that the Supreme Court of Canada had declined to enforce letters rogatory on the basis of public policy concerns in GulfOil Corp. v. Gulf Canada Lid. ${ }^{52}$ since the request for production in that case was in respect of documents whose disclosure was prohibited by certain regulations issued under the Atomic Energy Control Act. ${ }^{53}$ However, LoVecchio J. proceeded to draw a distinction between the Diplomatic Note and the regulations at issue in Gulf, stating:

What is requested here is information about how Talisman may or may not have conducted its business affairs in Sudan. That is hardly the stuff of the Alomic Energy Control ACt (Canada). Furthermore, the Diplomatic Note suggests the Canadian government is withholding trade suppon for Sudan. So, to the extent the proceedings before the United States District Courts may be seen as having a chilling effect on Canadian companies carrying on business in Sudan, it would seem to be in synch with Canadian public policy and not contrary to it. 54

In the result, LoVecchio J. held that enforcement of the letters rogatory was not contrary to public policy. He therefore allowed the application in part, finding that some of the proposed examination topics satisfied the test for the enforcement of letters rogatory, but that certain others were irrelevant to the New York action.

\section{COMMENTARY}

The decision here is similar to the decision in the parallel Ontario application brought by the American plaintiffs. .s Taken together, these two judgments are a clear indication that letters rogatory issued during American lawsuits brought by foreign plaintiffs against foreign defendants in respect of foreign conduct do not violate Canadian public policy. However, what is not addressed in either case is the question of whether, irrespective of the fact that letters rogatory issued in relation to an $A T C A$ proceeding may not be contrary to Canadian public policy, such international requests for assistance may still be contrary to the deeper idea of comity itself. ${ }^{36}$ As Dickson C.J.C. noted in Zingre, it is not upon public policy, but rather "upon [the] comity of nations that international legal assistance rests." although Zingre confirms that contravention of public policy is one exception to the enforcement of letters rogatory, Zingre logically implies that requests for international legal assistance may also be denied where the very basis for their enforcement (i.e., comity) is

[1981] 2 S.C.R. 392 al 401 [Zingre].

[1980] 2 S.C.R. $39[\mathrm{Gul} / \mathrm{f}$.

R.S.C. 1970 . c. A-19.

Supra note 48 at para. 33.

Supra note 50 at paras. $25,39-44$.

The Ontario court did consider and reject the argument that a Canadian court should inquire into the validity of the jurisdiction asserted by the foreign court in letters rogatory applications, although failed to seriously analyze why the comity issues which might compel such an inquiry are irrelevant to the enforcement of letters rogatory (ibid. at paras. 25,43 ).

Supra note 51 at 401 . 
itself absent. Further, in Tolofson $v$. Jensen, ${ }^{54}$ the Supreme Court of Canada indicated that unduly extra-territorial actions by a foreign government would likely be offensive to comity:

It seems to me self evident, for example, that State $A$ has no business in defining the legal rights and liabilities of citizens of State B in respect of acts in their own country, or for that matter the actions in State B of citizens of State $C$, and it would lead to unfair and unjust results if it did. ${ }^{59}$

It is therefore submitted here that, however laudable the goal of the $A T C A$ in seeking to prevent human rights abuses in foreign countries, it represents a clear attempt by State $A$ to define the legal rights and liabilities of citizens of State B in respect of their actions in State $\mathrm{C}$, and that the letters rogatory at issue in Sudan should therefore have been rejected as inconsistent with the doctrine of comity.

\section{Castillo v. CasthLlo \\ I. BACKGROUND}

Many oil and gas disputes adjudicated within Alberta are often governed by the substantive law of another province or country. This decision clarifies the limitation periods that are applicable to such disputes, and has important ramifications for the constitutional authority of provincial legislatures to enact statutes that limit rights created by other jurisdictions.

\section{FACTS}

The plaintiff wife was injured while she was a passenger in a car being driven by her defendant husband in California. The plaintiff brought an action against the defendant in Alberta two years less one day after the date of the accident, thus falling within the time ordinarily required to commence a civil claim in s. 3(1)(a) of the Alberta Limilations Act. ${ }^{61}$ However, the claim was subject to a one year limitation period under California law, and the defendant brought an application alleging that the plaintiff's claim was prescribed by the foreign limitation period. The Court of Queen's Bench and Court of Appeal each held that the plaintiff's claim was barred by the California limitation period, even though s. 12 of the Limilations Act provides that:

The limitations law of the Province shall be applied whenever a remedial order is sought in this Province, notwithstanding that, in accordance with conflict of law rules, the claim will be adjudicated under the substantive law of another jurisdiction. ${ }^{62}$

[1994] 3 S.C.R. 1022 [Tolofson].

Ibid. at 1052. See also Unifund Assurance Co. v. Insurance Corp. of British Columbia, $2003 \mathrm{SCC} 40$, [2003] 2 S.C.R. 63 at para. 59.

2005 SCC 83, [2005] 3 S.C.R. 870 [Castillo].

Supra note 4.

Jbid., s. 12. 
The plaintiff appealed to the Supreme Court of Canada, challenging the constitutional validity of s. 12 in light of the fact that limitation periods were declared matters of substantive law in Tolofson. ${ }^{63}$

\section{DECISION}

In a brief judgment, the Court held that s. 12 and Tolofson were not inconsistent, since a province may validly enact legislation that has intra-territorial effects upon extra-territorial rights under s. 92(14) of the Constitution $\mathrm{Acl}, 1867 .{ }^{64}$ However, the Court also held that although $\mathrm{s} .12$ can validly impose a shorter Alberta limitation period upon a foreign cause of action, it cannot revive a foreign cause of action that has already expired pursuant to its own substantive law. Justice Bastarache, in a dissenting judgment, would have found s. 12 unconstitutional.

\section{COMMENTARY}

Castillo stands for the proposition that any proceeding initiated in Alberta that is governed by the substantive law of a foreign jurisdiction will be barred by the shorter of the foreign and Alberta limitation periods.

\section{CONTRACTS}

\section{A. ATCO ELECTRIC LTD. V. ALBERTA (ENERGY AND UTHLITIES BOARD) ${ }^{65}$}

\section{BACKGROUND}

Most disputes between parties are resolved by means of settlement agreements. At its heart, this case concerns the proper interpretation of certain settlement agreements, although there are also aspects of this case that concern the role of the Alberta Energy and Utilities Board (AEUB or the Board) in the process of approving negotiated settlements, the function of the AEUB in the restructured electricity market, and the deference that should be paid to AEUB decisions in this context. The case highlights the fact that settlement agreements are subject to the same rules of interpretation as are other contracts, and that neither the AEUB nor the court will intercede to save parties from the bargains they expressly make.

\section{FACTS}

This was an appeal from the AEUB concerning ATCO Electric Ltd.'s (ATCO's) entitlement to receive carrying costs on deferral accounts pursuant to negotiated settlement agreements. One of the key elements of the Alberta government's plan to restructure the electrical industry in the mid-1990s was that a utility would be allowed to negotiate an agreement, or negotiated settlement, with its customers rather than proceeding through to a hearing before the AEUB. The Board was to maintain a role in the process by issuing rules 
to facilitate and encourage negotiated settlements, and by approving such settlements. According to the relevant statutes, no negotiated settlement will be effective unless and until it is approved by the AEUB. In order to be approved, the AEUB must be satisfied that the settlement is in the public interest.

In this appeal, ATCO argued that the Board erred in its interpretation of certain negotiated settlements to which ATCO is a party. It was argued that the Board should have interpreted the negotiated settlements so as to permit ATCO to claim carrying costs on deferral accounts for the year 2000 (the amount of which had been settled). ATCO also contested the amount of carrying costs determined by the Board for the years 2001 and 2002, which were smaller than what ATCO had claimed.

\section{DECISION}

The Alberta Court of Appeal upheld the refusal by the AEUB to include carrying costs on deferral accounts. Although the negotiated settlements required approval of the Board, they were still contracts that were binding on the signatories, subject to a right of withdrawal, which was not exercised in this case. Since the settlements were contracts, the Court determined that they should be interpreted in accordance with the objective of contractual interpretation, which is to ascertain the parties' intentions having regard to the relevant background context known to the parties. This analysis should be objective and focused on what a reasonable person would infer from the words used. In conducting the analysis, the entirety of the contract must be considered.

Applying these principles to the interpretation of the settlements, the Court noted that none of the clauses in the agreements contemplated the payment of interest or carrying costs, nor did they set out a method for calculating interest and carrying costs. Instead, each merely contemplated a one-time adjustment at the end of the year based on the balance of the deferral amount. Thus, the Court agreed with the Board that the terms of the settlement agreements could not be interpreted as entitling ATCO to recover carrying costs for the year 2000.

ATCO argued that if the Court found that the settlements were silent as to ATCO's entitlement to recover carrying costs, ATCO should not be prevented from claiming them now. This argument rests on the theory that silence means that there has not been settlement of the issue. The Court rejected this argument. The settlement agreement contained a clause acknowledging that except as explicitly exempted, the setllement covered all issues between the parties. Since the issue of carrying costs was not explicitly exempted from the settlement, the Court concluded that carrying costs must have been included in the agreement and ATCO had no right to pursue a claim to them now. The Board's interpretation of the settlement agreements was therefore not only reasonable, but also correct.

In the alternative, ATCO submitted that if it was not entitled to carrying costs for the year 2000 , then the AEUB should not have approved the negotiated settlements. To do so, ATCO argued, would not be in the public interest. The "public interest" is not a static concept. Rather, it varies according to circumstance and context, including the legislative framework in effect. In light of the present deregulation of the electricity market in Alberta, the Court 
found that when the Board is called upon to determine whether a negotiated settlement is in the public interest, the AEUB need only consider the interest of the rate-paying public. The Board is not entitled to consider the interest of the utility. While this is a departure from the historic requirement that the Board consider the interests of both parties, the Court listed several reasons why this interpretation of the public interest was appropriate. For example, when the AEUB is presented with a negotiated settlement, it should be entitled to assume that what the utility has negotiated and agreed to is in its best interests. Similarly, the Board is not obligated by statute to confer on a utility a better deal than it asks for, and a utility should not be permitted to resile from its representation to the Board that the settlement is fair and reasonable from the utility's perspective.

\section{COMMENTARY}

In reaching its decision, the Court was asked to determine the appropriate standard of review for the interpretation of the settlements. Applying the factors set out in Pushpanathan, ${ }^{66}$ the Court found that the role of the AEUB in regulating the electric energy industry and the wide grant of discretion given to the Board by the legislature suggested a more deferential standard; however, the nature of the question (a question of law involving considerable importance to the industry) and the court's expertise relative to the Board's with respect to contractual interpretation suggested a less deferential standard. The Court therefore determined that the appropriate standard of review was one of reasonableness. As to the methodology used by the Board to calculate the carrying costs for 2001 and 2002, the Court determined that this question was subject to the standard of patent unreasonableness.

\section{B. PLAS-TEX CANADA LTD. V. DOW CHEMICAL OF CANADA LTD. ${ }^{67}$}

\section{BACKGROUND}

Parties to contracts often try to assign responsibility for potential liability by way of exclusion clauses or limitations of liability clauses. This case demonstrates that such attempts to assign liability cannot go so far as to avoid liability for the very essence of the agreement.

\section{FACTS}

Dow Chemical of Canada Lid. (Dow) had sold resin to two plaintiffs pursuant to sales of goods agreements. It had no contracts with the other plaintiffs. Dow knew that the resin was not suitable for manufacturing natural gas pipe, and also knew that the plaintiffs would use the resin to manufacture pipe to transport natural gas. Rather than wam the plaintiffs of the problem, Dow chose to sell the resin under a contract that purported to limit its liability.

The pipe failed and natural gas escaped. The plaintiffs were forced to undertake major repairs. The resulting cost of the repairs, loss of reputation, and loss of customers ultimately forced the plaintiffs into bankruptcy. (It is not clear from the judgment whether this action 
was commenced by a trustee in bankruptcy for the benefit of the plaintiffs' creditors, but that is likely the case.)

\section{DECISION}

At trial, Dow was found liable in tort to all plaintifrs, and in contract to the two plaintiffs with whom it had a contract. On appeal, the trial decision was upheld.

With respect to the contract action, the trial judge found that Dow had fundamentally breached the contract by providing resin that was completely unsuitable for use as a natural gas pipeline. Dow did not appeal this finding. Dow submitted, however, that the trial judge had erred in finding that the limitation of liability clauses contained in its written contracts with certain plaintiffs were not enforceable. Dow's principal argument in this regard was that limitation of liability clauses should only be deemed unenforceable where there is a grievous impairment of bargaining power, or other instances of unfairness or unreasonableness between the parties. Dow submitted that those circumstances did not exist in this case. The Court of Appeal agreed that, in Alberta, the general rule is that contracts should be enforced regardless of the stringency of their limitation of liability clauses. This is so because parties require certainty that the contractual terms they negotiate will be legally enforceable. This principle, however, is subject to the caveat that a court will not enforce a limitation of liability clause in favour of a party that has engaged in unconscionable conduct. As the Court stated, "a party to a contract will not be permitted to engage in unconscionable conduct secure in the knowledge that no liability can be imposed upon it because of an exclusionary clause. $" 68$

The Court found that Dow's conduct was unconscionable, since it knew that defects in its product would cause pipe manufactured by it to fail. This was made more grievous by the fact that Dow also knew that the pipe would be buried in the ground and used to supply natural gas throughout rural Alberta. As the Court noted, anyone would know that the cracking of such a pipe could cause danger to persons and property. As a result of the finding of unconscionability, Dow was not permitted to rely on the limitation of liability clause contained in the two contracts in question.

\section{COMMENTARY}

Dow strenuously objected to the respondents recovering for loss of profits. In upholding the award for loss of profit, the Court relied on existing authorities for awards of loss of profit and materials in contract. Although the award in this case was decided in tort, the Court held that the measure of damages for loss of profit should be the same as if the case was decided in contract, which is consistent with previous statements of the Supreme Court of Canada in cases concerning concurrent liability in tort and contract. ${ }^{69}$

ny On 28 April 2005, the Supreme Court of Canada dismissed Dow's application for leave to appeal: [2004] S.C.C.A. No. 542 (QL). 


\section{EAGLE RESOURCES LTD. V. MACDONALD ${ }^{70}$}

\section{BACKGROUND}

In the sale of shares or assets, vendors often warrant that they have made available to the purchaser all relevant information pertaining to the asset. This case concerns a breach of such a warranty and highlights the fact that the damages resulting from a breach of the warranty may well exceed the sale price of the shares or assets. It is the final chapter in a saga that has been reported upon in previous editions of this update.

\section{FACTS}

The purchaser entered into a contract with the defendant to purchase all of the issued and outstanding shares in the defendant's oil and gas corporation for approximately $\$ 8$ million. The corporation's main asset constituted approximately 40 percent of its total reserves and production.

In the contract, the defendant warranted that there was no fact known to him that might materially and adversely affect the corporation or any of its assets that had not been set out in the contract. Another clause required the defendant to make available all documents pertaining to or affecting those assets. The purchaser was provided with engineering reports effective 1 June 1990 pertaining to all of the corporation's assets (Sproule 90). However, the defendant did not provide it with a revised engineering report effective I June 199 I pertaining to the corporation's main reservoir (Sproule 91) and which indicated that the reservoir was smaller than previously believed and that production would be considerably less than predicted in Sproule 90. The purchaser sued.

\section{DECISION}

At the first trial, the judge found that that the purchaser had not relied on Sproule 90 , and therefore no damages could be established.

On appeal from the first trial judgment, the Court of Appeal found for the purchaser. Whether or not the purchaser relied on Sproule 90 was irrelevant to the measure of damages in contract. What was relevant was that a warranty had been given and that the warranty was breached. A new trial was ordered to quantify the damages pursuant to a formula established by the Court of Appeal. That formula was to determine the value of the corporation's assets calculated on the basis that Sproule 90 was complete and correct, minus the value of the assets calculated on the basis that Sproule 91 was complete and correct.

At the damages trial, expert evidence indicated that, on a strict reading of the formula set out by the Court of Appeal. Eagle Resources Ltd.'s (Eagle's) damages would be approximately $\$ 14$ million. The damages trial judge was concerned that the formula 
prescribed by the Court of Appeal would put Eagle in a better position than it would have been in but for the breach. Consequently, he assessed Eagle's damages at \$3,488,000.

Eagle appealed the damage assessment on the ground that the damages trial judge failed to apply properly the formula prescribed by the Court of Appeal.

The Court of Appeal again ruled in favour of Eagle and held that the damages trial judge had incorrectly applied the formula previously set out by the Court of Appeal. The appeal was allowed and an award of $\$ 9,470,000$ was substituted.

The Court emphasized that its formula directed that damages should be the value of the assets described in Sproule 90 , calculated on the basis that it is complete and correct, minus their value calculated on the basis that Sproule 91 is complete and correct. The Court acknowledged that it did not, in its previous formula, prescribe the methodology for determining the value of the assets, and it was open to the damages trial judge to make that determination. In doing so, however, the damages trial judge was still required to make a separate determination of value based on each of Sproule 90 and Sproule 91.

The damages trial judge did not do this. Instead, he applied a single barrels of oil equivalent (BOE) value to the difference in remaining recoverable reserves between Sproule 90 and Sproule 91, a method that the Court of Appeal found necessarily presumed that one of either Sproule 90 or Sproule 91 was incorrect. The Court of Appeal further found that the damages trial judge had erred by considering information contained in the production records and other documents that were provided to the purchaser. By doing so, he disregarded the Court's direction that each of the Sproule reports should be treated as complete and correct, and that what Eagle may or may not have known outside the contract should be treated as irrelevant.

\section{COMMENTARY}

Previous chapters in this saga are of greater importance to the oil and gas industry, particularly vis-à-vis the Court of Appeal's formula for the calculation of damage for breach of warranty in instances in which important documents (in this case, engineering reports) are withheld from a purchaser. That formula has twice been approved by the Court of Appeal and on two occasions leave to the Supreme Court of Canada was denied. This chapter of the case is significant because it demonstrates that the Court of Appeal will require that lower courts assessing damage awards strictly comply with any formulae it sets out for calculating damages. Despite the fact that a trial court may disagree with the formula determined by the Court of Appeal, the trial court may not substitute its own formula. 


\section{NORTH CALGARY COMMUNITY CHURCH V. 510207 ALBERTA LTD. ${ }^{71}$}

\section{BACKGROUND}

In contracts concerning land, courts typically require written agreements. This case demonstrates the need for clarity in the written agreement as to the intentions of the parties, rather than external evidence. It also discusses the clements that must be found in an option contract in order to grant an option properly.

\section{FACTS}

Edwin Oman (Oman), the pastor of the North Calgary Community Church (the Church), partnered with Ronald Slater (Slater), a director and shareholder of Caleron Properties Lid. (Caleron), to subdivide and develop a parcel of land in northwest Calgary (the Parcel) to build a new building for the Church. In addition to residential lots, the Parcel was to have a 6.1 acre "family enrichment centre" site, where the new Church would be located. To facilitate the development, Oman and Slater established a company, 510207 Alberta Lid. (510207), which was to acquire the land. Both men subscribed for shares in 510207 and acted as its directors. Oman was appointed President and Slater was appointed Chief Executive Officer and Chief Financial Officer of the company.

In June 1993, 510207 issued a private placement memorandum (the Memorandum) inviting potential investors to acquire shares in the company to facilitate the purchase and development of the Parcel. The private placement closed and the Parcel was purchased by 510207. The development of the Parcel was delayed because the land had significant environmental problems requiring remediation, which reduced the family enrichment site to 4.51 acres. Nevertheless, development of the Parcel progressed and, in 1997, 510207 sold the entire Parcel to Central Park Lodges, with an option to repurchase. The Parcel was then subdivided and resold to 510207 . When a special resolution put to 510207 shareholders to donate the family enrichment site to the Church failed, the Church filed a caveat claiming that it had an option to purchase the family enrichment site for $\$ 125,000$ pursuant to the Memorandum. The Church sued 510207, Caleron, and Slater to enforce the caveat, and sought a summary determination of the caveat's validity.

\section{DECISION}

Although Caleron, Slater, and 510207 never acknowledged that a valid option had been granted to the Church, the summary trial judge proceeded on this basis and characterized the issue as whether the Memorandum satisfied the requirements of the Statute of Frauds. He held that it did, and determined that the option was enforceable. The Court of Appeal held that the summary trial judge had erred in law in failing to consider whether a valid option existed, and elected to make a determination on the issue rather than send the matter back to the Court of Queen's Bench for resolution. The Court held that an option to purchase is a contract and, as such, in order for it to be valid there must be good consideration and 
certainty regarding essential terms such as the parties, the subject matter, and the price. In addition, as stated by the Supreme Court of Canada in Mitsui \& Co. (Canada) Lid. v. Royal Bank of Canada, options generally have the three following characteristics: "(1) exclusivity and irrevocability of the offer to sell within the time period specified in the option; (2) specification of how the contract of sale may be created by the option holder; and (3) obligation of the parties to enter into a contract of sale if the option is exercised." 72

The parties agreed that the only place the option to purchase could be found, if in fact it existed, was within the Memorandum. The Court held that the purpose of private placement offering memoranda generally was to provide prospective investors with full disclosure of the company's past and present business offerings, the shares being offered, and the potential risks of investing. While such a document may describe an option to sell real property to which the issuer is a party, the Court held that "it would be unusual for the offering memorandum to actually grant an offer to purchase real estate to a third party." ${ }^{\text {"73 }}$ However, since this is exactly what the Church was arguing, the Court entered into a detailed analysis of the Memorandum in the context of the Mitsui factors.

The first factor requires that, to be valid, an option to purchase must set out a specified time period for its exercise. The Court found that the Memorandum did not contain such a time period. Second, the option agreement must clearly specify how the option is to be exercised by the option holder. The Court found that while the Memorandum mentioned the possibility of the family enrichment site being sold to the Church, there was no indication of how the Church would trigger the sale, resulting in the Memorandum failing to satisfy the second Mitsui requirement. Finally, the third Mitsui factor requires the option agreement to establish that the parties are compelled to enter into a contract of purchase and sale if the option is exercised. The Court found that since the development project was conditional on a number of further approvals, 510207 would not be in a position to enter into a binding agreement of sale unless these problems were overcome. While the Court acknowledged that it may have been possible to create a valid option despite these contingencies, careful drafting would have been required and "the vague disclosure in the offering memorandum did not accomplish this." 74

In addition, the Court found that two events that occurred after the completion of the private placement confirmed that no valid option existed. First, the environmental remediation required that the land designated for the family enrichment centre had to be reduced from 6.1 acres, as described in the Memorandum, to 4.51 acres. If a valid option had been created by the Memorandum, it would have required amendment to reflect the altered state and reduced size of the optionable parcel. No documentation existed to support such an amendment. Second, when the Parcel was sold to Central Park Lodges in 1997, the sale was consented to by a special majority of 510207's shareholders, including the Church. The sales agreement, consented to by the purported option holder (the Church) contained a representation that there were no options outstanding against the land. 


\section{COMMENTARY}

The significance of this case is the Alberta Court of Appeal's treatment of the Mitsui factors. In Mitsui, the Supreme Court of Canada wrote:

Paul M. Perell, in "Options, Rights of Repurchase and Rights of First Refusal as Contracts and as Inlerests in Land" (1991), 70 Can. Bar Rev. 1, at p. 3, lists the three principal features of an option, all of which are present in clause 32 :

1. exclusivity and irrevocability of the offer to sell within the time period specified in the option;

2. Specification of how the contract of sale may be created by the option holder; and

3. obligation of the parties to enter into a contract of sale if the option is exercised. ${ }^{35}$

The Supreme Court of Canada characterizes these three factors as the "principal features of an option," but does not go so far as to say that they must be present in every case in order for an option to exist. In this case, however, the Alberta Court of Appeal held that, to be valid, an option to purchase "must contain three additional features, set out by the Supreme Court in Mitsui." "It now appears quite clear that for an option to purchase land to be valid in Alberta, the Mitsui factors must be satisfied.

\section{E. KARY INVESTMENT CORP. V. TREMBLAY $Y^{\text {77 }}$}

\section{BACKGROUND}

Many commercial ventures between business partners begin with a jointly-held corporation that is governed by a unanimous shareholders agreement. Often, that agreement is put into place without substantial forethought and is all but forgotten until some form of crisis occurs. While the parties in this case do not appear to have completely ignored their unanimous shareholders agreement, their attention was clearly not overly focused on it, or on the other important corporate documentation that followed.

\section{FACTS}

This case concerns whether a notice under a put provision was invalid because it was not served upon the proper persons. While both parties agreed that the requirements of the contract must be strictly observed when exercising notice under a put provision, there was an issue with respect to who was a shareholder for the purpose of serving the notice.

Kary Investment Corp. (Kary) and the defendant Marcel Tremblay (Tremblay) were shareholders of a closely held corporation (the Corporation), which was governed by a unanimous shareholders agreement (the USA). The USA contained a term (the Put) stipulating that any shareholder other than Tremblay who wished to sell any or all of its shares in the Corporation could give notice in writing to all other sharcholders advising them 
that it wished to do so, offering to sell its shares to the other shareholders at a value fixed in the USA.

Approximately three months after the USA was executed, a Waiver and Novation Agreement (the WNA) was executed. In addition to waiving Kary's right of first refusal, the WNA novated five other persons into the USA as new shareholders (the Contested Shareholders) pursuant to share subscriptions. Despite receipt of the share subscriptions and monies paid, no directors' resolution was passed authorizing the issuance of shares to the Contested Shareholders. Moreover, no share certificates were ever issued in their names and their names were never added to the shareholders' registry in the Corporation's minute book.

Kary subsequently served a notice under the Put (the Put Notice) on Tremblay, who was the only other sharcholder recorded in the shareholder registry. The Put Notice was also addressed to the other parties who had subscribed and paid for shares, although they were not served with the Put Notice. Tremblay refused to honour the Put Notice and Kary commenced an action under the USA for the value of the shares. The trial judge concluded that there is no requirement that a shareholder be a "registered" shareholder in order to benefit from rights under a USA. Thus, she dismissed Kary's action on the ground that by not serving the Put Notice on the Contested Sharcholders, Kary had failed to comply strictly with the terms of the Put. Kary appealed.

\section{DECISION}

On appeal, Kary argued that the WNA was executory and not binding on it due to incomplete subscription and payment by all parties. The Court relied on Halsbury's for the proposition that a contract is executory "if anything remains to be done under it by any party." "78 The Court found that given the steps that were left undone, it was clear that the WNA was executory. According to the Court, however, the fact that a contract is "not fully performed does not make it unenforceable. While failure to perform services or pay for goods or other consideration may give rise to an action for specific performance or damages, it does not render a contract void." 79 Thus, while no directors' resolutions had been passed authorizing the issuance of shares, no share certificates had been issued and no new names had been added to the shareholder registry at the time Kary attempted to serve its Put Notice, the Court found that the Contested Shareholders, as well as Kary and Tremblay, were fully bound by the terms of the WNA with respect to both its rights and its obligations. The Court therefore dismissed this ground of appeal.

In addition, Kary argued that since the WNA was a multi-party agreement, it was essential that each party be identified exactly. It further argued that the trial judge had failed to consider a term of the WNA that specifically prohibited amendment unless agreed to by all of the parties, pointing out that: (1) one of the Contested Shareholders had unilaterally altered the signature page of the WNA by substituting the name of his private company in place of his own name, which company had delivered and paid for the share subscription; (2) a 
second share subscription was received from and paid for by the private company of another party to the WNA; and (3) a third share subscription was received from and paid for by the wife of a party to the WNA. Finally, Kary argued that pursuant to s. 50(1) of the Alberta Business Corporations $A c t,{ }^{80}$ a corporation need only give notice to the registered owners of its shares, and a shareholder should not be held to a higher standard.

The Court adopted the test for materiality of identity set out by Fridman in the The Law' of Coniract in Canada, which is "whether there was some personal factor or feature about the actual contracting party (or about the principal) which made the actual contracting party attractive and desirable as a contracting party." sending out notices must be governed by the share register, registration does not govern the substantive rights of shareholders to purchase shares from each other."

The Court distinguished Lake \& Co. v. Calex Resources $L 1 d .^{83}$ on the ground that that case involved the interpretation of s. $184(4)$ of the $A B C A$, a clause that specifically limited the right of dissenting shareholders to make a claim to shares registered in the name of the dissenting shareholder.

In his concurring opinion, Berger J.A. considered the meaning of the term "shareholder." He noted that while "[c]orporate legislation in Alberta codifies and clarifies many of the incidences of shareholding that establish several of the rights and remedies available to persons who are shareholders ... [the] legislation ... does not define 'shareholder' or determine the basic (or any) criteria for being or becoming a 'shareholder'." 84 Instead, the determination of who is a shareholder is a matter of contract. Berger notes that there are several meanings that can be given to the term "shareholder": persons who have subscribed for and been allotted shares, but whose names have not been entered into the registers of the corporation; persons who have subscribed for shares, but have not yet been allotted them; persons who have subscribed for shares, but have not yet paid for them; and, finally, persons "who have entered into an agreement to purchase shares, or who have otherwise acquired an equitable title to those shares, but to whom the formal transfer of those shares is still to be made." ${ }^{85}$ Noting that a person may be a shareholder for some purposes but not for others, Berger J.A. stated that when discussing a rule of law relating to a shareholder of a corporation, it is important to clarify the type of shareholder who is contemplated by the rule.

In addition, Berger J.A. expressly agreed with the trial judge that "there is no requirement that a shareholder be a 'registered' shareholder in order to benefit from rights under a unanimous shareholders agreement." 86 He noted that in Gordon v. Gaby," "a unanimous Supreme Court of Canada found that while a company is undoubtedly justified in regarding

R.S.A. 2000 , c. B-9 $[A B C A]$.

Kary, supra note 77 at para. 28, quoting G.H.L. Fridman, The Law of Contract in Canada, 4th ed. (Turonto: Carswell, 1999) at 282.

Kary, ibid al para. 41.

(1996), 187 A.R. 128 (C.A.).

Supra note 77 at para. 50.

lbid. at para. 51, citing Kevin Patrick McGuinness, The Law and Practice of Camadian Business Corporations (Toronto: Butterworths, 1999) at 835-36.

Kary, ibid. at para. 61 .

[1966] S.C.R. 527. 
its shareholders register as its official list of sharcholders, for example, for the purpose of mailing notices and dividends, such administrative considerations should not have any part in governing a matter of substantive rights." ${ }^{\text {B8 }}$

\section{COMMENTARY}

The Court obviously adopted a substantive and purposive approach to enforcing shareholders' rights. It is submitted that this was the correct approach to take, and that the Court came to the correct result; however, this case is proof that parties who neglect to pay attention to mundane but important details, such as ensuring that a unanimous shareholders agreement contemplates the full spectrum of its potential parties and properly updating a corporate minute book, can find themselves in a lengthy and expensive legal proceeding that could have, and should have, been avoided.

\section{Creditors' Rights}

\section{A. CRYSTALLINE INVESTMENTS LTD. V. DOMGROUP LTD. ${ }^{\mathrm{g9}}$ \\ I. BACKGROUND}

It is common practice for oil and gas industry participants to assign leasehold interests in real estate to third parties. Although the insolvent assignee of such an interest is entitled to repudiate its obligations to the lessor under the Bankrupicy and Insolvency Act, ${ }^{90}$ the following decision of the Supreme Court of Canada is a clear waming that assignors will remain liable to lessors notwithstanding such repudiation.

\section{FACTS}

The defendant was the original tenant in a lease of real property entered into with the plaintiff lessor. The lease provided that the defendant was to remain primarily liable to the plaintiff for its obligations under the lease regardless of any assignment or sublease. The defendant assigned the lease to a third party, which subsequently became insolvent, and repudiated the lease through its trustee under s. $65.2(1)$ of the $B I A$, which provides that:

At any time between the filing of a notice of intention and the filing of a proposal, or on the filing of a proposal, in respect of an insolvent person who is a commereial lessee tenant under a lease of real property or an immovable, the insolvent person may disclaim or resiliate the lease on giving thirty days notice to the lessor in the prescribed manner, subject to subsection (2).

The plaintiff notified the defendant of the assignee's repudiation, and asserted its right to be paid the remaining rent directly from the defendant. When the defendant refused to tender the outstanding monies, the plaintiff brought a summary judgment application, which was 
dismissed at first instance via reliance on Cummer-Yonge Investments Lid. v. Fagot, ${ }^{91}$ a decision that held that the statutory termination of a lease by two tenants extinguished their guarantor's liability to the lessor. The Ontario Court of Appeal reversed this finding, and the defendant appealed to the Supreme Court of Canada.

\section{DECISION}

The Court noted that the defendant did not plead that its obligations under the lease were extinguished via any common law doctrine (such as surrender), and confined its analysis to the question of whether a repudiation under s. 65.2 of the $B I A$ was sufficient to obviate an assignor's liabilities under a commercial tenancy respecting real property. In finding that $s$. 65.2 did not have this effect, the Supreme Court of Canada overruled Cummer-Yonge, and held that both original lessees, and guarantors of lessees, would remain primarily liable to lessors subsequent to a s. 65.2 repudiation. However, the Court accepted that original lessees (and, presumably, guarantors) ${ }^{92}$ could still make an unsecured claim against the insolvent lessee if the assignment created a contractual indemnity right in favour of the assignor as against the assignee.

\section{COMMENTARY}

Crystalline stands for the proposition that a third-party guarantor of the obligations of a lessee of real estate under a lease who later chooses to assign its tenurial interests under that lease faces a continued risk of primary liability to the lessor even after the lessee's bankruptcy. Prospective guarantors of such obligations would therefore do well to consider requiring security for any contractual indemnity rights that they plan upon extracting from the assignee or guaranteed party.

\section{B. RESTELCO INC. ${ }^{93}$ \\ 1. BACKGROUND}

The Companies ' Creditors Arrangement $A c t^{44}$ vests a uniqucly broad remedial power in courts that supervise corporate restructurings commenced under the $A c t$. This decision represents a retreat from the unfettered jurisdiction often assumed by $C C A A$ courts, and sets clear limits upon the ability of a judge to intervene in the internal affairs of a corporation that is subject to $C C A A$ proceedings.

\section{FACTS}

The appellants were two persons associated with corporations that had obtained a significant shareholding in Stelco Inc. (Stelco) while it was engaged in a restructuring under the $C C A A$. Pursuant to a unanimous decision of the Stelco board, the appellants were 
appointed as directors of Stelco. The respondents, who represented various Stelco cmployees, brought a successful application to remove the appellants from the board, alleging that the appellants were likely to use the restructuring process as a vehicle for maximizing shareholder value in Stelco, and not consider proposals that were also favourable to the employees. In allowing the application, Farley J. held that his authority to do so issued from both the Court's "inherent jurisdiction," and the statutory "discretion" conferred upon courts under s. 11 of the CCAA. The appellants appealed to the Ontario Court of Appeal, alleging that Farley J. had neither the inherent jurisdiction nor the statutory discretion to remove the directors, and further alleging that, assuming such authority did exist, it had nevertheless been exercised improperly.

\section{DECISION}

The Court of Appeal, per Blair J.A., overturned Farley J.'s ruling, and held that a CCAA court has neither the inherent jurisdiction nor the statutory discretion to order the removal of directors from a corporation that is involved in a restructuring (although accepted that this authority exists as part of the oppression remedy). The Court further held that, even assuming such a jurisdiction or discretion did exist, Farley J. erred in not deferring to the business judgment of the Stelco board, and in applying the administrative law test for a reasonable apprehension of bias when ordering the removal of the directors.

In holding that Farley J. did not have the inherent jurisdiction to make the impugned order, Blair J.A. stated that:

I do not mean to suggest that inherent jurisdietion can never apply in a $C C A A$ context. The court retains the ability to control its own process, should the need arise. There is a distinction, however - difficult as it may be to draw - between the court's process with respect to the restrucluring, on the one hand, and the course of action involving the negotiations and corporate actions accompanying them, which are the compuny 's process, on the other hand. The court simply supervises the latter process through its ability to stay, restrain or prohibit proceedings against the company during the plan negotiation period "on such terms as it may impose". Hence the better view is that a judge is generally exercising the court's statutory discretion under s. II of the Act when supervising a CCAA proceeding. The order in this case could not be founded on inherent jurisdiction because it is designed to supervise the company's process, not the court's process. ${ }^{95}$

In further holding that Farley J. did not have the statutory discretion to order the removal of the directors, Blair J.A. described the nature of the s. 11 CCAA discretion as follows:

What the court deses under s. 1$]$ is to establish the boundaries of the playing field and act as a referee in the process. The company's role in the restructuring, and that of its stakeholders, is to work out a plan or compromise that a sufficient percentage of creditors will accept and the cour will approve and sanction. The coporate activities that take place in the course of the workout are governed by the legislation and legal principles that normally apply to such activities. In the course of acting as a referec, the court has great lecway ... "to make order[s] so as to effectively maintain the status quo in respect of an insolvent company while it allempls to gain the upproval of its creditors for the proposed compromise or arrangement which will be to the benelit of both the company and its creditors". But the $s$. II discretion is not open-ended and 
unfettered. Its exercise must be guided by the scheme and object of the $\Lambda$ et and by the legal principles that govern corporate law issues. Moreover, the court is not entilled to usurp the role of the directors and management in conducting what are in substance the company's restructuring aflairs. ${ }^{96}$

Ultimately, because the legislature had already provided a statutory mechanism for the removal of directors under the oppression provisions of the various federal and provincial corporate statutes, and further because "[w]here another applicable statute confers jurisdiction with respect to a matter, a broad and undefined discretion provided in one statute cannot be used to supplant or override the other applicable statute,"97 Blair J.A. held that the statutory discretion implicated in $\mathrm{s}$. 11 of the $C C A A$ does not include a discretion to order the removal of directors from a $C C A A$ corporation.

\section{COMMENTARY}

The decision in Stelco heralds a significant shift away from the unbounded jurisdiction and discretion generally invoked by $C C A A$ courts, and charts a new direction in CCAA jurisprudence. The limitations that Stelco places upon the inherent jurisdiction and statutory discretion of CCAA courts will be a powerful weapon in the armoury of creditors of oil and gas corporations that become subject to $C C A A$ proceedings.

\section{DIRECT ENERGY MARKETING LTD. V. KALTA ENERGY CORP. ${ }^{98}$}

\section{BACKGROUND}

Priority disputes between creditors of joint wellsite operators are a common feature of Canadian oil and gas litigation. This decision illustrates the pitfalls that may prevent such creditors from realizing upon their security where they have failed to conduct the appropriate due diligence.

\section{FACrS}

The appellant was the vendor and designer of seven separator packages used in the development of gas production. It had sold the packnges to a party that was the operator of various well locations that it owned jointly with several other working interest partners. The relationship between the operator and its working interest partners was governed by a farmout agreement that incorporated the 1974 CAPL Operating Procedure and the $1976 \mathrm{CAPL}$ Accounting Procedure for joint operations. The operator sent the separators to the seven well locations but did not pay the invoices tendered by the appellant. Subsequently, the operator and the appellant decided to change the arrangement for the separators from a sale to a lease, and entered into rental agreements respecting them. However, the operator did not obtain the consent of the non-operators to the alteration of the original sale transaction. The operator was subsequently petitioned into bankruptcy by a secured creditor with an interest over all of its property, and the appellant alleged that title to the separators had never passed to the 
operator in light of the rental agreements. As such, the appellant submitted that the separators were not included within the creditor's security. The assignee of the creditor (the respondent) and the working interest partners then brought a successful application for an order that they had priority with respect to the separators, and the appellant appealed.

\section{DECISION}

The Court of Appeal affirmed the lower court's order that the respondent and the working interest partners had priority over the separators. It rejected the appellant's contention that title to the separators had not been transferred to the operator upon the initial sale, noting that there was a common intention to effect a transfer of title subsequent to their delivery. The Court further rejected the appellant's argument that, because the appellant had not paid the manufacturer of the separators at the time of the sale, the appellant itself did not have a sufficient interest over the separators to transfer title to the operator, stating that it represented an attempt "to rely upon [the appellant's] own breach of its covenant to give title,"99 and that "[t]his reasoning, from breach to terms of contract, is backwards." ${ }^{(1)}$ Finally, the Court affirmed the lower court's finding that the CAPL procedures did not enable the operator to transform the sales transaction into a leasehold arrangement in the absence of the working interest partners' consent (notwithstanding that art. 301 of the 1974 CAPL Operating Procedure gave the Joint Operator "exclusive control and management of the exploration, development and operation of the joint lands for the joint account").

\section{COMMENTARY}

Although in most circumstances it may be impractical to do so, trade suppliers and other creditors contracting with wellsite operators should, to the extent possible, confirm that the operator has the authority to bind its working interest partners in prospective security arrangements. At a minimum, every oil and gas trade supplier should be aware of this decision and ensure that any material amendment or other change to a supply contract with an operator is subsequently approved by all of the non-operators.

\section{EMPLOYMENT}

A. WILDE V. ARCHEAN ENERGY LTD. ${ }^{101}$

1. BACKGround

This case involved two employees who sued their former employer, Archean Energy Lid. (Archean), for constructive dismissal as a result of certain letters sent to them by the President and CEO. 


\section{FACTS}

Archean is a privately-held petroleum and natural gas exploration company. The plaintiff, Perry Wilde, is a professional engineer who commenced employment with Archean in 1995, and in 2001 was Archean's Vice-President of Operations. The plaintiff, Donald Schott, is a chartered accountant who commenced his employment with Archean in 1999, and in 2001 was Archean's Chief Financial Officer. Schott and Wilde, together with Larry Parks, Archean's Chief Executive Officer, were in control of the decisions made at Archean and were primarily responsible for its success.

The company entered into a Stock Option Agreement with Wilde and Schott in late June 2001, and Wilde and Schott exercised their options on 10 August 2001. Pursuant to the Stock Option Agreement, the plaintiffs were entitled either to acquire shares of Archean or to be paid the "Cash-Out Value" of their options. "Cash-Out Value" was to be determined based upon Archean's net asset value (NAV). For some time prior to 10 August 2001, Archean had been attempting to sell its operating subsidiaries and had succeeded in selling one, but was not having success in selling the other two. Parks was very disappointed when he learned of the plaintiffs' decision to exercise their stock options at a critical juncture in the sale process, believing that they had opportunistically timed the exercise of their options in the expectation that Archean would be hesitant to adopt an aggressive approach to determining Archean's NAV for the purpose of determining the Cash-Out Value given the likely harmful effect that such value would have on its sale process.

In the first letter dated 4 September 2001, Parks wrote a letter to Wilde and Schott expressing his strong disappointment in their decision and containing, inter alia, the following:

I have indicated to each of you my sincere disappointment and regret that you have taken this step [exercising the options] at a time when I believe we had an agreement and understanding that we would finish what we had collectively started, i.e., the process of selling [the operating subsidiaries] prior to "cashing out". Indeed, I am having the issue of your entitlement to exercise such Options reviewed in light of our mutual agreement and understanding, but your actions leave us no choice but to attempt to determine the appropriate Cash-Out Value if it should turn out that you were entitled to do so ...

You have effectively created a conflict of interest position for yourselves ... even though the disclosure which I am requesting will potentially adversely affect your finaneial interests, I expect you to discharge your duties to the corporation as oflicers to "act honestly and in good faith with a view to the best interests" of the corporation and "exercise the care, diligence and skill that a reasonably prudent person would exercise in comparable circumstances" [language that the learned Trial Judge noted was borrowed from the $A B C A$ ]....

Because of comments which have been made to me or advisors of the corporation I have some concerns about the integrity, accuracy and completeness of the financial statements and existing report [which the learned Trial Judge noted were within the responsibility of the plaintifls]. ${ }^{102}$ 
The plaintiffs responded by letter dated 10 September 2001, saying that they would "use their best efforts to provide material directly affecting the calculations required to establish the NAV as at August 10, 2001." They also wrote:

As a general comment, we are disappointed in the approach and tone taken by Archean expressed in your letter dated September 4th. The letter is clearly accusatory and confrontational and various allegations made are unsupported, un fair and clearly intended to cast aspersions upon our character and the valued service we have provided to this company throughout. Ironically, this approach and the very nature of some of the documents and information requested, indicate that Archcan appears ready to embark upon an approach which will be clearly contrary to the best interests of Archean, and its shareholders, and raises the very real prospect that the value of Archean and its assets, and the value to its shareholders will be significantly devalued. $^{103}$

\section{Parks responded on 14 September 2001:}

Firstly, if my letter of September 4 referred in yours had been intended to be "accusatory and confrontational", or to contain "allegations" or to "cast aspersions upon [y]our character". I would have been far clearcr in doing so. I am sorry that you took those implications from my letter.

...In the current circumstances, it is hardly open to you to make the final determinations of what is, and what is not, relevant to the valuation that needs to be made. It is not sufficient to state that you will use your "best efforts to provide [me] with materials directed effecting [sic] the calculations required to establish the NAV as at August 10, 2001". I expect you to do what you have been asked to do.

Your letter effectively challenges Archean by suggesting that our attempts to determine the proper anount payable to you "will be clearly contrary to the best interests of Archean, and ils shareholders, and raises the very real prospect that the value of Archean and its assets, and the value to its sharcholders will be significantly devalued". I want to say two things about this inflammatory statement:

1. Given your conflict of interest, you are in no position to lecture me what is in the best interests of Archean.

2. One could interpret that you're attempting to take advantage of the fact that we were in "sale mode" to opportunistically time the exercise of your options in the anticipation and expectation that we would be fearful of raising value issues that could have an effect upon the ultimate amount obtained in a salc. ${ }^{104}$

On 14 September 2001, the plaintiffs presented Parks with their calculation of Archean's NAV. The value ascribed by them was $\$ 289.8$ million and would have resulted in an aggregate cash payment to them of over $\$ 11$ million. On 9 November 2001, Archean presented the plaintiffs with its calculation of net asset value at $\$ 148.77$ million (later corrected for mathematical and other errors to $\$ 155$ million; the trial judge determined that the net asset value was actually $\$ 193$ million).

Ibid. (Evidence, Letter from Wilde and Schott to Parks on 10 September 2001, filed in defendant's Exhibit 487). 
By letter dated 16 November 2001, Parks stated:

Wc would recommend heartily that you engage legal counsel on this matter and on the matter of your employment and do so soon.

In relation to your slewardship of the sale process, we are considering whether the over statement of reserves and revenues and understatements of costs, particularly on the properties we had not previously independently reviewed, constitute a breach of your duties to the corporation and caused it damages. The factors contributed to our having unrealistic expectation as to values to be obtained in the sale process ...

We are also considering whether the matters described ... above constitute cause for your dismissal. ${ }^{105}$

The Plaintiffs resigned from their employment and sued for constructive dismissal.

\section{DECISION}

The Alberta Court of Queen's Bench found that Archean had constructively dismissed the plaintiffs. Justice Martin held that Parks' letters "openly called into question the loyalty, [honesty], and integrity of the plaintiffs," and that once Parks did so, their "working relationship which had been so successful and so profitable was over." 10 r Justice Martin stated that although Parks was Archean's CEO, both plaintiffs "were at least his equals professionally and his attacks on their character and reputations [were] under the guise of searching for more reliable information [and] were completely unjustified and insulting."107 In particular, the Court noted "this personal attack was precipitated by the plaintiffs wishing to exercise their contractual rights ... without being professionally vilified and impeached," ${ }^{108}$ notwithstanding that the "timing may have been unfortunate, the process may have been expensive, and it may have been awkward for Parks to explain to Archean's Board how he could have allowed the situation to occur." (1)

In assessing the period of reasonable notice, the Martin J. found that the plaintiffs could have found alternative employment within six to eight months, but damages were assessed on the basis of a 12 month notice period. The Court did not reduce damages for failure to mitigate, accepting the plaintiffs' argument that the lawsuit against Archean was very complex and they were justified spending their time preparing for trial rather than searching for new employment (although Martin J. noted that this was a unique finding based on the significant complexity of the litigation and is not one that he would "normally find attractive or even satisfactory"). ${ }^{110} \mathrm{Finally}$, in an additional finding that underscores Martin J.'s opinion that Parks' conduct toward the plaintiffs in this case was particularly egregious, the Court Exhibit 503).

106 lbid. at para. 26.

103 loid.

108 lbid.

109 lbid.

$110 \quad$ Ibid. at para. 34. 
also awarded a further $\$ 200,000$ to each plaintiff for their claim for "aggravated, even punitive damages" in accordance with Wallace v. Unied Grain Growers. ${ }^{\prime \prime \prime}$

This case is currently under appeal.

\section{COMMENTARY}

This case is important for all employers in Alberta and highlights the potential scope of damages that may be awarded as a result of constructive dismissal. If the Court of Appeal upholds the "Wallace" damages for a claim of aggravated and punitive damages, this will be a unique application of Wallace, where the Supreme Court held that the reasonable notice period in dismissal could be increased where there is bad faith in the manner of termination by the employer.

Perhaps more importantly, it provides a clear reference for counsel advising clients who might be inclined to react aggressively with accusations and vitriol as the Court found Archean's CEO did here. While these facts may represent somewhat of an extreme case, both in terms of the stakes involved and the conduct of some of the partics, if this decision is upheld on appeal it will serve as a form of lighthouse by which labour and employment lawyers can steer their clients who have such inclinations away from the legal shipwreck that might otherwise occur.

\section{B. ALBERTA (HUMAN RIGHTS \& CITIZENSHIP COMMISSION) V. KELLOGG, BROWN \& ROOT (CANADA) CO. ${ }^{12}$}

\section{BACKGROUND}

This case considers drug and alcohol testing in the context of the prohibition on discrimination in the area of employment practices on the grounds of physical and mental disability, contrary to s. 7(1) of the Human Rights. Citizenship and Multiculturalism Act. ${ }^{13}$

\section{FACTS}

The complainant, John Chiasson was offered a position by Kellogg, Brown and Root (Canada) (KBR) as a receiving inspector for a Syncrude upgrader project at Fort McMurray. The offer of employment was made conditional on Chiasson successfully passing a medical and pre-employment drug test. Chiasson completed the drug screening test on 28 June 2002 and reported for work on 8 July 2002 . Less than two weeks later, he was terminated from employment after test results showed the presence of marjuana.

Chiasson filed a complaint with the Alberta Human Rights Commission (AHRC) alleging KBR had discriminated against him on the basis of a perceived mental or physical disability. He also argued that he was not employed in a safety-sensitive position and should not have 
been tested, and that the employer's policy was discriminatory. Chiasson argued that he was a recreational user of marijuana and not addicted to, or dependent on marijuana, and that his marijuana use did not affect job performance.

\section{DECISION}

The Court of Queen's Bench reversed the AHRC panel decision, finding that the employer's pre-employment drug testing constituted prima facie discrimination against a drug-related disability under s. 7(1) of the Human Rights, Citizenship and Multiculrural Act. In arriving at this decision, Martin J. relied heavily on a 2000 decision of the Ontario Court of Appeal, Entrop v. Imperial Oil Ltd., ${ }^{114}$ where Laskin J.A. found prima facie discrimination when an employee was assigned out of his safety-sensitive position after admitting to a previous alcohol addiction, though he had been sober for seven years. In Entrop, Laskin J.A. concluded that the applicable sanctions under the policy before the Court were the same for persons regardless of whether they are drug-addicted or casual users. He therefore concluded that, in effect, both types of persons are discriminated against, either by an actual disability or the perception of a disability, and therefore both were equally entitled to the protections afforded discriminated classes of persons under Ontario's human rights legislation. ${ }^{115}$

Following Entrop, Martin J. then found that although Chiasson was not drug-dependent, he was discriminated against as if he was and that this constituted discrimination on the ground of a perceived disability. Justice Martin found that KBR's policy was not justified under the test established in Meiorin, ${ }^{116}$ as the policy made no attempt at accommodation. Meiorin requires that discriminatory standards must be:

1) adopted for a "purpose rationally connected to the performance of the job";

2) adopted in good faith, in the belief that it is "necessary for the fulfillment of that legitimate work-related purpose"; and

3) reasonably necessary to accomplish that legitimate work-related purpose and that it is "impossible to accommodate individual employees sharing the characteristics of the claimant without imposing undue hardship upon the employer."117

Justice Martin found that while KBR's policy passed the first and second steps of the Meiorin test, it failed the third step, as KBR applied a zero tolerance policy for positive drug tests, coupled with automatic termination and no attempt at accommodation. Justice Martin held that "[t]he Policy is too severe, more stringent than needed for a safe workplace and not sufficiently sensitive to individual capabilities."118 She ordered KBR to cease the contravention of the legislation and to refrain in the future from committing the same or any similar contravention.

(2000), 50 O.R. (3d) I [ [Entrop].

Human Rights Code, R.S.O. 1990, c. H.19.

British Columbia (Public Senvice Employee Relations Commission) v. BCGSEU, [1999] 3 S.C.R. 3 [Meiorin].

lbid. at para. 54.

Supra note 112 at para. 110. 


\section{COMMENTARY}

Chiasson is significant for the oil and gas sector in Alberta as it requires employers to revisit their drug and alcohol testing policies to ensure that they meet the Meorin criteria. This case is the most recent in a series of drug and alcohol testing cases in Alberta, including Alberta (Human Rights \& Citizenship Commission) v. Elizabeth Métis Settlement, ${ }^{119}$ which to date has already gone through several appeals. This decision has been appealed to the Alberta Court of Appeal, and the decision of that Court should ultimately settle the law in this area.

\section{TELUS COMMUNICATIONS INC. V. TELECOMMUNICATIONS WORKERS UNION ${ }^{120}$ \\ 1. BACKGROUND}

The recent labour dispute at Telus has resulted in several new court decisions on picketing that help to understand further how picketing is to be regulated in the new age introduced by the Supreme Court of Canada in R.W.D.S.U., Local 558 v. Pepsi-Cola Canada Beverages (West) $L t d{ }^{121}$ These decisions are important for all employers involved in a labour dispute. The string of Telus cases in both British Columbia and Alberta have further developed the law on several other important matters, including the progress of injunctive relief, the enforcement of injunction orders, the attempt to establish a "two minute rule," and picketing individuals at restaurants, hotels, and homes.

\section{FACTS}

Telus Communications Inc. (Telus) brought an application for an injunction to restrain picketing at the homes of ten employees. Picketers wearing signs walked along the sidewalks in front of various employees' homes, often shouting obscenities and carrying threatening and accusatory signs. The duration of the picketing varied from 15 minutes to approximately two hours.

Telus had previously challenged residential picketing and picketing people at restaurants and hotels in British Columbia. ${ }^{122}$ In that case, the British Columbia Supreme Court determined that Pepsi-Cola did not guarantee a right to follow the vehicles of management personnel to their homes, and that the picketing of homes of Telus employees constituted an unwarranted and unlawful watching and besetting, intimidation, public and private nuisance, and a clear attempt to coerce the employees to breach their contracts with Telus. The picketing of homes was enjoined and the Court also prohibited picketing at hotels and motels where Telus employees were staying, referring to them as "temporary residences," and at restaurants, saying the employees were entitled to take their meals without picketers being present. 


\section{DECISION}

In this case, the Alberta Court of Queen's Bench did not follow the B.C. decision, and said that the Pepsi-Cola decision held that picketing at private residences is legal as long as there is no unlawful or tortious conduct. The Court ordered that residential picketing be limited between 9 a.m. and 4 p.m., ordered there be no contact with children of the Telus employees. no excessive noise, shouting, or swearing, and picketers were required to be at least five feet away from the entrance to or exit from the residence of any Telus employee.

\section{COMMENTARY}

The Supreme Court of Canada's endorsement of picketers handing out leaflets and other non-traditional types of labour dispute communication, and its abolition of the prohibition on secondary picketing, have disturbed the relative calm and reasonable certainty previously enjoyed under statutory and common law regimes for regulating picketing activity. It could easily be argued that unions have claimed greater rights than the courts intended to grant, while employers and third parties have sought greater restrictions and made more expansive claims of what constitutes "wrongful action" than the courts are prepared to recognize. The analysis of what constitutes "wrongful action" is being pursued using traditional legal analysis that seems strained in a labour relations context. As the Supreme Court of Canada noted in Pepsi-Cola, tort law may need some further development in this area, both in finding the elements of the tort in the context of a labour dispute and in determining who is entitled to bring a claim of tortious conduct. In the meantime, all employers need to be aware of the scope of this new-age picketing in their own labour relations, as well as to the implications of labour relations disputes for their customers, suppliers, contractors, and others.

\section{OCCUPational Health aNd SAFety}

\section{A. R. V. ALTAPRo CLEANING \& DISASTER RESTORATION LTD. ${ }^{123}$ \\ 1. BACKGROUND}

The Alberta Provincial Court confirmed the province's tough stance against employers who fail to ensure the health, safety, and proper supervision of employees in the context of a prosecution under the Occupational Health and Safety Act. ${ }^{124}$

\section{FACTS}

Altapro Cleaning and Disaster Restoration Ltd. (Altapro) is in the business of repairing and reconstructing structures damaged by a natural disaster. Its primary source of business is from insurance companies and, at the time the facts giving rise to this case occurred, the company had been in business for over 40 years. 
In this case, Altapro was hired to examine a $4 \mathrm{~m} \times 8.5 \mathrm{~m}$ brick wall erected on two facades of a building. The owners were concerned that the lean of the wall and an emerging gap between the brick wall and the bearing wall of the building might cause the brick wall to collapse. One of the owners of Altapro conducted a visual inspection of the wall, but was unable to see the gap from more than one vantage point. He gave the wall a firm push and concluded that it was secure and that the removal did not require bracing and could be done using a scaffold. One of the employees that carried out the demolition had never demolished a brick wall before and received no particular instruction from Altapro other than an admonition to "be careful." When he used a hammer and chisel to dislodge the bricks, the entire wall collapsed causing the scaffolding to collapse. The employee suffered serious, permanent injuries.

Altapro was charged under the OHSA with four counts of failure to ensure the safety, proper supervision, and competence of one of its workers. In its defence, Altapro argued that it had exercised due diligence and should not be found guilty of any offence.

\section{DECISION}

Altapro was found guilty of three of the four charges. The Court held that the due diligence test requires a determination of what an employer in the position of Altapro should have done to ensure as far as practicable the health and safety of its employee engaged in the removal of the brick wall. In the Court's view, the collapse of the wall was a foreseeable event and Altapro did not take sufficient steps to address the perceived risk. The Court noted that telling workers to "be careful" was not any kind of safety expression specific to this project, but rather a general corporate policy that was not helpful. The visual inspection and push test were not sufficient to establish structural safety and more investigation into the gap was required. The Court also found that the supervisor in question was not competent to supervise because he had no appreciation of the safety issues inherent in the work being undertaken.

\section{COMMENTARY}

Occupational health and safety issues are critical in the oil and gas industry and it is important to recognize the high standards expected of employers to ensure employees are properly trained and supervised and that all reasonable measures be taken to ensure health and safety. This decision reinforces the employer's obligations to conduct a thorough hazard analysis of each work site and to ensure employees receive specific training in how to perform work in a safe manner and to ensure supervisors are competent and safety-conscious. 


\section{ENVIRONMENTAL LAW}

A. R. V. TERROCO INDUSTRIES LTD..$^{12 S}$

\section{BACKGROUND}

This decision of the Alberta Court of Appeal discusses five general principles to be reviewed when sentencing environmental offenders: culpability, prior records and past involvement with authorities, acceptance of responsibility, the degree of damage or harm caused by the offence, and deterrence. The principles articulated will likely have broad application in environmental cases and can be used to provide guidance to parties accused of committing environmental offences to determine the scope of their potential liability.

\section{FACTS}

Terroco Industries Lid. (Terroco) operates a business transporting and handling various gases, acids, and solutions. In May 2000, the newly-appointed office manager at Terroco's Drumheller office was: asked to arrange for the transportation of isopropyl alcohol/ hydrochloric acid and hypochlorite solution. Although told that the two products were not to be mixed, the office manager failed to state the nature of the products and the prohibition on mixing them in the shipping documentation. At the pick-up location, the newly-hired driver, unaware of the mixing prohibition (despite the fact that the containers themselves were properly labelled), mixed the products in the tank of his truck, producing chlorine gas that escaped, seriously injuring another individual and causing short-term damage to a neighbouring property. No clean-up was required as the gas dissipated into the atmosphere.

Thereafter, the driver chose to proceed to the delivery point where, upon unloading the mixture into a well for purposes of an acid wash, some of it spilled on the ground, having eaten through the truck's pumping mechanism. No physical injuries occurred at the well site, and Terroco took immediate responsibility and cleaned up the spill. Terroco also reported the incidents to the appropriate authorities on a timely basis and cooperated with the ensuing investigation.

The gas release and liquid spill led to charges, respectively, under what is now s. $109(2)$ of the $E P E A^{126}$ for releasing or permitting the release into the environment of a substance in an amount, concentration or level, or at a rate of release that causes or may cause a significant adverse effect, and s. 19(a) of the Dangerous Goods Transportation and Handling $A \mathrm{Ct}^{127}$ for handling, offering for transportation, or transporting any dangerous goods without complying with all applicable safety requirements.

At trial, the Provincial Court judge rejected Terroco's due diligence defence, finding that Terroco had an insufficient training and supervision program. He held that while human error was inevitable, to establish the defence of due diligence Terroco had to show that it had 
systems in place to minimize the possibility of error and to deal with its consequences. Terroco could not merely point at an existing training and supervision program as being all it could reasonably do to avoid error. Finding Terroco guilty under both the $E P E A$ and the $D G T H A$, the trial judge fined Terroco $\$ 50,000$ for the EPEA offence and $\$ 5,000$ for the $D G T H A$ offence. Terroco appealed the convictions and the Crown appealed the sentences to the Alberta Court of Queen's Bench, which upheld the convictions and held that the fines imposed were demonstrably unfit, increasing them to $\$ 150,000$ and $\$ 15,000$ respectively.

Terroco further appealed the sentencing decision to the Alberta Court of Appeal, and leave was granted on the question of what principles should be applied when sentencing pursuant to environmental protection legislation.

\section{DECISION}

With respect to determining the appropriate standard of review to apply in sentencing appeals, Ritter J.A., writing for a unanimous Court, confirmed the general rule of deference that "absent an error in principle, a failure to consider a relevant factor, or overemphasis of a relevant factor, a court of appeal should only intervene to vary a sentence ... if the sentence is demonstrably unfit ... in the sense that it is clearly excessive or inadequate by falling outside the acceptable range of orders for the crime and the offender."'28

In considering sentencing principles to be applied, Ritter J.A. identified the following five factors to be considered: (1) culpability; (2) prior records and past involvement with the authorities; (3) acceptance of responsibility; (4) damage/harm; and (5) deterrence. While suggesting that other principles may be relevant in other cases, Ritter J.A. found that only these factors were applicable in the matter before the Court.

\section{a. Culpability}

According to Ritter J.A., "[c]ulpability should be a dominant factor in sentencing for environmental offences," ${ }^{29}$ noting that maximum sentences for intentional acts under the $E P E A$ are twice that for unintentional acts. Under this theory, the more diligent the offender, the lower the range of appropriate sentences; conversely, the less diligent the offender, the higher the range of appropriate sentences. In other words, offences that involve recklessness deserve more severe penalties than those that are near due diligence misses.

In determining the degree of culpability, the Court held that an accused's failure to take "simple and inexpensive steps to avoid the unwanted consequence" ${ }^{\text {"130 }}$ will be an aggravating factor, and if the event is one that was reasonably foreseeable, that fact will also impact on the sentence.

A common thread running through Ritter J.A.'s decision is that in matters of sentencing it is important to fully understand the gravamen of the offence. To consider the degree of 
culpability, sentencing judges are instnucted to "rigorously assess the facts of the predicate offence to see where the offender's conduct lies on the continuum between virtual due diligence and virtual intent." ${ }^{\text {131 }}$ This correlation between due diligence and sentencing reinforces the need for companies to ensure that adequate environmental training and safety programs are implemented and maintained, something that the Court found was lacking in this case.

After reviewing the lacts, Ritter J.A. found that this was not a case involving a due diligence "near miss." The Court held that numerous foresecable factors existed that contributed to Terroco/s culpability, including a failure to ensure that workers were sufficiently trained and had sufficient support from head office. The evidence showed that Terroco often tried to operate in a cost-effective way without properly considering that inexperienced personnel placed the environment and the public at risk. However, Ritter J.A. stopped before finding that Terroco's conduct involved a conscious decision to accept risks in the interests of maximizing profits.

\section{b. Prior Record and Past Involvement with the Authoritics}

The Court stated that the existence of a prior record of warnings or convictions can be an aggravating factor if the offender is shown to be more concerned with profit than compliance. Justice Ritter found that this was not the case here, noting that Terroco had no prior record showing any convictions, charges laid, or warnings under the EPEA. As the incidents consisted of two events over a short period of time, the logical inference is that the offences were related and isolated events, although the employee's inexperience and lack of proper training suggested that the offences resulted from more than just bad luck.

\section{c. Acceptance of Responsibility/Remorse}

While an early guilty plea to an environmental offence is a mitigating factor, Ritter J.A. was clear to note that pleading not guilty (as Terroco had done) and proceeding to trial is not an aggravating factor since the right to a trial is fundamental. However, the Court suggested that an accused that proceeds to trial must be scrutinized to determine if it in fact sees no error in its actions. If that attitude on the part of the accused is discernable from the evidence, the accused will be presumed to be more prone to reoflend than one who recognizes its guilt and takes responsibility: The presence of the former over the latter would obviously be an aggravating factor in sentencing. ${ }^{132}$

Additional mitigating factors relating to the principle of acceptance of responsibility include where the offender failed to take reasonable steps to address the release immediately, whether the accused remediated the contamination (and whether such remediation was done as part of a genuine plan to ensure that the damage was minimal and whether it was carried out in cooperation with the authorities), and finally whether the offender made a voluntary payment of damages to persons harmed by the offence. On these points, Ritter J.A. found 
that Terroco cooperated with the authorities and cleaned up the well site at its own expense, and further that it voluntarily paid all costs associated with both releases.

\section{d. Damage/Harm}

With respect to harm suffered by others, the existence, potential, duration, and degree of harm are factors to be fully considered in sentencing for environmental offences. According to Ritter J.A., "[d]ifficulties in attribution and the gradual effect of cumulative actions often make the determination of actual harm an impossible exercise." ${ }^{133}$ As such, while actual harm is an aggravating factor, especially when it was readily foreseeable, ${ }^{134}$ the absence of harm is not a mitigating factor.

The potential for harm (regardless of whether such harm actually occurs) is also a relevant consideration, with proper considerations including the probability of the harm, the nature of the product, the likely magnitude of damage if the risk materializes, and the sensitivity of the site, including its proximity to population and fragile environments. ${ }^{135}$ As the Court noted, "[a]n offender lucky enough to avoid actual harm should not benefit from the intervention of luck."136

Justice Ritter found that the trial judge's failure to consider thoroughly the harm suffered by the worker injured by the gas release constituted a reviewable error for which no deference was owed. While no other serious harm arose, the potential for harm was high, as chlorine gas is highly toxic and spreads easily. In contrast, the spill at the well site produced a less serious risk as it was more readily contained. Using this analysis, the type of harm that occurred, and the existence of potential harm distinguished the EPEA offence from the DGTHA offence.

\section{e. Deterrence}

According to Ritter J.A.:

A key component of sentences imposed for breaches of environmental protection statutes should be specific and general deterrence. Section 2(i) of the EPEA states in clear and unequivocal terms that polluters have a responsibility to pay for their actions. The general theme of this purpose provision is to ensure that damage to the environment does not occur. ${ }^{137}$

Moreover, he noted that the enforcement of a statute such as the EPEA calls for a significant element of specific deterrence, and the maximum fines available to sentencing judges are high. This should be interpreted as a message from the legislature that it does not view low or nominal fines as meeting the goals of the EPEA. As for the DGHTA, while its

13. R. v. Goodstoncy (1999), 232 A.R. 243 (C.A.); R. v. DeSousa, [1992] 2 S.C.R. 944.

13. R. v. Chem-Security (Alberta) Ltd. (1998), 233 A.R. 289 (Prov. Ct.) at paras. 12-14.

136 Supra note 125 at parn. 48.

'3" Ibid. at para. 53. 
maximum fines are not as high, they nevertheless constitute a similar message: the release of dangerous goods during transport calls for a significant level of specific deterrence. ${ }^{13 x}$

According to the Court, whenever a corporate offender is being sentenced the sentencing court should be made aware of the offender's general ability to pay: "Individual deterrence is achieved at a much lesser cost when a small corporation of limited means is to be sentenced than when the corporation is large enough that maximum sentences have limited significance." 139 For this reason, the starting amount when sentencing a corporate offender must be such that the fine imposed appears to be more than a licensing fee for illegal activity or the cost of doing business.

Finally, sentencing judges should consider the size and profitability of the transaction that resulted in the breach and whether it was part of an ongoing series of breaches. Specific deterrence may be achieved in issuing a lesser fine to address an isolated breach by a person of limited means.

Having reviewed the foregoing factors in the circumstances of the facts before it, the Court concluded that Terroco's conduct involved a significant degree of culpability and that the deterrent factor in sentencing for these offences should therefore be quite high. In addition, general deterrence was also engaged because others must be aware that what may appear to be cost effective but risky behaviour will result in a stiff penalty if a release occurs.

Based on the foregoing, the Court concluded that the summary conviction appeal judge's $E P E A$ sentence was appropriate as the trial judge underemphasized the actual bodily injury that resulted. However, because of the distinguishing factors that placed the $D G T H A$ offence in a less serious category, the Court found that the original DGTHA sentence imposed by the trial judge was not demonstrably unfit. As such, the Court of Appeal affirmed the $\$ 150,000$ fine levied by the Court of Queen's Bench on the initial appeal of the EPEA charge, but restored the sentence of the trial judge on the DGTHA charge.

\section{COMMENTARY}

Finally, Ritter J.A. stated that in his view it is impossible to establish sentencing guidelines for the EPEA or the DGTHA:

Offences under thest statules are similar to manslaughter in that they may be committed in practically infinite variety. Manslaughter ranges from near accident to near murder. These offences range from incidents where due diligence is a near miss to ones where the Crown nearly establishes intentional conduct. At the same time, like offences for like olfenders should attract similar sentences. The range of sentence for similar offences by similar offenders should not be so large as to be disparate. ${ }^{140}$ 
As a result of this decision, companies that are charged with offences under environmental statutes can now foresee, with reasonable certainty, the factors that the courts will look to in determining an appropriate sentence. While the Court's five principles are not exhaustive, they will very likely form the basis of future environmental sentencings in Alberta, and perhaps in other provinces as well. While the offences in this case were limited to offences under the EPEA and the DGTHA, we expect that Ritter J.A.'s thorough analysis in Terroco will be very persuasive in sentencing hearings related to offences under other environmental statutes.

\section{B. PEARSON V. INCO LTD. ${ }^{\mid+1}$}

\section{BACKGROUND}

Pearson sought to have an action certified as a class proceeding under Ontario's Class Procecdings Act, $1992^{142}$ on behalf of former and present property owners in Port Colborne, Ontario, and to be appointed as the class representative. The action was brought by Pearson against Inco Ltd. (Inco) for damages in connection with nickel contamination.

\section{FACTS}

For close to 70 years, Inco operated a nickel refinery in Port Colborne, during which time it emitted significant quantities of nickel oxide into the environment, thereby allegedly contaminating the Port Colborne area. Although emissions had long since ceased, in September 2000 Ontario's Ministry of the Environment (MOE) released a report disclosing that Inco had discharged contaminants into the environment that posed a risk to the environment and to human health. Pearson initially brought a claim for a variely of damages, including damages for alleged adverse health effects. His claim also argued that the disclosure of the high level of nickel contamination and widespread testing thereafter by the MOE had a serious impact upon property values in the area. He sought to have his action certified as a class proceeding on behalf of the former and present property owners of much of Port Colborne.

Two lower courts had denied Pearson's application for class certification under the $C P A$ on a number of grounds, including failure to show an identifiable class and failure to establish that a class proceeding was the preferable procedure to address the claims. On appeal to the Ontario Court of Appeal, Pearson restricted his claim to damages for the devaluation of real property values arising from soil contamination. Inco had accepted responsibility for the nickel emissions, but it disputed the claim that the emissions had negatively impacted property values in the area. The Ontario Court of Appeal was asked to consider whether a class proceeding was the more suitable vehicle by which the claims could be advanced. 


\section{DECISION}

The judgment of the Ontario Court of Appeal was delivered by Rosenberg J.A., who noted at the outset that the Supreme Court of Canada had already confirmed in Hollick $v$. Toronto $(\text { City })^{143}$ that, in a proper case, an environmental claim could be pursued through a class proceeding. Justice Rosenberg then noted that although deference was owed to the decision of both the motion judge and the Divisional Court, there were two significant developments since then: (1) in December 2004 the Ontario Court of Appeal suggested that a more liberal approach should be taken to certification of class proceedings under the $C P A ; ;^{144}$ and (2) Pearson had restricted the claim solely to damages for the devaluation of real property values arising from soil contamination.

The Court then reviewed the applicable law in Ontario, noting that for an action to be certified as a class proceeding under the CPA, a court must find that all of the following criteria are met. First, a cause of action must be disclosed. Second, there must be an identifiable class of persons. Third, the claims of all class members must raise common issues. Fourth, a class proceeding must be the preferable procedure for resolution of the common issues. Fifth, there must be a representative plaintiff. Based on these criteria, Rosenberg J.A. proceeded to determine whether a class proceeding was available in the matter before him.

\section{a. Cause of Action}

The Court noted that Pearson had framed his claim in nuisance, negligence, trespass, and strict liability in accordance with the doctrine in Rylands $v$. Fletcher. ${ }^{145}$ Inco argued that in framing the causes of action in this way, Pearson was attempting to complicate the basis of liability so that the action would appear "ripe" for certification as a class proceeding. In Inco's submission, if nickel escaped from its facility then it is liable, and the only issue then would be damages, which would require individual assessments. Justice Rosenberg rejected this argument, noting that while it would be inappropriate for a plaintiff to artificially inflate his or her claims, Pearson was entitled to plead bases for negligence in the alternative. ${ }^{146}$ Certification would only be denied if the common issues among the individual claims were "relatively unimportant," which he noted was not the case in the matter before him.

\section{b. Identifiable Class}

Both the motion judge and the Divisional Court had held that Pearson's proposed class (consisting of those who owned property within a specific area of Port Colborne when the 2000 MOE report was released) was arbitrary. However, Pearson reconstructed this claim for the Court of Appeal, such that it no longer depended on actual levels of nickel concentrations, but whether local property values had been impacted by the MOE's September 2000 report. As such, the basis for a finding of geographical arbitrariness

\footnotetext{
143 2001 SCC 68, [2001] 3 S.C.R. 158 [/lollick].

14 Cloud v. Canada (A.G.) (2004), 73 O.R. (3d) 401 (C.A.) [Cloud].

Its (1868), L.R. 3 H.L. 330.

$146 \quad$ Supra note 141 at para. 49.
} 
disappeared. In light of the Supreme Court of Canada's decision in Hollick, the Court found that it was open for Pearson to define the class by using geographical boundaries, notwithstanding that there will always be an inherent element of arbitrariness in doing so. ${ }^{147}$

Pearson met the identifiable class requirement by defining the class using objective criteria, showing a rational relationship between the class and the common issues. Quoting McLachlin C.J.C. in Hollick, Rosenberg J.A. noted that this requirement merely requires "some showing" that the class is not "unnecessarily broad." 188 He held that there was a logical connection between the claim and the definition of the class, since Pearson sought to certify a class of owners whose property values were allegedly directly impacted by the 2000 disclosures.

\section{c. Common Issues}

On this requirement, the Court quoted from the Ontario Court of Appeal decision in Cloud, wherein Goudge J.A. stated that "the fact that beyond the common issues there are numerous issues that require individual resolution does not undermine the commonality conclusion [but rather] is to be considered in the assessment of whether a class action would be the preferable procedure."149 Accordingly, Rosenberg J.A. found that, despite the fact that the claim before him was much narrower than the claim before the lower courts, Pearson now met the common issue requirement, a fact that Inco did not dispute.

\section{d. Preferable Procedure}

Justice Rosenberg noted that Cloud set out four principles that apply in determining whether a class action would be the preferable procedure, stating as follows:

1. The preferability requirement has two coneepts ut its core: litst, whether the class action would be a fair, efficient and manageable method of advaneing the claim; second, whether the class action would be preferable to other reasonably available means of resolving the claims of class members.

2. The analysis must keep in mind the three principle advantages of class actions: judicial economy, access to justice, and behaviour modification.

3. This determination requires an examination of the common issues in their context, taking into account the importance of the common issues in relation to the claim as a whole.

4. The preferability requirement can be met even where there are substantial individual issues; the common issues need not predominate over the individual issues. ${ }^{150}$

Justice Rosenberg then proceeded to analyze the preferable procedure issue with reference to the three commonly accepted goals of class proceedings to see if they were achieved in 
the matter under consideration: judicial economy, promotion of access to justice, and helping cause behaviour modification.

Respecting judicial economy, the Court noted that the claim as originally framed would not have had the advantage of judicial economy: "The individual claims of injury to health and related claims would dwarf the resolution of the common issues." 151 Nevertheless, the amended claim concerned the single issue of the negative impact on property values. If Pearson was able to demonstrate the effect of public knowledge of contamination on the property values, the only individual issue remaining would be for each class member to show the amount of the effect on his or her property. According to Rosenberg J.A., this individual assessment aspect is not unusual in class proceedings. ${ }^{152}$

In determining whether the claim would promote access to justice, Rosenberg J.A. stated that Pearson's limiting of the claim to the impact on property value strengthened Inco's argument on this point in some respects. However, the Court held that although Inco had undertaken a Community-Based Risk Assessment (CBRA) under which Inco would remediate certain properties on a "no questions asked" basis, the CBRA did not address monetary claims for reduced property values and, therefore, did not fully provide access to justice. The Court noted:

Remediation [under the CBRA] is limited to qualifying individual properties with significant contamination.

It is open to the class members to argue that it does not address the injury already caused. Inco may be able to show that land values may rebound after remediation, but that is an issue for the trial. ${ }^{153}$

The Court also considered the possibility that many of the people whose property values were most seriously impacted could also be the most vulnerable and least able to prosecute their individual claims. Therefore, allowing a class proceeding suit to proceed would, in this respect, likely assist in mitigating the difficulties that could be faced by certain class members if they were forced to advance their claims as test cases or joinder actions against Inco. ${ }^{154}$

Finally, in determining whether the claim would achieve the goal of behaviour modification, the motion judge held that certifying Pearson's claim as a class action would not have achieved the goal of behaviour modification since the MOE was already involved and Inco had already established the CBRA. The Court held, however, that the goal of behaviour modification/should be to "inhibit misconduct by those who might ignore their obligations to the public,"1ss and that, in this respect, the motion judge took too narrow a view of this goal. The Court also found that it was an error in principle for the motion judge to take into account the possibility that Inco might become less cooperative if the action were certified, thus delaying the implementation of the CBRA. Justice Rosenberg stated that "[he does] not agree with the proposition that property owners must abandon their legal rights and

1si Pearson, ibid. at para. 70.

152 $\quad$ bid. al para. 77

153 lid. at para. 80.

15.4 lbid. at para. 84

15s Ibid. at para. 87, quoting Abdool v. Anaheim Management Lid. (1995), 21 O.R. (3d) 453 at 472 (Div. Ct.). 
their right to be made whole in order to buy the co-operation of a defendant they say has caused widespread harm to the community."156

\section{e. Representative Plaintiff}

The Court found that the motion judge had erred when he determined that Pearson had failed the three requirements for acting as a representative plaintiff, namely fair and adequate representation, a workable litigation plan, and no conflict of interest on the common issues.

Respecting the first requirement, fair and adequate representation, the Court quoted from McLachlin C.J.C. in Western Canadian Shopping Centres Inc. v. Dutlon, ${ }^{157}$ explaining that the concept of adequate representation involves

the motivation of the representative, the competence of the representative's counsel, and the capacity of the representative to hear any costs that may be incurred by the representative in particular (as opposed to by counsel or by the class members generally). The proposed representative need not be "typical" of the class, nor the "best" possible representative. The court should be satisfied, however, that the proposed representative will vigorously and capably prosecute the interests of the class. ${ }^{158}$

The Court found that the motion judge erred in holding that in the absence of a commitment from the Class Proceedings Committee to promote funding, it was incumbent on Pearson to have "concrete and specific alternative funding arrangements in place and to provide the specifics of those arrangements in the certification material." 159 Noting that there is nothing in the $C P A$ that imposes such a rigorous requirement, Rosenberg J.A. stated that the capacity of the representative plaintiff to fund the litigation is merely one factor in determining whether it can adequately represent the class.

With respect to the presence of a workable litigation plan, the motion judge had previously held that Pearson's plan was insufficient in that it was too generalized. The Court held that the motion judge had taken an unreasonably rigid view of this requirement by requiring that all the details for the litigation be "within the four comers of the plan itself." 160 Following the approach taken in Cloud, Rosenberg J.A. noted that it was sufficient if the elements of the litigation plan could be compiled from the plan itself and supporting affidavits.

Finally, the Court held that the motion judge had erred in finding that Pearson had a conflict of interest. The motion judge had been concerned that Pearson might have a conflict with other members of the proposed class. As a resident of the area potentially most affected, Pearson likely had an interest in pursuing the claims "in a much more aggressive fashion" than other residents less affected by the contamination. Justice Rosenberg rejected this logic, stating that the Court need only be satisfied that the representative plaintiff "will vigorously and capably prosecute"161 the claim. The Court held that motion judge's finding that

\footnotetext{
ist Pcarsom, ibid, at para. 89.

Is) $2001 \mathrm{SCC} 46,[2001] 2$ S.C.R. 534 [Dulron].

Is* Supra note 141 at para. 93, quoting Dutron, ibid. at para. 41.

159) Pearson, ibid. at para. 94.

(4) Shid. at para. 97.

161 Jbid. at para. 93.
} 
Pearson's keen interest in pursuing the litigation would lead to a conflict of interest was mere speculation.

Based on the foregoing analysis, the Court found that Pearson met the representative plaintiff requirements of the $C P A$ and allowed the appeal.

\section{COMMENIARY}

The decision of the Ontario Court of Appeal is the first common law action in Canada to be certified based on long-term environmental contamination and signifies a more liberal approach to class certifications for environmental claims in Ontario. While it may still be difficult to get certification for claims based on the effects of human health, this decision demonstrates that if class litigants properly frame their claims, they will now have a better chance of achieving class action certification.

Inco has applied for leave to appeal this decision to the Supreme Court of Canada. ${ }^{162}$

\section{FREEHOL.d LEASES}

\section{A. FREYBERG V. FLETCHER CHALLENGE OIL \& GAS INC. ${ }^{163}$}

\section{BACKGROUND}

This case is the long-awaited Court of Appeal consideration of the decision handed down by Romaine $\mathrm{J}$. in 2002 . It is an important decision that clarilies interpretative issues surrounding the "unless" type of freehold lease that has been the subject of much litigation in Alberta. The case also helps clarify the test for determining whether an economic and profitable market exists respecting shut-in wells.

\section{FACTS}

The Court of Appeal offered this concise description of the relevant facts and issues:

Lady Ivry Freyberg is a clderly widow who lives in England. In 1979, she inherited a two-lhirds interest in the mineral tille to certain lands situated in Alberta. At the time she acquired these rights, the lands were subject to a natural gas lease (the "Lease"). The lessee was an Alberta based oil and gas company named Voyager Petroleums Lid. ("Voyager").

In 1978, Voyager drilled the 6-3 Well on the leased lands, but despite promising lest results, Voyager shut this well in. The 6-3 Well remained shut in for 21 years until it was finally put on stream by Voyager's successor in 1999. Once in service, the well proved to be extremely productive and Lady Freyberg became convinced the gas could have been produced earlicr. Therefore, she sued the lessee and all the working interest holders claiming that the Lease had terminaled some time alter 1987 due to a lack of production in 
the face of an economic and profitable market. She sought a declaration to that elfeet. The trial judge denied her request and she appeals that decision.

Lady Freyberg submits that the trial judge made the following errors:

1. The trial judge erred in holding the Lease would not automatically terminate during the secondary term;

2. The trial judge erred in holding that there was no economic and profitable market for the 6-3 Well prior to 1999:

3. The trial judge erred in holding that the respondents had made out a strong case of estoppel;

4. The trial judge erred by finding the word "cheque" found in Clause 22 of the Lease included a postdated cheque: and

5. The trial judge erred in her award of costs against Lady Freyberg. ${ }^{104}$

\section{DECISION}

Set out below is the Court of Appeal's decision respecting the first three issues as described above.

a. Did the Trial Judge err in holding the Lease would not

automatically terminate during the secondary term?

The Court of Appeal rejected the trial court's adoption of an approach that would see a different set of equitics apply to the interpretation of an "unless" type freehold lease depending on whether the analysis was with respect to the applicable lease's primary or secondary term. This was based in part on the trial court having implied into the Lease a term that, absent the ability of the lessee to avail itself of the deeming provision in the shut-in wells clause, the lessee was obliged to produce gas in the secondary term. This obligation allowed the lessee to benefit from the default provisions in the lease requiring the lessor to provide notice to the lessee to remedy the default resulting from the failure to produce and, absent such notice, the Lease was not capable of automatic termination.

In rejecting this analysis, the Court of Appeal sided with the established jurisprudence, which provided authority for the propositions that an "unless" type freehold lease is in fact capable of automatic termination in the secondary term, and that the opportunity to remedy a default pursuant to the provisions of a default clause in a lease is not available absent an obligation. The Court stated:

This implied term circumvents case law which states that failure to produce, when economical and profitable to do so, results in termination of the lease: Camedian Superior Oil of California Led. v. Kanstrup, [1965] S.C.R. 92. The result of termination is that provisions like Clause 18, which provide relief from forfeiture, do not become operalive as there is no forfeiture to relieve against: there cannot be default in neglecting to 
do something that one is not obligated to do: East Crest Oil Co. v. Strohschein and Strohschein. [1952] 2 D.L.R. 432 (Alta. C.A.), at $436 .^{165}$

The Court of Appeal went on to provide reasons supporting a strict interpretation of the Lease. It first noted that a number of policy reasons supported this interpretation, namely: (i) the desire of lessors that wells on their lands be produced as soon as possible and within their lifetime; (ii) the exigencies of the marketplace encourage production whenever it is economical and profitable to do so; (iii) the risk of flooding increases while production is delayed; and (iv) delayed production increases the possibility that the gas of an inactive well will be captured by other wells in the same formation. The Court also offered rationale from the lessee's perspective in support of its interpretation, noting that if the facts at bar gave rise to a claim for damages, the lessee could never abandon or forsake a well without risking a claim for damages. It further noted that there may be instances where a lessee may prefer to give up its interest in a lease and should have the opportunity to do so.

The Court went on to cite additional legal principles in support of its interpretation, noting that the Lease contained an entire agreement clause and that such a clause would normally preclude implying a term as had been done at trial. It then cited the principle that the terms of contracts are to be given effect according to their plain and ordinary meaning unless doing so would result in an absurdity. The Court was of the opinion that the term implied at trial was a departure from the plain and ordinary meaning of the Lease, noting that the only case law offered in support of implying the term was from American jurisprudence out of the state of Oklahoma. The Court again offered authority that Canadian jurisprudence espoused a different, clear principle that failure to produce a well in the secondary term of an "unless" lease results in termination of that lease.

The Court also rejected the respondent's argument that the fourth proviso to the habendum clause of the Lease allowed for a continuation of the primary term. It stated:

The fourth proviso simply extends the Lease when a well drilled within the initial term is shut-in due to an intermittent, uneconomical, unprofitable or absent market. This proviso is subject 10 Clause 3 which imposes an additional obligation on a lessee: payment of a sum equivalent to the delay rental on the anniversary datc of the Lease. I agree with the trial judge that once the uneconomical and unprofitable production condition is met and the delay rental is subsequently paid, the lease extends for a further one year period. This interpretation respects the practicalities and economics of production.

When this meaning is tested against commercial realities it withstands scrutiny. 1 have already identified some of the competing factors which relate to the construction of a natural gas lease. Another factor is the unfaimess of an indefinite extension. To give an interpretation that further enhances the rights of a lessec would place the lessor in an unfair position. Furthermore, reliance on the plain and obvious meaning of the words has the advantage of certainty and is to be preferred unless an absurd result would ensue. The termination of a natural gas lease because of a failure to produce when it is economical and profitable to do so is not an absurd result. ${ }^{\text {Ito }}$ 
b. Did the Trial Judge err in holding that there was no economic and profitable market for the 6-3 well prior to 1999 ?

In considering the proper test to determine the presence of an economic and profitable market, the Court held that Romaine J. erred in applying a test that was similar to the business judgment rule, holding that such an approach did not sufficiently consider the objective elements required. The Court then took the opportunity to clarify the proper test:

\begin{abstract}
The test to be applied is whether, based on information available at the timt, a prudent lessee would have foreseen profitability. A prudent lessee is to be defined on an objective standard influenced by (1) the character and nature of the lessee, and (2) the reasonable expectations of the parties. A lessee experienced in the production of leased substances will be held to a higher objective standard than an inexperienced lessee. The reasonable expectations of the parties also forms a component of this objective standard. Evidence that the lessee foresaw profitability at the relevant time is a major component of that reasonable expectation. If the lessee foresaw profitability, unless it can be demonstrated that its foresight was based on error or oversight, then that foresight will be practically conclusive of the issue.
\end{abstract}

In determining whether a prudent lessee would have abjectively foreseen profitability, the view of the operator may be an important factor. However, while an operator's view of profitability may be influential it is nol determinative as it is ultimately the reasonable view of the lessec that is the focus of the enquiry. ${ }^{167}$

As to the burden relating to the economical and profitable market, the Court canvassed the jurisprudence on the onus of proof in civil actions and concluded that "while the onus of proving her case remains with Lady Freyberg, the burden of proof regarding the issue of deemed production under Clause 3 of the Lease rests with the respondents due to (a) their reliance on an exception to the lease's termination, and (b) Voyager's specialized knowledge and awareness of relevant facts not available to Lady Freyberg."

c. Did the Trial Judge err in holding that the respondents had made out a strong case of estoppel?

Due to the lack of treatment of this issue at trial, the Court of Appeal considered afresh whether estoppel by election had been made out. After setting out the test and relevant jurisprudence, the Court concluded that Lady Freyberg was not possessed with knowledge of all relevant factors, knowledge that is required to successfully argue estoppel by election. Interestingly, the Court also cited Canadian Stuperior Oil Lid. v. Paddon-Hughes Development Co. Ltd. ${ }^{169}$ and echoed the doubt expressed in that case that estoppel could ever operate to save a lease having terminated. It may be that, by virtue of consideration of this issue by the Court of Appeal in this case, Canadian Superior Oil no longer stands for such a proposition.

Justice $O^{\prime} L$ Leary offered a dissenting judgment that considered only whether the trial judge committed a reviewable error in finding that there was not an economical or profitable 
market. Having concluded that Romaine J. had reached her conclusions based upon a careful consideration of the evidence, $O^{\prime} L$ eary J.A. concluded there was no basis for interfering with the assessment of the evidence.

\section{COMMENTARY}

As ably noted in a prior version of this article, Romaine J.'s decision in the Court of Queen's Bench, if affirmed on appeal, would "herald a tidewater change in the interpretation of the 'unless' type freehold lease." ${ }^{170}$ However, the tidewater change did not come, as the Court of Appeal disagreed with Romaine J.'s analysis and findings. The decision of the Court of Appeal in Freyburg confirms and strengthens the historical treatment by Alberta courts that while a lessee is not obligated to produce a well, if it does not do so it will have the burden of proving that the provisions of the habendum clause and the shut-in wells clause of the lease apply in order to deem production. Such a lessee will not be in default under an "unless" type freehold lease and, accordingly, the lease may terminate by its own terms, without notice and with no option for the lessee to prevent such termination.

Applications for leave to appeal were dismissed by the Supreme Court of Canada on 10 November 2005. ${ }^{171}$

\section{B. KENSINGTON ENERGY LTD. V. B\&G ENERGY LTD. ${ }^{172}$}

\section{BACKGROUND}

This recent decision out of the Alberta Court of Queen's Bench further develops the interpretation of the third proviso clause in a typical freehold lease and clarifies its relationship with the shut-in wells clause.

\section{FACTS}

Five freehold petroleum and natural gas leases (the Original Leases) comprising a section of land (the Lands) were past their primary term (the Original Leases were taken out in 1981 and 1988), and had been continued by actual production of natural gas in the upper Mannville zone from a well located on the Lands (the Well). In January 2001, the Well was shut in and shut-in royalty payments were made thereafter by NCE Petrofund Corp. (NCE). NCE had previously acquired the Original Leases as part of a larger package from Westland Resources Inc., the original lessee under them. Sometime after January 2001, NCE removed the wellhead equipment from the Well, but the Well was never abandoned according to the regulations.

In the Fall of 2002, B\&G Energy Ltd. (B\&G) became interested in the Lands as a result of its review of publicly available well information. During its review, B\&G identified 
potential in up-hole zones in the Well, and determined that the Original Leases had most likely expired due to the cessation in production. Shortly thereafter, B\&G instructed a land agent to take out options for petroleum and natural gas leases for the Lands. By February 2003. B\&G had obtained options on the entire section of the Lands and had filed caveats giving notice of these options. At the beginning of March 2003, B\&G contacted NCE to advise of its position on the Lands.

On 16 April 2003 and again on 23 April 2003, the land agent on behalf of B\&G sent letters to NCE demanding that NCE discharge its caveats with regard to the Original Leases. On 30 April 2003, Kensington Energy Ltd. (Kensington) acquired the Original Leases from NCE and the non-producing Well along with other assets for approximately $\$ 10,000$. NCE advised Kensington of B\&G's claims to the Lands prior to closing. Despite this information, Kensington completed its acquisition of the Lands and continued to pay the shut-in royalty payments for the Original Leases. In July 2003, B\&G served Kensington with Notices to Take Proceedings on the caveats for the Original Leases, which Kensington commenced on 11 August 2003. Sometime that same month, Kensington commenced re-completion operations on the Well by abandoning the upper Mannville zone and re-completing the same shallower zone that B\&G had identified. Production began in September 2003, with no production having occurred for over two and a half years prior to that point, and no drilling or working operations having commenced within 90 days of the cessation of production. B\&G exercised its options on 8 September 2003 and filed its Statement of Defence and Counterclaim on 12 September 2003.

\section{DECISION}

Kensington's primary argument was that payment by the lessee to the lessor pursuant to the shut-in wells clause of the Original Leases was, in and of itself, enough to deem production and preserve the Old Leases, regardless of the reasons for production from the Well having ceased. The applicable shut-in wells clause is the same in each of the Original Leases and reads as follows:

Subject to the provisions hereinbefore set forth, if all wells on the said lands are shul-in, suspended or otherwise not produced during any year ending on an anniversary date, the Lessee shall pay to the Lessor at the expiration of each such year, a sum equal to the delay rental hereinbefore set forth and each such well shall be decened to be a producing well hereunder, provided that this clause shall not impose an obligation upon the Lessee to make the payment of a sum equal to the delay rental unless all wells on the said lands are shut-in, suspended or otherwise not produced for a period of ninety (90) consecutive days in any such year. $^{173}$

Alternatively, Kensington argued that if payment of the shut-in royalties on its own was not enough to preserve the Original Leases, the decision by the lessee to cease production of natural gas from the Well in January 2001 was in accordance with good oilfield practice as contemplated by the third proviso of the Original Leases. The applicable third proviso clause is the same in each of the Leases and reads as follows: 
AND FURTHER ALWAYS PROVIDED that if at the end of the said term the leased substances are not being produced from the said lands or lands pooled therewith and the Lessee is then engaged in drilling or working operations thereon, or if at any time after the expiration of the said term production of the leased substances has ceased and the Lessee shall have commenced further drilling or working operations within ninety (90) days after the cessation of said production, then this Lease shall remain in force so long as any drilling or working operations are prosecuted with no cessation of more than ninety $(90)$ consecutive days. and, if such drilling or working operations result in the production of the leased substances or any of them. so long thereafter as the leased substances or any of them ure produced from the said lands, provided further that notwithstanding anything hereinbefore contained or implied to the contrary, if drilling or working operations are interrupled or suspended as the result of any cause whatsecver beyond the Lessee's reasonable control or if any well on the said lands or on any spacing unit of which the said lands or any portion thereof form a part, is shut in, suspended or otherwise not produced for any cause whatsoever which is in accordance with good oil field practice, the time of such intemuption or suspension or non-production shall not be counted against the Lessec. ${ }^{174}$

B\&G countered with the argument that the application of the shut-in wells clause is expressly subject to the liabendum clause and, in particular, the third proviso found at the end of that clause. More specifically, B\&G argued that the words "[s]ubject to the provisions hereinbefore set forth" found at the beginning of the shut-in wells clause have a meaningful application in this context and cannot be ignored. In B\&G's submission, the payment of an amount equal to the delay rental pursuant to the above shut-in wells clause is not sufficient, on its own, to continue the Original Leases. $B \& G$ argued that a lessee in those circumstances is required to prove that the Well was "shut-in, suspended or otherwise not produced for any cause whatsoever which is in accordance with good oilfield practice" as set out in the third proviso.

Justice LoVecchio of the Court of Queen's Bench rejected both of Kensington's arguments and held in favour of B\&G. He agreed with B\&G that the shut-in wells clause must be read as being subject to the third proviso and not as an independent and distinct means of prolonging the Original Leases. Furthermore, LoVecchio J. concluded that, based on the information contained in the various trial exhibits (Kensington chose not to call any witnesses from NCE), NCE had ceased producing the Well because it had essentially become a dry hole, which conclusion was further evidenced by the fact that NCE had removed its surface equipment from the wellsite. Accordingly, in the Court's view, NCE's decision to suspend production had nothing to do with "any cause whatsoever which is in accordance with good oilfield practice" as suggested by Kensington. The Court observed that Kensington took steps to permanently abandon the original production zone once it obtained possession of the Well. As for whether the cessation of production from the Well was in accordance with good oilfield practice, the Court stated that, in its view, "it was not intended by the parties to the Leases that this scenario was to be available in these circumstances."175 Considering the question of what constitutes "good oilfield practice," LoVecchio J. held that a cause which is in accordance with good oilfield practice is not something that the Lessee may unilaterally dictate or control, and that an independent standard must govern. He suggested that the cause would have to be something temporary in nature and that there 
would have to be some expectation that production would recommence at some time in the fulture.

\section{COMMENTARY}

This decision is consistent with the Alberta Court of Appeal decision in Freyberg and, like Freyberg, it was determined on its particular facts, including the language contained in the Original Leases. The Court concluded that given the language of the Original Leases, payment of the shut-in royalties on its own was not enough to extend the Original Leases but rather the third proviso had to be complied with as well. Further, the Court concluded that the Well as it was left by NCE was essentially a dry hole and that the cessation of production was not temporary in nature and was not done for reasons consistent with good oilfield practices. Kensington has appealed this decision to the Alberta Court of Appeal.

\section{Guarantees}

\section{A. KKBL NO. 297 VENTURES LTD. V. IKON OFFICE SOLUTIONS INC. ${ }^{176}$}

\section{BACKGROUND}

Before the Supreme Court of Canada's ruling in Crystalline, ${ }^{177}$ the leading case regarding the survival of lease obligations post-bankruptcy was Cummer-Yonge ${ }^{178}$ which distinguished between guarantors and assignors of a repudiated lease. While assignors of a lease were considered to have primary obligations that survived a disclaimer of the lease, a guarantor's obligations disappeared when the lease ended. The law in this area changed substantially with the recent decision in Crystalline, which dealt with a repudiated lease for which the landlord attempted to recover unpaid rent from a tenant that had never been released from its original obligations. That decision was rendered after the trial decision of Blair J. in $K K B L$ No. 297.

\section{FACTS}

This decision arose out of an appeal by KKBL No. 297 Ventures Ltd. (KKBL), an owner of a commercial building, from a dismissal of its action for damages for breach of an indemnity agreement against IKON Office Solutions Inc. (IKON), a former tenant. Earlier, IKON had asked to be released from its lease with KKBL and arranged for a new tenant, Gun-for-Hire (Vancouver) Co. (Gun) to occupy the premises. KKBL granted Gun a ten-year lease and IKON agreed to enter into an indemnity agreement with KKBL whereby IKON guaranteed Gun's obligations for approximately three years in exchange for being released from its lease with $\mathrm{KKBL}$.

Shortly after these arrangements were concluded, Gun defaulted on its lease payments, vacated the property, and was subsequently adjudged bankrupt. When the Trustee in 
Bankruptcy disclaimed Gun's lease, IKON declined to make further payments, contending that it was only liable to indemnify KKBL pursuant to the indemnity agreement, and that this obligation terminated with the disclaimer of Gun's lease.

KKBL launched proceedings against IKON, seeking to enforce the financial obligations assumed by IKON under the indemnity agreement. KKBL's claims were dismissed at trial, and it appealed to the British Columbia Court of Appeal based upon the intervening decision of the Supreme Court ofiCanada in Crystalline.

\section{DECISION}

Addressing the issue of whether the trustee's repudiation of the lease affected the indemnity agreement entered into by IKON and KKBL, the Court applied Crystalline and held that the indemnity agreement remained in effect. IKON, as guarantor of Gun's obligations under this agreement, was not discharged of its obligations.

The Court held that authorities upon which the trial judge had relied were no longer valid given the Supreme Court's decision in Crystalline, where Major J. held that the distinction that the law had maintained to that point between post-disclaimer assignors and guarantors was artificial. The Court summarized the reasoning of Major J.'s decision, stating that

the scheme of bankruptcy legislation permitted an individual such as a guarantor to prove in the hanknuptcy proceedings as a general ereditor. He was no better and no worse off than other creditors. There was no need to go further under the statutory scheme than to permit the bankrupt to avoid obligations under the lease to his landlord, but the obligations of others to the landlord should remain unimpaired. ${ }^{179}$

Although the facts in this case involved an original tenant and not an assignee of the tenant as was the factual situation in Crystalline, the Court held that the reasoning of Major J. applied to both situations. Thus, given that Crystalline fundamentally changed the applicable law and foundation upon which the decision of the trial judge relied heavily, the Court held that the trial decision could not be sustained and allowed the appeal.

\section{COMMENTARY}

Both this decision and Crystalline should provide significant comfort to landlords by effectively putting to rest concerns about guarantees or indemnities not surviving the bankruptcy of a tenant. At the same time, these cases should serve as a warning to guarantors of a tenant's obligations under a lease, as they will no longer be able to benefit from the bankruptcy of the tenant. 


\section{SuRface Rights}

\section{A. MaRITIMES AND NORTHEAST PIPELINE LTD. PARTNERSHIP V. ELLIOTT ${ }^{180}$}

\section{BACKGROUND}

This case provides insight as to the scope of the rights of a surface owner under the provisions of the National Energy Board $A c t,{ }^{181}$ which provide for compensation for lands taken or used pursuant to the legislation.

\section{FACTS}

Maritimes and Northeast Pipeline Ltd. Partnership (MNP) constructed a pipeline near a parcel of privately owned land. Neither the pipeline itself nor the $25 \mathrm{~m}$ right of way traversed or physically impacted the private lands. Except for a small portion, the lands were situated adjacent to the $30 \mathrm{~m}$ "controlled area" established under the $N E B$ Act. The landowners, Clayton and Linda Elliott (the Elliotts), advanced a claim for the diminution of the capital value of their property due to its proximity to the pipeline, and requested the Minister appoint an arbitration committee pursuant to Part V of the NEB Act. The Minister agreed and appointed a committee. MNP took the position that the arbitration provisions of the NEB Act did not apply to the type of claim put forward by the Elliotts and brought an application for judicial review of the Minister's decision.

\section{DECISION}

Relying on Balisky v. Canada (Minister of Natural Resources), ${ }^{182}$ the Court determined that, with respect to the Minister's decision to appoint an arbitration committee under s. 91 of the NEB Act, the standard of review is correctness.

MNP's primary argument was that the claim did not fall within the scope of the NEB Act because the damages suffered did not flow from the direct activities of the company. MNP submitted that, while the $N E B A C t$ did provide for compensation, such compensation is circumscribed by the provisions of the $A C t$ itself, and that, in and of itself, the existence of a pipeline in the vicinity of the Elliotts' lands was not sufficient to provide a claim for compensation under the NEB Act.

The Court briefly set out the principles relevant to expropriation or injurious affection, noting that where expropriation is authorized by statute, the right to compensation must also be found in the statute and that the losses claimed must be natural and reasonable consequence of the expropriation. The Court further noted the distinction between land that is taken, which connotes a presumption in favour of compensation, and land that is not taken, where no such presumption arises. The issue at bar was whether the NEB Act provided for 
compensation for injurious affection and, if so, whether it distinguished between scenarios involving land that has been taken and those where it has not.

The Court agreed with MNP, holding that the $N E B$ Act provides for compensation in two scenarios: (1) compensation for the taking or use of land within the right of way granted in connection with the pipeline; and (2) compensation for damages done by the company in the exercise of its powers as delineated in s. 73 of the $N E B$ ACt. It stated:

Section 84 provides that negotiation and arbitration procedures apply to damage caused by the pipeline or anything carried by it, but do not apply to claims arising out of the activities of the company except where those activities are directly related to the acquisition of lands, or the construction, inspection, maintenance or repair of the pipeline. ${ }^{183}$

The Elliotts contended that the reasoning espoused in Balisky applied to their claim by analogy, wherein it was held, inter alia, "that the claims arising with respect to landowners [in] ... the section 112 controlled area ... arise by virtue of the presence or existence of the pipeline."184 However, the Court distinguished Balisky on its facts, noting specifically that the lands that were the subject of Balisky were within and subject to the restrictions and limitations applicable to the controlled area. In this matter, however, the lands were adjacent to the controlled area, and were therefore not subject to the compensation scheme in the $N E B$ Act:

Lands in the controlled anca may sustain damage, due to the existence of the pipeline, because of the legislated limitations regarding those lands. No such limitations apply to lands located beyond the controlled area. Neither the legislation nor the case law supports a claim for damages arising from the existence of a pipeline with respect to lanids adjacent to the controlled area. Thus, the right to compensation in this regard ends with the controlled area. If there is no right to compensalion, it follows that there is no right to arbitration. $^{185}$

\section{COMMENTARY}

The decision in Balisky seems to have clarified that compensation, via the arbitration provisions of the $N E B A c t$, is available in respect of lands lying beyond the right of way but within the controlled area. This case makes clear that the right to compensation respecting lands within the controlled area is derived out of the statutory limits applicable to the lands and that the right to compensation ends with the controlled area. However, what is not readily apparent is whether a claim similar to the one advanced by the landowners, being for the diminution of the capital value of property due to proximity to a pipeline, would be successful if such lands were located outside the right of way but actually within the controlled area. 


\section{B. IMPERIAL OIL RESOURCES LTD. V. 826167 ALBERTA INC. ${ }^{186}$}

\section{BACKGROUND}

This decision of the Alberta Court of Queen's Bench, on appeal from the Surface Rights Board (SRB), provides guidance as to what factors are appropriate for consideration by the SRB when determining surface lease rates, particularly where the rates sought are in excess of those in effect for similarly situated lands.

\section{FACTS}

At the hearing before the SRB, the surface lessor, 826167 Alberta Inc. (826167 or the defendant), argued that the nature of the ranching operations that it conducted on the subject lands was so unique compared to other ranching operations in the area that the number and nature of leases adversely affected its ability to secure the lands and the effectiveness and safety of its ranching operations, and that the value of its ranch was diminished as a result. Additionally, the defendant tabled before the SRB examples of higher rates paid by other surface lessees on the subject lands that were consistent with the rates it sought from the plaintiff, Imperial Oil Resources Ltd. (Imperial). The SRB accepted the defendant's arguments and varied the aggregate amount payable by the plaintiff under its surface leases with Imperial from $\$ 95,191.50$ to $\$ 179,750$ per year. Imperial appealed the SRB's decision.

\section{DECISION}

The Court began by noting that the Surface Rights $A \mathrm{Cl}^{187}$ provides that the appeal is by way of a new hearing before the Court, with the SRB's findings to have "substantial evidentiary value since [the SRB] has acquired expertise in these matters."

The Court then observed that the Surface Rights Act provides that the appropriate considerations for the SRB are: (1) the loss of use of the area under the leases; and (2) the adverse effect of the area subject to the surface lease on the balance of the lessor's lands, with emphasis on nuisance, inconvenience, and noise factors. The Court noted that evidence of an established pattern of dealing is also helpful and should serve as a guide, but that any such analysis: (1) should not distract the SRB from applying the "loss of use" and "adverse effect" considerations that should always remain its focus; and (2) presupposes "comparable patterns of dealing" or, in other words, should emphasize comparable leases involving other landowners in the area and not just on leases negotiated by the defendant on the same lands or other lands that it owned. The Court stated:

In Lecuyer Cattle Co. v: Co-operative Energy Development Corporation [1985] 5 W. W.R. 555, McCallum

J. concluded that negotiated settlements are not a proper factor for the Board to consider in determining compensation. The reason for this approach is obvious. Such agrecments then become part of a limited pattern of dealing by way of consent agreements. In these cases those agreements do not break down the 
payments into the two heads of compensation and therefore provide litte guidance to third parties or the Board when relying on such agreements. The danger in relying on such Consent Orders, alone, is that it establishes a limited pattern of dealings which does not accurately reflect the broader recognized value of these leases. In this case the Board, without giving reasons, preferred the limited pattern of dealings suggested by Mr. DeClerq, on his own lands, with a limited number of companies, in relation to a small number of wells, as against clear evidence of an established pattern of dealings encompassing a large number of welts, involving major producers on adjacent similarly positioned lands. ${ }^{189}$

The Court found that the SRB had minimized, or even ignored, the criteria mandated by the Surface Rights Act in favour of the defendant's arguments as to the uniqueness of its ranching operations and the terms of other leases that it had obtained from other lessees. In particular, the Court held that evidence of the terms of other leases involving the defendant on the same lands should be given less weight than leases involving independent parties in the area, given the defendant's inherent conflict of interest. The Court also noted that the uncontroverted evidence before it indicated that the defendant had erected roadblocks at various entrance points to the lands within Imperial's valid surface leases, and that the defendant had used similar negotiating tactics with other surface lessees on land it owns. Further, the Court held that while the defendant argued strenuously that its operations were so unique ${ }^{190}$ that Imperial's wellheads and access roads caused it to suffer more significant losses than other ranchers in the area, the defendant had not discharged the evidentiary onus on it to prove that uniqueness. Accordingly, the Court determined that any weight the SRB had given to the course of dealings put forward by the lessor as comparative examples was to be diminished. This, coupled with expert cvidence led by Imperial as to the actual values that result from a proper consideration of the "loss of use" and "adverse effect" factors, led the Court to overtum the SRB's ruling and reduce its award to the defendant from $\$ 179,750$ to $\$ 120,340$.

\section{COMMENTARY}

As part of its judgment, the Court awarded Imperial an additional $\$ 5500$ for legal costs incurred from obtaining an interim injunction against the defendant who had blocked a number of its entrances to the leased lands. The Court noted that the defendant's principal had a long history of being aggressive in his business dealings, and while this approach had proved very successful for him in his private business dealings, it ultimately contributed to his downfall here.

The defendant was recently granted leave to appeal this decision by the Alberta Court of Appeal. ${ }^{191}$

190 The defendant led evidence that its operations involved rounding up cattle with a number of customized Iractors, and that the presence of the wellheads on the lands presented a danger to its employees as they conducted such operations. 


\section{RIGHTS OF FIRST REFUSAL.}

\section{A. LINEDATA SERVICES S.A. V. KATOTAKIS ${ }^{192}$}

\section{BACKGROUND}

Often the terms of a right of first refusal clause (ROFR) are not entirely clear from its language, or the circumstances that evolve over the course of the triggering and the exercise of the ROFR do not fit neatly within a well-drafted ROFR clause, or both. In either case, the finder of fact in the first instance will inevitably have to rely on factors other than a plain reading of the clause in order to interpret it properly. The following decision highlights two important principles. First, when faced with an ambiguous ROFR clause or with circumstances that do not fit neatly into those contemplated by the clause, a court will interpret the right of first refusal, including the notices and other documents issued pursuant to it, in a manner consistent with commercial reality and common sense. Second, once the finder of fact has made these determinations, an appellate court should not lightly interfere with them.

\section{FACTS}

Stamos Katotakis (Katotakis), William R. Waters (Waters), and BNY Capital Corp. (BNY) owned shares in Financial Models Company (FMC). FMC became publicly traded in 1998, though Katotakis, Waters, and BNY retained 80 percent of the shares. The shares were subject to a shareholders agreement that contained a ROFR and a right of first offer. A transaction among the three parties was formulated that triggered the ROFR and, in accordance with its terms, Waters and BNY delivered notices to Katotakis offering to sell him their shares at a price of $\$ 12.20$ per share.

Since the ROFR did not clearly set forth the terms on which any purchase and sale of shares pursuant to them would occur, Waters and BNY prepared the notices such that they provided that such transactions occur on "terms and conditions ... substantially in accordance with the terms and conditions set forth' in a draft acquisition agreement between FMC and Linedata Services S.A. (Linedata) and in a draft lock-up agreement between Waters, BNY, and Linedata 'to the extent [that the lock-up agreement was] applicable' to Katotakis." ${ }^{103}$ Both the draft acquisition agreement and the draft lock-up agreement contained "superior proposal conditions" that permitted Waters and BNY to sell their shares to a further buyer at a better price, provided that any initial buyer under the ROFR or right of first offer was given notice of any such proposal and the opportunity to match or better it. ${ }^{194}$

Katotakis delivered acceptances to the ROFR notices, expressly accepting all terms and conditions contained in them. In addition, he delivered a takeover bid for the rest of the shares as required by the shareholders agreement and Ontario securities laws. However, Linedata subsequently delivered a further proposal to purchase the shares at $\$ 14.50$. Waters 
and BNY then gave Katotakis notice of Linedata's superior proposal, but Katotakis did not make a further offer. ${ }^{195}$

Katotakis claimed that the superior proposal made by Linedata did not affect or apply to his acceptance of the offer under Waters' and BNY's initial ROFR notices, and that he was entitled to purchase the shares at \$12.20. Waters and BNY argued that they were entitled to sell their shares to Linedata at the higher price.

\section{DECISION}

Justice Ground of the Ontario Superior Court of Justice held that the offers contained in the ROFR notices to Katotakis incorporated the superior proposal conditions contained in the acquisition and lock-up agreements. In his decision, he noted that "at the time the selling notices were delivered and accepted, all parties were aware that FMC was in play ... and they must have been aware that there was the potentiality of a competing bid to the bid being made by [Katotakis]." 196 Accordingly, Ground J. dismissed Katotakis' claim and ruled that the proposed sales to Linedata could proceed.

On appeal, the Ontario Court of Appeal found that the wording of the documents left it open to the lower court to find that the superior proposal provisions were incorporated into the notices, and held that there were no grounds before it that would justify interfering with this finding. ${ }^{197}$ Relying upon the Supreme Court of Canada decision in Consolidated-Bathurst Export Lid. v. Mutual Boiler \& Machinery Insurance Co. ${ }^{198}$ the Court held that " $t$ ]o the extent there is any ambiguity or uncertainty, the selling notices and the terms of the shareholders' agreement should be interpreted in light of the commercial practicalities of the situation confronting the parties and in a manner that will produce a commercially fair and sensible result." 199 In the Court's view, to interpret the offers as Katotakis suggested would be "contrary to commercial reality and good sense." 200 The Court further noted that the shareholders agreement expressly permitted a selling party to include in its notice "any other terms and conditions not contrary to Article 4,"201 and it was not suggested that the superior proposal conditions were contrary to Article 4. On the contrary, the terms of the superior proposal condition achieved a commercially logical balance among the parties: Katotakis maintained the right to have the final opportunity to purchase the shares, but he did not have the right to preclude Waters or BNY from realizing a higher value for their shares.

\section{COMMENTARY}

In its reasons for judgment, the Ontario Court of Appeal pointed out that if it accepted Katotakis' argument, Katotakis would be able to acquire the shares under his original offer

Sup. Ci. J.).

147 Katorakis (C.A.), lbid. ut para. 10.

188 [1980] I S.C.R. 888.

10 Supra note 192 at para. 12.

200

201 
at the lower price and then sell them to Linedata at the higher price, a result that the Court noted was not supported by the agreements and was not consistent with a common sense interpretation of them. The Court also noted that at the outset of the appeal, Katotakis had applied to introduce new evidence of a further offer from a prospective third-party purchaser at a price higher than that offered by Linedata. Although the Court then pointed out that accepting such evidence was not overly relevant to the issues before it, it agreed to do so for the purpose of providing itself with the fullest picture of all of the circumstances as they were playing out among the parties at the relevant times. Ironically, the Court relied on this new evidence to support further its decision on the basis that if Katotakis' application was granted, he would likely be able to sell the shares to this new prospective purchaser and realize an even greater profit on that sale. Logically, the Court felt that such an outcome would be even more contrary to commercial reality and good sense than if Katotakis were entitled to purchase and sell Waters' and BNY's shares to Linedata, which the Court had already determined to be inconsistent with a common sense interpretation of the agreements.

In light of this decision, drafters of rights of first refusal, rights of first offer, and other preemptive purchase rights need to be aware that if the commercial arrangements being provided for in the clause being drafted depart significantly from commercially standard practices and the clause is loosely drafted or missing key provisions, a court will be very reluctant to find that the clause should be construed as achieving a particular result if that result cannot be supported by a common sense interpretation of the clause.

\section{B. APEX CORP. V. CECO DEVELOPMENTS LTD..$^{202}$}

\section{BACKGROUND}

Parties to an agreement containing a ROFR should think long and hard before completing a transaction while refusing to comply with, or simply ignoring, the ROFR. Here, one party went so far as to ask the other party to waive its ROFR. However, when the second party refused to do so, the requesting party nevertheless proceeded with a complex corporate reorganization that involved at least one disposition of the ROFR-encumbered property along with other properties not subject to the ROFR - without first offering it to the ROFR holder. As the transacting party later learned, absent a clear exception within the body of the clause allowing it to ignore the ROFR, a court will likely take a dim view of such behaviour.

\section{FACTS}

Apex Corp. (Apex) entered into a joint venture agreement with Ceco Developments Ltd. (Ceco) to jointly develop a multi-family residential project, each as to a 50 percent interest in the joint venture. Title to the lands on which the project was to be developed (the Lands) was held jointly by Ceco and Apex, with Ceco as the operator of the project. The agreement contained a standard ROFR clause in favour of each party. However, the clause did not contain an express exception for transfers to affiliates, or transfers made pursuant to corporate reorganizations. 
Apex undertook a complex corporate reorganization that resulted in its interests in the joint venture being held by a newly created and separate corporation. However, that corporation bore Apex's name "The Apex Corporation" and held Apex's interest in the joint venture. As part of the reorganization, Apex had changed its name to a numbered company, 39435 I Alberta Ltd. Apex's transfer of its joint venture interest represented only part of several transactions that were completed as part of the reorganization.

Prior to the reorganization, Apex sought a waiver of Ceco's ROFR, which Ceco refused to provide. After the reorganization occurred, Ceco issued an offer under the buy/sell provisions of the joint venture agreement to the entity that it believed to be Apex. A number of changes were made to the offer during the process of negotiating and executing it, including changes by Apex to reflect its new name. These changes raised Ceco's suspicions. It investigated Apex's reorganization transactions and eventually learned that the party named "The Apex Corporation" registered on title to the Lands was not the same corporation that had executed the joint venture agreement. Ceco later informed Apex that it would not be closing the transaction negotiated under the offer because it could not obtain financing. and then brought these proceedings against Apex for breach of its ROFR.

\section{DECISION}

The Court of Queen's Bench found that the ROFR was trigged by the reorganization of Apex. Justice Brooker relied on a number of factors in reaching this decision. First, the ROFR applied to all dispositions to any "third party" and did not contain an exception for dispositions to non-arm's length parties that is commonly included in such clauses. Apex argued that because the "new Apex" possessed the same management, employees, and directors and was controlled by the same shareholder as the "old Apex," it was essentially the "same entity" and therefore was not a "third party" for the purposes of the ROFR clause. Justice Brooker dismissed this argument as being inconsistent with "several decades of company law."203

Apex then argued that the ROFR should not be triggered because the transactions involved non-arm's length parties, even though the terms of the ROFR clause itself, which was quite clear and unambiguous, did not include an exception for dispositions to affiliates. Apex relied on a short line of case law out of the United States where various lower court decisions had held that the word "sale" essentially meant "arms-length sale" for the purposes of the respective rights of first refusal before them. The Court considered an in-depth analysis of this body of U.S. decisions by Professor Robert Flannigan ${ }^{204}$ and agreed with Professor Flannigan that these decisions rely heavily on assumptions and implied exceptions to ROFR provisions that otherwise clearly applied to the facts at bar, and that there is no sound juridical basis to import "a default rule of this nature."20s 
Lastly, the Court rejected Apex's submission that a ROFR applicable to one property is not triggered when that property is only one of numerous properties being sold, i.e., a "package sale." Justice Brooker noted that the ROFR provision before him did not contain an exception for package sale transactions, that the arguments advanced by Apex in this regard were not widely accepted, and that the "fundamental laws of contract interpretation militate against the automatic application of an exception for package sales in all ROFRs."2016 Accordingly, Brooker $J$. held that the ROFR contained in the joint venture agreement between Apex and Ceco had been triggered and that Ceco was entitled to damages for breach of that clause by Apex.

\section{COMMENTARY}

In his paper entitled "The Legal Construction of Rights of First Refusal,"207 Professor Flannigan succinctly sums up the problem faced by $A$ pex and others in similar situations who negotiate rights of first refusal and then try to avoid having to comply with them out of concern that the ROFR holder might actually exercise its right. In his words, "[t]he ex ante solution to this possibility, as it is generally, is to negotiate an express exception. The ex post solution is to obtain a waiver or release from the holder of the right." ${ }^{208}$ In effect, these are the only truly eflective solutions. Parties that are either considering creating such preemptive rights or that are looking to see if they can avoid strictly complying with their obligations under existing rights would be wise to recognize this.

\section{PETRoKaZAKHSTAN INC. V. LUKOLL OVERSEAS KUMKoL B.V. ${ }^{209}$}

\section{BACKGROUND}

A number of Canadian and U.S. oil and gas companies have discovered, through sad experience, that participating in oil and gas joint ventures in the former Soviet Union is not for the faint of heart. Often, it appears that locally-biased arbitration panels have denied these companies natural and procedural justice in joint venture disputes brought before them, including in connection with rights of first refusal and other pre-emptive rights. In this case, somewhat ironically, the opposite is true: the foreign joint venture partner is applying in an Alberta court for, inter alia, the interpretation of a pre-emptive right in an agreement that stipulates arbitration as the exclusive forum for dispute resolution, as well as for relief that, if granted, would give it significant leverage in foreign arbitration proceedings that it has already initiated overseas.

\section{FACTS}

Lukoil Overseas Kumkol B.V. (Lukoil) and PetroKazakhstan (PK), a publicly traded Alberta corporation, each held 50 percent of the shares of Turgai, a Kazakhstan company that held petroleum licences in Kazakhstan. PK had acquired its shares in Turgai by way of

\footnotetext{
soo lbid. at para. 54.

So: Flannigan, supra note 204.

20 lbid. at 26.

sw 2005 ABQB 789, 12 B.L.R. (4th) 128.
} 
assignment from one of its subsidiaries, AO PetroKazakhstan Kumkol Resources (PKKR), which had subscribed for such shares when they were originally issued several years previously. At the time of that subscription, PKKR entered into a shareholders agreement with Turgai and Lukoil. This agreement contained pre-emptive purchase rights restricting the ability of either shareholder to sell its shares of Turgai to a third party without first allowing the other shareholder to acquire them on the same terms (the ROFR). It also contained change of control provisions which triggered the ROFR in the event that a change of control occurred within a shareholder's parent corporation. The shareholders agreement also permitted a shareholder to assign, with no triggering of the ROFR or requirement of consent in favour of the other shareholder, its interest to an affiliate that had sufficient financial and technical ability to perform its obligations thereunder. More than a year following the execution of the shareholders agreement, PKKR assigned all of its shares to its parent corporation, PK. Consistent with the "affiliate transfer" exception, PKKR did not deliver a ROFR notice to Lukoil, and Lukoil did not request such a notice.

Several years later, PK applied to the Alberta Court of Queen's Bench for a final order pursuant to s. 193 of the Alberta Business Corporations Acr' ${ }^{210}$ approving an arrangement to sell all of its issued and outstanding shares to a wholly-owned subsidiary of China National Petroleum Corporation (CNPC). Under the arrangement agreement, CNPC was entitled to withdraw from the transaction if the court did not approve the order by 30 November 2005. PK obtained an opinion from a financial advisor that the arrangement was fair to shareholders and in the best interests of PK (the price offered by CNPC amounted to a premium of US\$1.7 billion to PK's shareholders), and the arrangement was approved by over 99 percent of its voting shareholders.

Lukoil brought an application before the Alberta Court of Queen's Bench claiming that PK's arrangement agreement with CNPC violated the change of control provision and thereby triggered the ROFR provision of the shareholders' agreement. In accordance with stipulations contained in the shareholders' agreement, Lukoil brought arbitration proceedings with respect to its claims against PK. This arbitration was in progress at the time of Lukoil's application. Lukoil thenibrought the within application seeking a dismissal or stay of PK's petition for approval of the arrangement agreement. Lukoil claimed that a final order approving the arrangement would be tantamount to the confiscation by PK's shareholders of Lukoil's pre-emptive rights under the shareholders agreement, 211 and that the insertion of a foreign state-owned corporation as a shotgun joint venture partner "could have far reaching and unknown consequences to the joint venture given the sensitive geo-political environment."212

\section{DECISION}

Justice Wittmann (as he then was) declined to consider Lukoil's submissions touching on the substantive interpretation of the ROFR and change of control provisions. He noted that not only did the agreement provide for arbitration as the exclusive forum for resolving such 
matters (which proceedings were already underway), but also the determination of Lukoil's claims was well beyond the scope of the application before the Court. Justice Wittmann observed that the submissions of the parties seemed to suggest two different interpretations of the clauses in question, the resolution of which would require consideration of a number of complex and interrelated arguments, possibly with the assistance of parol or other evidence. ${ }^{213} \mathrm{He}$ also noted that the parties to the shareholders agreement expressly agreed to submit their disputes to arbitration for resolution and that "[j]udicial decisions and provincial legislation clearly support holding parties to arbitration as a dispute resolution method where they have agreed to it absent waiver or recognized exception."214

With respect to Lukoil's application for a stay of the final order approving the arrangement, the Court noted that if this application was granted, the arrangement would not be completed before the deadline prescribed in the arrangement agreement. CNPC would therefore be entitled to terminate that agreement, and there was no evidence before the Court that another offer would be forthcoming that would yield the US\$1.7 billion premium to PK's shareholders. According to the Court, if an arrangement that had been so overwhelmingly approved by PK's shareholders was not allowed to proceed, particularly in light of the speculative arguments advanced by Lukoil and the fact that the substantive claims were properly proceeding under arbitration, PK's shareholders could easily be prejudiced, perhaps irreparably. ${ }^{215}$ The Court further noted that if Lukoil was ultimately successful in the arbitration, there was nothing that would preclude Lukoil from exercising its rights to acquire PK's interest in Turgai after the arrangement has closed or, alternatively, being compensated by damages. ${ }^{216}$ Accordingly, the Court approved the arrangement.

\section{COMMENTARY}

The geo-political concerns raised by Lukoil as rationale for staying the arrangement until the conclusion of the arbitration were not well received by the Court. Given the Court's finding that there was no other justification for staying PK's application, the obvious benefit to its shareholders, and the fact that the shareholders agreement clearly called for Lukoil's claims to be resolved under arbitration proceedings already underway, the Court had no difficulty awarding PK a final order approving the arrangement.

Although the Court managed to avoid addressing Lukoil's allegations that its pre-emptive rights under the shareholders agreement were being breached, this is another example of a ROFR clause that does not clearly provide for all reasonably foreseeable eventualities and leaves the parties exposed to uncertain results in circumstances when absolute certainty is of critical importance. Under the shareholders agreement, a shareholder was clearly entitled to transfer its shares to any affiliate so long as the affiliate transferee was creditworthy and had sufficient experience in oil and gas operations. However, the shareholders agreement also provided that any change of control within a shareholder's "ultimate parent company" (defined as any party holding 50 percent or more of the voting shares of the shareholder) 
triggered a ROFR in favour of the other shareholder. Given that the predecessor to PKKR was a wholly-owned subsidiary of PK, a widely-held public corporation, it could be argued that Lukoil should have recognized that PKKR would be entitled to transfer its shares to PK (which it did) and that this transfer would arguably defeat the change of control provisions as they had theretofore applied to PKKR. Justice Wittmann's decision makes a brief reference to this argument and suggests that it was essentially the crux of PK's arguments before the arbitrator. Often, one small crack in the armour of a pre-emptive right that has otherwise been well conceived and drafted is all that is required to cripple it.

\section{Royalties}

\section{A. JAMES H. MEEK TRUST V. SAN JUAN RESOURCES INC. ${ }^{217}$}

\section{BACKGROUND}

In disputes involving non-payment or under-payment of royalties, the payee's claim often dates back several years. This case provides authority for when and how the payee's claim will be limited by the provisions of the Limitarions $A C t^{218}$ It also provides guidance on whether and what type of interest will be payable on unpaid royalties and when indemnification will be ordered as between working interest owners.

\section{FACTS}

The Meeks were three co-owners of a 3 percent gross overriding royalty (the GORR) of all oil, gas, and other hydrocarbons produced, saved, and marked from certain lands. In December 2002, they commenced a claim against San Juan Resources Inc. (San Juan) and Imperial Oil Resources Lid. (Imperial Oil) for non-payment or underpayment of the GORR on two wells on the lands dating back to 1988. In an earlier decision in the same action, LoVecchio J. had been asked to determine three issues: (1) whether the GORR was an interest in land; (2) whether it was payable on 50 percent or 100 percent of the working interest; and (3) whether it was to be calculated net of deductions. On those issues, LoVecchio J. ruled that the GORR was not an interest in land, that it was payable on 100 percent of the working interest, and that it was to be calculated net of deductions. The parties then returned to him in late 2004 to determine the remaining issues between them, and appealed his decision in 2005.

The GORR in this case was granted in 1952 and had been paid on various wells on the subject lands. The GORR had not, however, been paid on two wells that came on production in 1988. The Meeks sought payment of those outstanding royalties from 1988 to date and compound interest on the outstanding royalties, taking the position that they did not know, nor should they ought to have known, about the existence of their potential claim until May 2002 when Imperial notified them directly that, in various Court proceedings between Imperial and San Juan, the issue of a potential liability of San Juan to pay the GORR on the two wells was raised. 
San Juan took the position that the Meeks knew or ought to have known of their claim prior to 1 March 1999, and that the transitional provisions of s. 2(2) of the Limitations Act should therefore apply. If the transitional provisions were to apply, they would significantly limit the quantum of the applicants' damages. San Juan pointed out that throughout the period since the wells were brought on production, the Meeks had received various monthly payment reports and other correspondence that, with a bit of digging and inquiries to the AEUB, could have resulted in the applicants learning that the two wells were producing but that they were not receiving payment of the GORR on such production. San Juan further pointed out that, beginning in August 2000, Imperial began providing the Meeks with monthly royalty statements that included production volumes and royalty calculations on a well-by-well basis.

\section{DECISION}

Justice Hunt, writing for the Court of Appeal, identified the relevant transitional provision of the Limitations $\mathrm{ACl}$ as follows:

2(2) Subject to sections I I and 13, if, before March 1, 1999, the claiman knew, or in the circumstances ought to have known, of a claim and the claimant has not sought a remedial order before the earlier of

(a) the time provided by the Limitation of Actions Act, RSA $1980 \mathrm{cL}-15$, that would have been applicable but for this Act, or

(b) two years after the Limitations $A c t$, SA $1996 \mathrm{cL}-15.1$, came into fores,

the defendant, on pleading this Acl as a defence, is entitled to immunity from liability in respect of the claim. $^{219}$

On appeal, San Juan raised questions about the interpretation and application of the Limitations $A C t$, and the Meeks cross-appealed asserting that the trial judge selected the wrong interest rate under the Judgment Interest $A C^{220}$ and ought to have awarded compound rather than simple interest.

Justice Hunt found that LoVecchio J. mistakenly applied the common law test for discoverability from Maham v. Hindes, ${ }^{221}$ which states that "something ought to be discovered (or known) only if something had occurred which would place the applicants on inquiry and they did not follow through with an inquiry."222 Justice Hunt noted that "[t]he common law discovery principles have been ousted by statute and it is the factors in s. 3(1)(a) which apply to a s. 2(2) analysis.... The test for 'ought to have known' is that of 'reasonable diligence' analyzed in the light of the three s. 3(1)(a) factors." 223

$\begin{array}{ll}219 & \text { Ibid., s. 2(2) [emphasis added]. } \\ 220 & \text { Supra note } 37 . \\ 221 & 2001 \text { ABQB } 831,308 \text { A.R. I. } \\ 222 & \text { Supra note } 217 \text { al para. } 21 . \\ 223 & \text { Ibid. }\end{array}$


Justice Hunt reviewed the facts in light of the correct test to determine when the Meeks ought to have known of their claim. In this case Hunt J.A. found that s. $3(1)(a)(i)^{224}$ was the only relevant factor, posing the question, with the exercise of reasonable diligence when ought the Meeks to have become aware of the injury, i.e., the unpaid royalties?

Relying on LoVecchio J.'s analysis of the facts, Hunt J.A. concluded that although the trial judge applied the wrong test, he was not wrong to conclude that the Meeks ought not to have known of their claim prior to actual notification by Imperial Oil in May 2002. His analysis demonstrated that notwithstanding the information available to the Meeks and the change in format of the statements effective August 2000, nothing should have alerted the Meeks to a problem they did not earlier realize existed until they received Imperial Oil's May 2002 letter. He also noted that although a production audit might have revealed this problem in short order, the Meeks were not entitled to request one according to the agreement that created and governed that GORR.

Having found that the transitional provisions of the Limitations Act did not apply and that the Meeks first knew or ought to have known about their claim as of May 2002 (which was well within two years of the filing of their Originating Notice in this matter in December 2002), the Court then reviewed whether the applicants' claim was limited by the ten-year limitation period set out in s. 3(1)(b) of the Limitations Act. On the evidence before him, LoVecchio J. concluded that s. 3(3)(a) of the Limitations Act applied. ${ }^{225}$ Accordingly, Imperial Oil's failure to pay the required royalties was a continuing course of conduct or a series of related acts or omissions which resulted in the applicants' limitation date being reset and, as a result, the applicants were entitled to payment on production since 1988.

Justice Hunt disagreed, finding the applicable provision to be $s .3(3)(b)$ rather than $s$. $3(3)(a) .{ }^{226}$ Applying s. $3(3)(b)$ to the facts, Hunt J.A. concluded the following:

To summarize, the Meeks' claim arose for the purpose of s. 3(1)(b) when the first royalty payments were missed in 1988. Each non-payment theneafter gave rise to a separate claim. Their claim is barred for any payments due 10 years prior to the commencement of their action. 227

As a result, the Court concluded that the early failures to remit royalty payments are barred, but those within ten years of December 2002 are not.

Finally, on the interest and indemnity issues, the Court agreed with LoVecchio J., who found that the interest payable on the unpaid royalties should be simple and not compound interest and, based on the specific wording of the Farmout Agreement and a settlement

Section 3(1)(a)(i) states: "Subject to section 11 , if a claimant does not seek a remedial order within (a) 2 years after the date on which the claimant first knew, or in the circumstances ought to have known. (i) that the injury for which the claimant seeks a remedial order had occurred." on any number of breaches of duty, resulting from a continuing course of conduct or a series of related acts or omissions, arises when the conduct terminates or the last act or omission oceurs." arises when the conduct, act or omission occurs." 
agreement as they applied to the facts of this case, Imperial Oil was entitled to indemnity from San Juan.

\section{COMMENTARY}

This case is clear, current authority on when and in what circumstances a royalty holder's claim for unpaid royalties will be limited by the provisions of the Limilations Act.

\section{B. MISSILINDA OF CANADA LTD. V. HUSKY OIL OPERATIONS LTD. 228}

\section{BACKGROUND}

This dispute concerned whether a lessee is entitled to deduct expenses for the cost of processing and transporting the oil before calculating royalty payments owed to the lessor.

\section{FACTS}

Pursuant to a lease dated 9 October 1984 between Missilinda of Canada Ltd. (Missilinda) as lessor and Husky Oil Operations Ltd. (Husky) as lessee, Husky produced oil from a well located on the subject leased lands in Saskatchewan. The relevant royalty provisions from the lease read as follows:

The Lessor does hereby reserve unto himself a gross royalty of Seventeen \& One Half (17 1/2\%) per cent of the leased substances produced and marketed from the said lands. Any sale by the Lessee of any crudc oil, crude naphtha, or gas produced from the said lands shall include the royalty share thereof reserved to the Lessor, and the Lessee shall account to the Lessor for his said royalty share in accordance with the following provisions, namely:

\footnotetext{
The Lessee shall remit to the Lessor, on or before the 25th day for cuch month, (a) an amount equal to the current market value at the wellhead on the date of delivery of Seventeen \& One Half (17 1/2\%) per cent of the crude oil and crude naphtha produced, saved and marketed from the said lands during the preceding month, and (b) an amount cqual to the currem market value at the wellhead on the date of delivery of Seventeen \& One Half $(17 \mathrm{l} / 2 \%$ ) per cent of all gas produced and marketed from the said lands during the preceding month. ${ }^{229}$
}

Obviously, the crude oil produced by Husky from the lands was not sold or even saleable at the wellhead. More specifically, there was no market for the crude oil at the wellhead and the crude oil was required to be moved downstream for processing and transportation to the point of sale. The dispute between the parties was, therefore, whether the words "current market value at the wellhead" found in the lease allowed Husky to deduct processing and transportation expenses for the purposes of calculating the amount of the royalty payable to Missilinda. 


\section{DECISION}

In finding that Husky was entitled to deduct processing and transportation expenses before paying on the royalty, Keyser J. relied on the decision of the Alberta Court of Queen's Bench in Acanthus Resources Lid. v. Cunningham ${ }^{230}$ whercin Hart J. stated:

It has long been recognized both in the oil and gas industry as well as in law, however, that a value can be established at various points upstream of the market or point of sale by deducting costs incurred downsircam of any point to the actual point of sale. In this case, such costs downstream of the wellhead are essentially the treating costs incurred to remove water from the crude oil, the costs of storing the treated oil in the battery tanks and finally the cost of trucking the oil to market.

J interpret the royalty provision in the Leases to mean that the royalty is to be determined at the wellhead and that in so doing costs properly incurred downstream of the wellheal to the point of sale must be borne proportionally between the Lessors and the Lessee. Sinee this is a $17 \%$ royalty this same percentage of such costs are for the account of the Lessors. These costs, of course, specifically include the treating costs which are directly at issue as well as the trucking costs to which no objection is taken by the L.essors. ${ }^{231}$

In making its determination, the Court specifically rejected Missilinda's assertion that the wording of the lease was ambiguous, such that it should be interpreted against Husky. Justice Keyser also stated that even if he had found the royalty concession to be ambiguous, he would have preferred the testimony of John Ballem, Q.C., who provided expert evidence to the Court confirming the principle of downstream deductibility. Finally, Keyser J. also considered two divergent lines of case law authority out of the United States. The first, referred to as the "Colorado" line of cases, stood for the proposition that it is generally not appropriate to deduct such costs. The other, called the "Michigan" line of cases, stood for the opposite proposition. The Court held that the Michigan line of cases was more consistent with generally accepted practices in Canada and was to be followed here. Lastly, the Court rejected Missilinda's submission that the lease contained an implied term that the lessee was required to produce a marketable product for the lessor. The Court noted that no Canadian case was provided to show a recognition of such an implied covenant and held that no such implied term should originate here.

\section{COMMENTARY i}

This case reaffirms the law in Canada on the deductibility of downstream process and transportation costs for the purposes of calculating royalty payments. 


\section{R.W. MITTEN ENTERPRISES LTD. $V$. COMPUTERSHARE TRUST CO. OF CANADA ${ }^{232}$}

\section{BACKGROUND}

In this decision the Alberta Court of Appeal revisits its earlier decision in Guaranty Trust Co. $v$. Hetherington ${ }^{233}$ on slightly different facts.

\section{FACTS}

In Hetherington, the Court of Appeal determined that a gross royalty trust agreement (GRTA) did not continue to bind an owner in circumstances where there had been an existing lease of mineral rights at the time the GRTA was executed (which lease was therefore subject to the GRTA), but which had expired on its own terms. In this case, the GRTA was executed before the mineral lease in question was entered into. Subsequently, that lease also expired on its own terms. The applicant mineral rights owner took the position that the decision in Hetherington applied in these circumstances notwithstanding the slightly different facts, and that he was therefore no longer bound by the GRTA. The respondent trust company took the position that the decision in Hetherington was distinguishable due to the different facts and the fact that the mineral rights owner was required to reserve the gross royalty to the trust company with any new lease he entered into with respect to the lands. In both this case and Hetherington, the relevant provision of the applicable GRTA was the same. ${ }^{234}$

\section{DECISION}

The Court of Appeal affirmed the trial judge's decision in favour of the owner, stating as follows:

Clause 25 contemplates two eventualities: (1) where there is no lease in existence, and (2) where there is a lease in existence that has been cancelled. The final words of Clause 25 apply to both eventualities. This court in Hetherington did not find the words "any lease" referred to in the final words of Clause 25 helpful in finding a continuing obligation. Indeed, it is not suggested that in a Hetherington-type situation, where a cancellation occurs, the parties would be required to continuc to protect the royalty in all future leases. We see no reason to give those words that meaning here.

This court's interpretation of the GRTA in Hetherington is not distinguishable and is applicable here. The assignor transferred to the Mitten trust the 12 1/2 per cent royalty under a lease to be executed. Once such a lease was executed and expired of its own terms, the trust had no furher interest. ${ }^{235}$

25. OWNER'S COVENANT RE LEASE. The Owner hereby covenants and agrees with the Trustee that, in the event that any lease that may be in existence as at the date of this Agreement is cancelted for any reason or in any event that no lease is in existence as at the date of this Trust Agreement, he shall and will in negotiating any lease or other instrument for developing the said lands reserve unto the Trustee the full $12 \% \%$ Gross Royalty hereby assigned to the Trustec. 


\section{COMMENTARY}

This case reaffirms Hetherington as the law in Alberta regardless of whether the subject mineral lease was entered into before or after the GRTA.

\section{SET-OFF}

\section{A. RE ANDROSCOGGIN ENERGY LLC $C^{236}$ \\ 1. BACKGROUND}

This decision is the most recent pronouncement in Canada on the elements that must be found in a forward commodity contract in order for that contract to qualify as "eligible financial contracts" (EFCs) for the purposes of the CCAA. ${ }^{237}$ Here, the Ontario Court of Appeal agreed with the Alberta Court of Appeal decision in Re Blue Range Resource Corp. ${ }^{238}$ in not drawing a distinction between physically-settled and financially-settled transactions as the basis for determining whether a contract is an EFC.

\section{FACTS}

Androscoggin Energy LLC (Androscoggin), a co-generation business, was a party to various long-term, fixed-price contracts with the appellant gas suppliers whereby the appellants supplied gas to Androscoggin's co-generation plant in Maine. Androscoggin became insolvent and commenced bankruptcy proceedings in the United States. Concurrently, it also obtained an ex parte order in Ontario under s. 18.6 of the $C C A A$, which recognized the proceedings in the United States as a "foreign proceeding" and stayed all actions against Androscoggin, including the appellants' rights to terminate the gas supply contracts or to en force their contractual rights.

Various parties with forward gas supply contracts with Androscoggin applied for a declaration from the Ontario court that their contracts were exempt from the court-ordered stay under the CCAA exemption for EFCs. At trial, Farley J. found that there is a distinction between physical and financial contracts and dismissed the plaintiffs' application, finding that the contracts in question were not EFCs for the purposes of the $C C A A$. In doing so, Farley J. stood in direct contrast to the $\mathbf{2 0 0 0}$ decision of the Alberta Court of Appeal in Blice Range. Instead, Farley J. favoured the trial decision in B/we Range, which emphasized the word "financial" in "eligible financial contracts," stating that even if the supply contracts were considered EFCs, based on their own terms they could not be terminated merely as a result of Androscoggin's insolvency. 


\title{
3. DI:CISION
}

The Ontario Court of Appeal agreed with the Alberta Court of Appeal's interpretation of s. 11.1(1) of the CCAA and rejected the distinction between physically-settled and financially-settled contracts as the basis for determining whether a contract is an EFC. Writing for the Court, Weiler J.A. stated that:

\begin{abstract}
The contracts in issue before Fruman J.A. [in Blue Range] scrved a financial purpose unrelated to the physical settlement of the contracts. The reasons in Bluc Ronge indicate that the contracts liruman J.A. examined enabled the parties to manage the risk of a commodity that flucluated in price by allowing the counterparty to terminate the agrecment in the event of an assignment in bankruptcy or a $C C A A$ proceeding, to offset or net its obligations under the contracts to determine the value of the amount of the commodity yet to be delivered in the future, and to re-hedge its position. Unlike the contracts found to be EFCs in Blue Range, supra, the contracts in issue here possess none of these hallmarks and cannot be characterized as EFCs. llowever, mere pro forma insertion of such terms into a contract will not result in its automatic characterization as an EFC. Regard must be had to the contract as a whole lo determine its character. ${ }^{239}$
\end{abstract}

The counterparties argued that although they could not terminate the supply contracts based upon Androscoggin's insolvency, they could terminate them at common law for fundamental breach. The Court held that Farley J. had ruled correctly that the rights of the counterparties were not affected by the characterization of the supply agreements; rather, the terms of the contracts themselves did not entitle the appellants to terminate the contracts.

\section{COMmentary}

While the Court agreed with the Alberta Court of Appeal decision in Blue Range, it took a narrower view than the Alberta Court of Appeal on which contracts qualify as EFCs, indicating that physically-settled contracts will only be EFCs if they serve a financial purpose unrelated to the physical settlement of those contracts. The Court held that, in determining whether or not a commodity contract serves a financial purpose, the contract as a whole must be analyzed to determine its character.

\section{B. 918339 ALBERTA LTD. V. 569244 BRITISH COLUMBIA LTD. ${ }^{240}$}

\section{BACKGROUND}

This case concerned a property (the Property) with a "tortured development history" that was also the subject of several proceedings in the courts of British Columbia and Ontario. Since the late 1990s, the Government of British Columbia had been interested in acquiring a portion of the Property from its owners, the McLaughlin family, to preserve it as an ecological wetland; the owners, on the other hand, along with certain investors, were interested in developing whatever portion of the Property remained available to develop after the sale. 


\section{FACTS}

The Government of British Columbia advanced $\$ 25$ million secured by a mortgage with an intent to buy a significant portion of the Property. When the mortgage went into default, the government commenced proceedings to foreclose on the Property.

Pursuant to a court order in the foreclosure proceedings, the mortgage was discharged upon payment into trust of \$21 million. 918339 Alberta Ltd. (918339) subsequently petitioned the Court for payment out of these trust funds of 516 million as the principal amount owing to it by the respondents under a mortgage loan. 918339, as petitioner, submitted that this amount, which was the original principal amount of the loan plus interest and bonus, was due and owing and should therefore be ordered to be paid to it as a debt presently due.

569244 British Columbia Ltd. (569244) and other respondents opposed the plaintiffs application on the basis that they should be entitled to equitable set-off arising out of a possible settlement in a related matter, since 918339 could potentially be held liable in the related matter to pay a sum of money to the respondents.

918339 argued that it had no present liability to make any payment to the respondents in connection with the related matter, and that it was unlikely that there would be any liability in the foreseeable future. Further, 918339 maintained that there was no authority in Canada to support the proposition that a possible future contingent claim or payment may be raised by way of equitable set-off against a claim for judgment for a liquidated amount presently due and owing. The chambers judge disagreed with 918339 , holding that there was a bona fide triable issue in relation to the claims advaneed by the respondents, and referred the hearing of the petition to the trial list. 918339 appealed that decision to the British Columbia Court of Appeal.

\section{DECISION}

The Court of Appeal briefly reviewed the terms of the settlement agreement, noting that the agreement provided that, in consideration of the settlement, the respondents would make a future payment of $\$ 30$ million out of revenues from the future development of the Property over a reasonable period of time.

The Court noted that all parties agreed that nothing was currently owed pursuant to the settlement agreement, and the respondents acknowledged that there was an aspect of contingency to the indemnity claim (although they claimed that it was virtually certain that profit levels would be achieved during the development of the land that would trigger the appellant's obligation to pay). 918339 submitted that the settlement agreement created nothing more than a contingent obligation and that it would be inappropriate to delay payment to it of the sum certain presently owed by the respondents on the basis of a speculative and contingent claim.

In allowing the appeal, the Court held that the existence of a possible future claim or payment does not rise to the level of certainty necessary to support a defence of equitable set- 
off. The Court noted that any future obligation on the part of 918339 to make payment under the settlement agreement depended upon a number of contingencies, including the course of the future development of the Property and the achievement of certain financial results. Accordingly, the Court held that "[g]iven the high level of uncertainty of the potential claims for indemnity or damages, it would ... be manifestly unjust to hold up on this account payment of the liquidated sum presently owed to the appellant."241

\section{COMMENTARY}

The Court's decision provides some helpful clarity to the law of equitable sel-off. It has always been open to a party with an unliquidated claim to be granted equitable set-off (assuming the remedy's other tests of mutuality and connection are met), but it is now much clearer that it is not available for contingent or speculative future claims.

\section{TAXation}

\section{A. Canada TRUStco Mortgacie Co. V. CANADA ${ }^{242}$ \\ 1. BACKGROUND}

This decision, together with the decision of Mathew $v \cdot R \cdot .^{243}$ discussed below, represent the first time the Supreme Court of Canada has had the opportunity to consider the application of the general anti-avoidance rule (the GAAR) contained in s. 245 of the Income Tax Act. ${ }^{244}$ Specifically, this case addresses whether the usual result of the capital cost allowance (CCA) provisions of the ITA can be re-characterized by the GAAR in the absence of real "economic cost."

\section{FACTS}

The taxpayer was a Canadian financial institution that held a large portfolio of loans and leases. In its 1996 taxation year, the taxpayer engaged in a sale-leaseback transaction comprised of a number of steps. First, the taxpayer purchased trailers from a U.S. vendor, using money borrowed from a Canadian chartered bank, together with cash on hand, to fund the purchase price. Following the purchase, the taxpayer leased the trailers to an intermediary who, in turn, subleased them to the U.S. vendor. The U.S. vendor then prepaid its obligations under the sublease. The intermediary placed a portion of the prepaid lease payments on deposit with the bank in question and the remainder was used to purchase a government bond that was pledged in favour of the taxpayer in respect of the intermediary's purchase option under the lease with the taxpayer. As a final step, the taxpayer assigned the lease payments receivable from the intermediary to the bank to be applied against the taxpayer's loan instalments. As a result of the lease prepayment and the various security arrangements, the taxpayer bore little "economic risk" regarding the purchase price of the trailers.

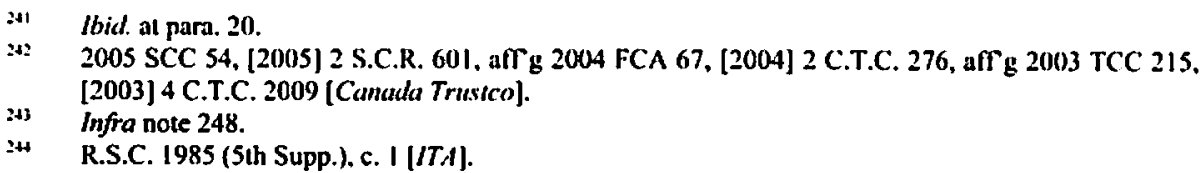


Pursuant to s. 20(1)(a) of the ITA and the rules in the Regulations, the taxpayer claimed CCA in respect of the trailers, which it deducted against leasing income from the trailers, as well as income from other leasing sources. The Minister of National Revenue applied the GAAR to deny the CCA claimed by the taxpayer because, in its view, the taxpayer did not incur any cost to acquire the assets since the taxpayer bore no "economic risk" in relation to the purchase price of the trailers. The Tax Court of Canada set aside the Minister's decision. and the Federal Court of Appeal rejected the Minister's appeal.

\section{DECISION}

Writing jointly for the Court, McLachlin C.J.C. and Major J. began by stating that, in contrast to many provisions of the ITA, the GAAR is a broadly-drafted section, the intent of which is to re-characterize transactions that technically comply with the provisions of the ITA on a literal or textual interpretation, but which constitute abusive tax avoidance. In addition to these general comments, the Court set out the three requirements that must be established to permit application of the GAAR: (1) there must be a tax benefit resulting from a transaction or part of a series of transactions (ss. 245(1) and (2)): (2) the transaction must be an avoidance transaction in the sense that it cannot be said to have been reasonably undertaken or arranged primarily for a bona fide purpose other than to obtain a tax benefit; and (3) the transaction must involve abusive tax avoidance in the sense that it cannot be reasonably concluded that a tax benefit would be consistent with the object, spirit, or purpose of the provisions relied upon by the taxpayer. ${ }^{245}$

Further, the Court also set out six guiding principles to be used in applying the GAAR. After discussing as its first point the three requirements above that would invoke a consideration of the transaction under the GAAR, the Court succinctly summarized these six principles as follows:

2. The burden is on the taxpayer to refute [requirements] (1) and (2). and on the Minister to establish [requirement] (3).

3. If the existence of abusive tax avoidance is unclear, the benefit of the doubt goes to the taxpayer.

4. The courts [should] proceed by conducting a unilied textual, conlextual and purposive analysis of the provisions giving rise to the tax benefit in order to determine why they were put in place and why the benefit was conferred / with the goal of arriving at a purposive interpretation that is harnonious with the provisions of the Act that confer the tax benefit, read in the context of the whole Act.

5. Whether the transactions were motivated by any economic, commercial, family or other non-tax purpose may form part of the factual conlext that the courts may consider in the analysis of abusive tax avoidance allegations... However, any linding in this respect would form only one part of the underlying facts of a case, and would be insulticient by itself to establish abusive lax avoidance...

6. Abusive tax avoidance may be found where the relationships and transactions as expressed in the relevant documentation lack a proper basis relative to the object, spirit or purpose of the provisions that 
are purported wo confer the tax benefit, or where they are wholly dissimilar to the relationships or transactions that are contemplated by the provisions.

7. Where the Tax Court judge has proceeded on a proper construction of the provisions of the Income Tax $A C t$ and on lindings supported by the evidence, appellate tribunals should not interfere, absent a palpable and overriding error. ${ }^{2+6}$

In the course of linding in favour of the taxpayer and applying the principles set out above, the Court concluded that the purpose of the CCA provisions, as they applied to saleleaseback transactions, was to permit a deduction based on cost, and that this purpose clearly emerged from the scheme of the CCA provisions within the $\mathrm{Act}^{2+77}$ In the Court's view, the sale-leaseback transaction entered into by the taxpayer was not so dissimilar from an ordinary sale-leaseback transaction to cause the transaction to fall outside of the object and spirit of the CCA provisions.

\section{COMMENTARY}

The Court has done an excellent job of concisely outlining guiding principles to be used in applying the GAAR. However, these guiding principles do not help achieve the level of consistency, certainty, and predictability that many taxpayers and their advisors were hoping would be achieved by the first pronouncement on the GAAR by the Supreme Court. Prior to this decision, a tax-motivated transaction could be re-characterized under the GAAR only if the transaction was contrary to a clear and unequivocal policy contained within the ITA. Now, the Supreme Court of Canada has stated that the GAAR will apply where the abusive nature of a transaction is "clear." The applicable standard now appears to be broader given that the Court has not provided any guidance on exactly how clear the abusive nature of the transaction must be for the GAAR to apply.

B. MATHEWV.CANADA ${ }^{2+8}$

1. BACKGROUND

This case is the companion case to Canada Trusico, ${ }^{249}$ and addresses the issue of whether what were formerly s. $18(13)$ of the $I T A^{250}$ and s. 96 of the ITA permit arm's length parties to purchase tax losses. 


\section{FACTS}

Standard Trust Co. (Standard Trust) was in the business of lending money. When Standard Trust became insolvent, it sought to maximize the realization of its assets by devising a plan to transfer its unrealized losses to arm's length partics. To do so, it first packaged mortgages with unrealized losses into a partnership with which it did not deal with at arm's length. By virtue of the stop-loss rule in s. 18(13) of the ITA. Standard Trust was precluded from recognizing the losses realized on the transfer of the mortgages to the partnership, and the partnership added the denied losses to the cost base of the mortgages it acquired. In furtherance of its plan, Standard Trust subsequently sold the partnership interest to an arm's length purchaser, OSFC Holdings. Subsequently, OSFC Holdings syndicated its interest in the partnership through a general partnership, SRMP, and limited partnership interests in SRMP were purchased by the taxpayers. At the end of the partnership's fiscal year, the losses realized on the mortgages were first allocated to the partners of the partnership, including SRMP, who subsequently allocated its shares of the losses to its partners, including the taxpayers. The Minister reassessed the taxpayers under the GAAR to deny the partnership the losses claimed.

\section{DECISION}

The Court referred to the guiding principles outlined in its companion decision of Canada Trusico. The Court noted that two of the three requirements for the application of the GAAR, being a tax benefit and a tax avoidance transaction, were conceded by the taxpayers. The remaining issue was whether the transactions resulted in abusive tax avoidance, and to determine this the Court looked to the text, context, and purpose of the provisions at issue.

After the Court's review of the text and context of the provisions proved unhelpful, it focused on the purposes of ss. 18(13) and 96 of the ITA. With respect to s. 18(13), the Court found that its purpose was to prevent a taxpayer who is in the business of lending money from claiming a loss upon the superficial disposition of a mortgage or similar non-capital property. This purpose was achieved by confining the loss that would ordinarily be claimed by the transferor to a non-arm's length transferee. The reason the loss is preserved is because the property is generally under the control of the transferor before and atter the transfer and because of the non-arm/s length relationship between the transferor and the transferee. The Court noted that absent a non-arm's length relationship between the transferor and the transferee, there is no reason for $\mathrm{s} .18(13)$ to apply.

Turning to s. 96(1) of the $I T A$, the Court stated that the rules in s. 96 are based on the assumption that the partners of the partnership carry on business in common in a non-arm's length relationship. Further, the purpose for permitting the broad sharing of losses between partners is to promote an organizational structure that allows partners to carry on a business in common, in a non-arm's length relationship. These observations, taken together, suggested to the Court that ss. 18(13) and 96 were not intended to allow losses to be preserved and transferted from a taxpayer 10 an arm's length person and that the partners in the transferee partnership must pursue a business activity in common, other than to transfer the particular loss. 
The Supreme Court then proceeded to apply this interpretation of the ITA to the facts in Mathew. In its view, the only reasonable conclusion was that allowing the taxpayers to claim the partnership losses would defeat the purposes of ss. 18(13) and 96 of the ITA. According to the Court, these provisions, interpreted textually, contextually, and purposively, should not permit arm's length persons to "purchase" tax losses preserved by s. 18(13) of the ITA because a loss is preserved under this latter section on the assumption that it will be claimed by a taxpayer who does not deal at arm's length with the transferor.

\section{COMMENTARY}

Curiously, the Court did not refer to any extrinsic aids in assessing the purpose of ss. 18 (13) and 96 of the ITA. Moreover, the Court's decision in Mathew arguably added little to brighten the line between legitimate tax planning and abusive tax avoidance, although this may have been difficult to do with any degree of thoroughness given the narrow scope of the facts before it. In that regard, Mathew does make it clear that loss trading likely constitutes "abusive tax avoidance" for the purposes of the GAAR test set out in Canada Trustco, except where such trading is expressly provided for in the ITA.

\section{INJUNCTIONS}

\section{A. WELLTEC APS V. PRECISION DRILLING CORP. ${ }^{23 !}$ \\ I. BACKGROUND}

Injunction applications arc, except in rare circumstances, determined on the basis of a tripartite test. It should be noted that the individual components of the tri-partite test, and the thresholds required to be met by an applicant for an injunction, vary from case to case depending on the nature of the injunction sought (mandatory or prohibitive) and also the impugned activity sought to be enjoined or performed. In this case, the applicants sought a prohibitive injunction to restrain, among other things, patent breach and passing-off. The reader will note that the first part of the tri-partite test was measured on the basis of whether a "serious issue" had been shown. The second part of the test, requiring the applicant to show irreparable harm, was affected by the nature of the activity, i.e., the tort of "passing-off." Interestingly, it would appear that irreparable harm is more easily proved in the context of that type of claim.

\section{FACTS}

The plaintiffs, Welltec ApS, a Danish company, and Welltec Canada Inc., its whollyowned Alberta subsidiary (collectively, Welltec), sued Precision Drilling Corp. (Precision Canada) and its subsidiary Precision Drilling Technology Services Group Inc. (Precision Alberta). Welltec also named Precision Drilling Technology Services GmbH, a German subsidiary of Precision Alberta (Precision Germany), as a defendant, but no relief(other than document production) was sought against Precision Germany. 
The case concerned a down-hole tool called a "Well Tractor" that Welltec ApS invented to deliver unique servicing capabilities to oil and gas wells. The plaintiffs alleged that Precision Canada and Precision Alberta had caused Precision Germany to copy the plaintiffs' designs for the Well Tractor and to manufacture competing units from those designs. The plaintiffs claimed that Precision Canada and Precision Alberta: (1) had breached express and implied terms of several contracts by manufacturing the competing well tractor; (2) had induced Precision Germany to breach its contracts with Welltec ApS; (3) had breached obligations of good faith; (4) had breached a United States patent ${ }^{25}$ held by Welltec $A p S$ in respect of the Well Tractor; (5) were passing-off their well tractors by using the plaintiff's' trademarks and distinguishing features; and (6) had interfered in the plaintiffs' economic relations with customers causing them to lose business in Canada.

The plaintiffs brought an application in the Alberta Court of Queen's Bench to enjoin Precision Canada and Precision Alberta from manufacturing, exporting, marketing, and using copied well tractors. No injunction was sought against Precision Germany, primarily because of the jurisdictional limits of such in personam remedies as against a company located outside of Alberta. ${ }^{253}$

In response to the plaintiff' injunction application, the defendants sought to have the plaintiffs' claims summarily dismissed.

\section{DECISION}

On the summary dismissal application, most of the defendants' claims were dismissed. The plaintiffs' injunction application was granted.

a. Summary Dismissal Application

The Court dealt first with the defendants' summary dismissal application.

\section{Contractual Claims}

The Court considered four different contracts and negotiations toward a fifth contract. Neither Precision Canada nor Precision Germany was a party to any of the four contracts. Precision Alberta was party to only one of the four contracts, but no term of that contract had been breached. The negotiations lowards the fifth contract had not resulted in a contract. As neither Precision Canada nor Precision Alberta were privy to the only contracts said to have been breached, the contractual breach claims were summarily dismissed. 


\section{(ii) Inducing Breach of Contract}

The Court was very succinct in its analysis of this cause of action. As the Court found that no contract to which any of the Precision entities were party had been breached, it logically held that the tort of inducing such a breach could not be maintained.

\section{(iii) Good Faith Claims}

In one line of the reasons, the Court also dispensed with the claim that there had been a breach of the duty of good faith. The Court held that, "without a contract, there can be no breach of good faith." ${ }^{254}$ This is somewhat surprising given that the doctrine of good faith has in other circumstances been held to exist notwithstanding the existence of a contract (for example, in the context of pre-contractual negotiations) and is an area of the law that continues to develop.

\section{(iv) Patent}

As noted above, the plaintiff' claim was founded on the existence of a United States patent. While an application for a Canadian patent had been made, no such patent had been issued. The Court also noted the prospective tenor of the statement of claim: "The claim reads that upon issuance the patent will have been infringed. Because this all occurs in the future, there is no cause of action."

\section{(v) Passing-Off}

The Coun permitted the claim for passing-off to proceed. As a tort, this cause of action does not require a contractual foundation to succeed. Citing the Supreme Court of Canada in CIBA-Geigy Canada Lid. v. Apotex Inc.. ${ }^{256}$ the Court noted that to successfully bring a claim for passing-off, the claimant must: (1) have goodwill in the trademark or the distinguishing features of the goods at issue; (2) demonstrate that the public has been deceived due to a misrepresentation as to the maker of the goods; and (3) have suffered actual or potential damages. ${ }^{237}$

\section{(vi) Interference in Economic Relations}

Having found that the tort of passing-off could not be summarily dismissed, the Court declined to assess the claim for the tort of interfering in economic relations. The Court held that the existence of a justiciable claim for passing-off was sufficient to meet the first part of the tri-partite injunction test. However, the Court did note, in obiter, that "[a]n intention to injure is central to the tort," and that "[t]here are no facts supporting such a claim now so that the neat question would be whether a judge can infer an intention to harm from an intention to competc."2sk

\begin{tabular}{|c|c|}
\hline 294 & Sipra note 251 at para. 38. \\
\hline 3 & Mid. at para. 39. \\
\hline 50 & $\begin{array}{l}\text { [1992] 3 S.C.R. } 120 . \\
\text { lbid. at I32. }\end{array}$ \\
\hline & Stupra not \\
\hline
\end{tabular}




\section{b. Injunction Application}

The Court then considered the tri-partite injunction test in the context of the plaintiffs' application for an interim injunction.

\section{(i) Serious Issue}

The foregoing analysis was, in addition to being an assessment of the summary dismissal application, a prelude to the injunction application, in that it provided an assessment of the first part of the tri-partite test. As noted above, the Court did not dismiss the claim for the tort of passing-off and this was the foundation for finding that the applicant had, in fact, demonstrated the existence of a serious issuc. The balance of the injunction analysis proceeded on the merits of the injunction in the context of that particular claim.

\section{(ii) Irreparable Harm}

The Court relied on Edmonton Norlhlands v. Edmonton Oilers Hockey Corp. ${ }^{259}$ in which it was held that the applicant "does not have to establish that damages will be inadequate, but merely that doubt exists as to whether damages will be adequate in the circumstances." 200 The Court noted that there was evidence of a well-established business being operated by Welltec and that "[t]here is evidence that the Well Tractors are unique and of superior performance."261 The defendants had not presented any evidence as to the quality of the "Precision Trac," the defendants' version of the machine. As a result, the Court held that "[t]he potential that a machine of lesser quality and probably indistinguishable from the Well Tractor will risk Welltec's goodwill leads me to conclude that there is serious doubt that damages would be an adequate remedy."26"

\section{Balance of Convenience}

The evidence before the Court showed that the defendants had made only four machines and had the ability to make only two more, whereas Welltec had numerous machines and had been in the business for over ten years. Based on this factor alone, the Court held that "the balance [of convenience] clearly favours Welltec." 263

\section{COMMFNTARY}

In the present case, the Court found that the first part of the test required the applicant to show a "serious issue" (however, as discussed below, other forms of injunction require the applicant to meet a higher standard). Courts have frequently commented that the burden to show a "serious issue" is quite low and, as a result, many applicants are lulled into the idea that little attention is needed to meet this part of the test. But in this case, the defendants took a more aggressive stance in resisting the plaintif's' application and sought to prove that there 
was no serious issue by making a cross-application for summary dismissal of the applicant's claims. That strategy was largely successful: the respondent succeeded in striking out all but one of the claims against it. Thus, Welltec provides a good example of how a respondent to an injunction application can take a more aggressive posture and attempt to prove that no serious issue is shown.

Another interesting aspect of this case is the Court's consideration of the "De Mattos principle" arising from De Matros v. Gibson ${ }^{26-1}$ in the context of its analysis of the summary dismissal application, which also formed its analysis of the first part of the tri-partite test. The general principle of De Mattos is that, where someone acquires property from another (either by sale or gift) with knowledge of a previous contract made by the seller/grantor with a third party that the property is to be used for a particular purpose in a specified manner, the acquirer is bound not to use the property in a manner inconsistent with that contract. The Court then considered three recent cases in which the De Mattos principle was considered: Canadian Brotherhood of Raihwy Transport Workers v. B.C. Air Lines Lid.; ${ }^{265}$ Law Debenture Trust Corp plev. Ural Caspian Oil Corp Lid.; $;^{26 t}$ and Silver Butle Resources Lid. v. Esso Resources Camada Lid. ${ }^{267}$

What is perhaps surprising is that the Court did not go on to consider expressly in its analysis of the first part of the tri-partite injunction test the effect of its previous analysis of the De Mattos principle. The Court had noted in the context of the summary dismissal application that the principle could form the basis of a negative injunction, but not a basis to extend to the acquirer's contractual obligations. Unfortunately, however, the Court did not consider the effect of its previous consideration of De Mattos in the context of the application for the negative injunction soughe by the plaintifts.

(1958, 1959), 4 DeG. \& J. 276|De Mathos).

(1970), 14 D.L.R. (3d) 69I (B.C.S.C.). The British Columbia Supreme Court applied De Mattos in holding that a collective bargaining agreement continued to be in force against a purchaser, even though the purchase was of assets and not of the previous employer entity itself.

[1993] 2 All E.R. 355 (Ch.D.). The English Chancery Division acknowledged the existence of the De Mattos principle, but held that it was intended to grant a negative injunction to restrain a purchaser from doing that which was inconsistent with the performanee of the original contract. The Court noted this distinction and concluded that $D e$ Mattos is not a vehicle by which one can impose contractual obligations where nonc exist.

(1994). 19 B.1..R. (2d) 299 (B.C.S.C.). The Court noted here that a covenant in restraint of trade is assignable in two cireumstanees: (1) the lirst. called the "conditional benefivburden principle," arises where an assignee lakes the benefit of a contract and the benefit is conditional upon the performance of an obligation, in which case llie assignee must also take the burden with the benefit; and (2) the second, called the "pure benefit/burden principle," arises where the benelit is independent of the burden, but the circumstances are such that the assignee is nevertheless saddled with the burden. The Cour noted, however, that there was no assignment or novation of the contract in the present case and, thus, neither benefitburden principle applied. 


\section{B. L.P.I. V.000 ALBERTA LTD. ${ }^{268}$}

\section{BACKGROUND}

In a confidential negotiation involving the potential purchase and sale of lands, two parties signed a letter of intent: One of the parties claimed that the letter of intent constituted a binding agreement; the other party believed otherwise. This case concerns the question of whether the party claiming the letter of intent was binding could thereafter file a caveat to protect its alleged interest in the lands in question without breaching express confidentiality provisions pertaining to the negotiations.

\section{FACTS}

Two parties, whose identities were ordered to be kept secret by the Court, had participated in negotiations for the purchase and sale of certain lands. The negotiations culminated in the parties signing a letter of intent. At the outset of their negotjations, the parties signed a confidentiality agreement that provided that the purchaser would not disclose to any third party any of the details surrounding the possible transaction or the fact that they had entered into negotiations in connection with the possible transaction.

The purchaser took the position that a binding agreement had been made between the parties. The vendor disagreed, saying that the letter of intent was non-binding. Pending a determination of that issue, the purchaser filed a caveat against the vendor's lands claiming an interest "as purchaser in lands owned by [L.P.1.], pursuant to a binding letter of intent dated 31 July $2001 . " 269$ !

The vendor believed that the registration of the caveat by the purchaser constituted a breach of its covenants under the confidentiality agreement. The Alberta Court of Queen's Bench granted an injunction against the purchaser requiring the purchaser to remove its caveat. The purchaser appealed.

\section{DECISION}

The appeal was dismissed. The Alberta Court of Appeal held that the granting of an injunction is a discretionary remedy and that, therefore, on appeal an appellant must show that there was an "error in law or principle contributing to the result, or [a] palpable and overriding error in fact."270 The Court held that the purchaser failed to meet this high standard.

The Court found that there had been a clear breach of the non-disclosure covenant. Where there is a "clear breach of a clear covenant," the tri-partite test ordinarily applicable to injunctions is "relaxed" inasmuch as irreparable harm is presumed from the breach. The

27) Ibid. at para. 3, quoting Edmonton Northlands v. Edmonton Oilers Hockey Corp. (1994), 149 A.R. 92 al para. 2 (C.A.). 
Court concluded that if the purchaser's caveat was allowed to remain on title to the vendor's lands, the purchaser's covenant in the confidentiality agreement would have been rendered meaningless.

\section{COMmentary}

Clearly, the purchaser put itself in a "Catch-22" by agreeing that it would keep the negotiations confidential without reserving to itself the right to file a caveat if it believed a binding agreement had been reached.

It is imporant to note that the fundamental issue in this case involves a prohibition against disclosure of the parties' negotiations towards reaching an agreement. If and when an agreement was reached, the confidentiality clause could arguably not have prohibited the registration of the purchaser's caveat. As a result, a critical issue was whether or not a binding agreement had been created, and pending a determination of that issue, the purchaser took the step of registering a caveat in respect of its claim of a right to purchase the subject lands under the disputed agreement. Without this caveat, there would be no practical impediment to the vendor selling the lands to a third party, thereby possibly rendering the purchaser's right to purchase the lands effectively moot. Yet there is no consideration by the Court as to the competing interests of the parties in this case as would normally be undertaken in an assessment of the balance of convenience portion of the tri-partite test. While the vendor's interest in the non-disclosure covenant is maintained, the purchaser's claim to protecting its claim to a right to purchase the lands is not expressly protected. One might have expected a preservation of the status quo ante by granting an in personam injunction preventing the vendor from selling or encumbering the lands until the issue of the existence or lack of a binding agreement could be determined.

\section{ENERFLEX SYSTEMS LTD. V. LYNN ${ }^{311}$ \\ 1. BACKGROUND}

This decision of the Alberta Court of Appeal confirms the theory emanating from a long line of previous judicial decisions that injunctions against former employees are difficult to obtain as the courts are generally unwilling to prevent, or even interfere, with the employee's ability to subsequently earn a livelihood. In this regard, note that the first part of the tripartite test is varied from requiring the applicant to show a "serious issue" to requiring the applicant to show a "strong prima facie case."

\section{FACTS}

Enerflex Systems Lid. (Encrflex) sought to enjoin a former employee, an accountant, from joining a competitor, allegedly in breach of a non-competition agreement. 


\section{DECISION}

The Court applied a form of the tri-partite test; however, on the first part of the test, the Court noted that the lower court had applied the "strong prima facie case" standard, rather than the more typical, and less stringent, "serious issue" standard. The Court of Appeal agreed that the higher standard is appropriate when the injunction would prevent a former employee from carning a livelihood, which was the case here, and found that Enerflex had failed to demonstrate a strong prima facie case. In particular, the Court noted that Enerflex was not privy to the non-competition agreement; rather, it had acquired the assets of a business that employed the employee from another entity. As such, the employer had not made any agreement directly with the employee itself. The Court held that common law principles operate to restrict the assignment of non-competition agreements with employees.

As to irreparable harm, the lower court determined that Enerflex's claim of irreparable harm was speculation and opinion and, in any event, that any harm that could be proven could be compensated by damages.

The balance of convenience pitted Enerflex's unproven claim that the employee had disclosed, and likely would continue to disclose, confidential information against the ramifications to the employee's career if the injunction was granted. The lower court had determined that the balance clearly favoured the employee's career over the yet unproved allegations that the employee had or was improperly using any confidential information.

The Court found that the chambers judge had made no error of law in applying the "strong prima facie case" test, and that her assessment of all of the facts before her was reasonable. Accordingly, it dismissed Enerflex's appeal.

\section{COMMENTARY}

Again, the standard is very high to qualify for an injunction to prevent a former employee from taking employment at a competitor. It would seem that, at a minimum, the employer must have strong evidence that its former employee does in fact possess information that is confidential and sensitive to the employer and that the employee is using that information to solicit the employer's customers. Moreover, an employer should not expect to be able to rely on a confidentiality agreement that it inherits as part of an asset purchase transaction.

\section{MEDICAL LABORATORY CONSULTANTS INC. V. CALGARY HEALTH REGION 272}

\section{BACKGROUND}

This is an interesting case that centres primarily on the balance of convenience and the public interest rather than on the standard analysis of serious issuc/strong prima facie case and irreparable harm. It is also a useful example of the different standards that apply to mandatory injunctions as compared to prohibitive injunctions. 


\section{FACTS}

The plaintiff sought a mandatory injunction (i.e., one requiring a positive act rather than one prohibiting an act), namely that the Calgary Health Region (CHR) continue to make payments to it in respect of medical and pathology services. The claim was founded on an alleged contract and on the statutory obligation of the Government of Alberta to pay for health care services and the delegation of that authority to CHR.

\section{DECISION}

The Court held that where a mandatory injunction is sought, it is appropriate to use the "strong prima facie case" standard in the first part of the tri-partite test. It found that the lower court erred in its assessment of the contractual claim. The lower court had found that it was not clear whether a contract between the parties in fact existed, but then proceeded on the assumption that there was a contract and held that there was a strong prima facie case that the assumed contract had been breached. The Court held that it is antithetical to doubt whether a contract exists and then find that there is a strong prima facie case that the contract was breached. However, the Court found that the lower court did not err in finding that the plaintiff had a strong prima facie case on the statutory claims.

The Court gave little consideration to the issue of irreparable harm. The Court may have inferred, but did not expressly state, that the termination of payments to the plaintiff would have resulted in the cessation of the plaintiff's entire business operation. If that was the case, other cases have held that the same or similar circumstances amount to irreparable harm.

The Court's decision in this case turned primarily on the balance of convenience. The Court noted that the respondents would suffer "obvious harm"273 (from which the inference drawn above is taken). However, the Court also gave weight to the public interest, saying that "[i]t is not reasonable in these times to dismantle an entity providing health services that are crucial and in great demand before the courts have had an opportunity to review the legislation." 274

\section{COMMENTARY}

This case provides a useful example of the higher standard that applies to mandatory injunction applications. The case is also interesting in its consideration of the balance of convenience, which incorporates not only the balance between the parties, but also - quite appropriately and consistently with prior cases - the public interest. 


\section{E. ANDERSON V. TRANSGAS LTD. ${ }^{275}$}

\section{BACKGROUND}

This decision represents another interesting conclusion along "public interest" lines in an injunction application.

\section{FACTS}

The applicants were a group of landowners who had sued Transgas Ltd. (Transgas), a subsidiary of the provincial Crown corporation SaskEnergy that is responsible for the transportation of natural gas throughout Saskatchewan, for damages resulting from decreased well water qualities, decreased water levels, and resulting diminishment in property values. They also sought an injunction to prevent Transgas from operating ground water works until the trial of the damages question, and also an order suspending the licence granted to them by the Saskatchewan Watershed Authority (SWA). SWA had granted a licence to Transgas to use water from the aquifer in question for the purpose of constructing a gas storage facility.

\section{DECISION}

On the test of whether there was a serious issue to be tried, the chambers judge rejected the plaintiffs' claim to compel the Minister to order an environmental impact study, holding that conducting such a study was wholly within the discretion of the Minister. However, the chambers judge accepted that the plaintiffs had raised a serious issue as to whether they had a claim in nuisance and negligence.

With respect to irreparable harm, the chambers judge found that all of the claims of the plaintiffs were compensable in damages and, therefore, it was not possible to establish irreparable harm.

Last, on the issue of where the balance of convenience lay, the chambers judge noted that having operational storage facilities is critical to proper functioning of the natural gas industry and its ability to deliver natural gas without interruption. Accordingly, the balance of convenience favoured refusing the injunction.

\section{COMMENTARY}

At first blush, it is difficult to understand how diminished water quality and access would not be more important than natural gas storage facilities or how they could be compensated by money damages (and thus not be irreparable harm). However, it must be remembered that the plaintiffs were seeking compensation for the diminishment of their property values as the result of the diminished water access and quality. The chambers judge noted that this was not a question of people going thirsty because it was incumbent on Transgas to ensure an alternative adequate supply of water and "to do so even if it is unclear that Transgas' 
operation caused the problem with a well." ${ }^{276}$ Claims of this nature are clearly compensable in money damages.

Transgas also had two strong defences to the injunction application. First, it was a Crown corporation engaged in a type of public work, namely the creation of gas storage facilities for the betterment of the province as a whole. Second, it possessed a licence to use the water and had not offended the licence. In another case cited by the plaintiffs, Canada (Nasional Capital Commission) v. Pugliese, ${ }^{277}$ a similar claim in similar circumstances was maintained successfully, but in that case the National Capital Commission had taken more water from the aquifer than its licence permitted.

\section{SPLIT TITLE}

\section{A. Xerex Exploration LtD. V. PETRO-CANADA ${ }^{278}$ \\ 1. BACKGROUND}

This decision deals with the issue of what duties, if any, are owed by the holder of the rights to a shallow formation to the holder of the rights to a deeper formation.

\section{FACTS}

Xerex Exploration Ltd. (Xerex) held an Alberta Crown petroleum and natural gas licence for all zones below the Bluesky-Bullhead (the Deep Rights) in certain lands, including one particular section (Section One). The Deep Rights were due to expire on 3 December 1996. Petro-Canada held the petroleum and natural gas rights in all zones to the base of the Bluesky-Bullhead (the Shallow Rights) in certain lands, including Section One. On 7 November 1996, Petro-Canada applied to the AEUB to drill a well (the 1-1 Well) in Section One to the base of the Rock Creek Zone (which is found below the Bluesky-Bullhead formation). The AEUB corrected Petro-Canada's application and issued a licence to PetroCanada allowing it to drill the $1-1$ Well provided that the well was not to be drilled "more than 15 metres below the base of Bluesky-Bullhead."279

Petro-Canada proceeded to drill the 1-1 Well. As target depth approached it began taking samples at $1 \mathrm{~m}$ intervals and continued to do so for several metres into the Deep Rights. The well site geologist examined the drill cutting samples from the Deep Rights and reported to head oflice in Calgary on the morning of 20 November that those samples had oil shows.

Ibid. at para. 44.

[1979] 2 S.C.R. 104.

23, 2005 ABCA 224, 367 A.R. 201 [Xerex].

2:4 This over-hole allowance of $15 \mathrm{~m}$ is set out in the AEUB's Directive 56 in order to accommodate logging tools and casing so that a zone is able to be explored to its fullest extent. In addition. the drilling licence stipulated that Petro-Canada was to take drill cutting samples at $5 \mathrm{~m}$ intervals from $30 \mathrm{~m}$ above the Bluesky-Bullhead to total depth, which, properly interpreted, means to the bottom of the shallow rights, not to the bottom of the over-holc allowanct. 
Petro-Canada stopped drilling, had an internal meeting, and decided to have one of its landmen contact Xerex's President by telephone to see if Petro-Canada could acquire the Deep Rights. A conversation took place, but the evidence as to what occurred during it differed. Petro-Canada's landman testified that Xerex agreed during the telephone call to a sale of the licence, subject to a 3 percent gross overriding royalty. Xerex's President testified that he did not agree to anything during the telephone call, but that he did agree to sell the Deep Rights for a 3 percent gross overriding royalty a couple of days later when he received a written offer from Petro-Canada. Also, during the telephone conversation the two men discussed the fact that Petro-Canada was in the process of drilling the Shallow Rights. Xerex's President testified that he specifically inquired as to whether Petro-Canada had drilled into the Deep Rights and was told that it had not. Petro-Canada's landman testified that he did not recall being asked that particular question, but acknowledged that he did not volunteer during the call the fact that Petro-Canada had already drilled into the Deep Rights and that it had taken a number of samples.

Either way, after the completion of the telephone call Petro-Canada continued drilling the 1-1 Well and drilled an additional $7 \mathrm{~m}$ into the Deep Rights and took further samples, again without disclosing anything to Xerex. Four days after it signed the sale agreement respecting the Deep Rights with Xerex, Petro-Canada applied to convert its newly-acquired Deep Rights licence to a lease, due to the discovery of evaluated petroleum or natural gas sufficient to meet regulatory requirements. The lease was issued and Petro-Canada put the $1-1$ Well on production from the Deep Rights.

Petro-Canada later sold the lands, including the Deep Rights and the 1-1 Well, to Progress Energy Ltd. (Progress), without any reservation of the 3 percent gross overriding royalty to Xerex. Progress developed the lands and created more value. Neither Petro-Canada nor Progress ever paid any royalties to Xerex. Then, at an Alberta Landman's Association Prospect Exchange, Xerex's President picked up a package of brochures at Progress's booth. He noticed and "was astonished to discover that Progress was producing oil, quite profitably," ${ }^{2 k 0}$ from the $1-1$ Well over which it held the 3 percent gross overriding royalty.

\section{DECISION}

The trial decision in this case has been ably discussed in an earlier version of this article. ${ }^{281}$ In that decision, LoVecchio J. essentially found that there had been a misrepresentation by Petro-Canada to Xerex through its silence and incomplete disclosure, and awarded $\$ 8,133,000$ in damages to Xerex. Petro-Canada appealed that decision and Xerex cross-appealed on the quantum of damages.

In its decision, the Court of Appeal went further in its analysis of the issue of misrepresentation, finding that there had in fact been an actual misrepresentation by false statement during the initial telephone conversation. It went on to discuss that, in order to be actionable, the misrepresentation must be material and must be relied upon by the receiving 
party to induce it to enter into the contract. The Court of Appeal had no difficulty concluding, as had the trial judge, that if the true state of Petro-Canada's drilling activity had been disclosed to Xerex it would not have entered into the gross overriding royalty agreement. It also believed the evidence of Xerex's President concerning the telephone conversation in question, i.e., that he had directly asked Petro-Canada if it had drilled into the Deep Rights, and that the direct response to his question was "no." As a result, it found that the materiality and reliance requirements had been met.

The Court of Appeal accepted that two parties dealing at arm's length have no general duty to disclose facts to one another. However, citing a number of authorities it held that if disclosure is made, it must be accurate and complete. Thus, when Petro-Canada raised the subject of drilling and failed to disclose the full extent of Petro-Canada's drilling activity (i.e., the further $7 \mathrm{~m}$ ), it amounted to a falsehood either because it was a half-truth when said in the first place or because it became untrue before the agreement was made.

Although the trial judge had not ruled on the issue of fiduciary duty given his finding that an actionable misrepresentation had occurred, the Court of Appeal went on to conclude that a fiduciary duty arose when Petro-Canada drilled and tested the $15 \mathrm{~m}$ over-hole allowance. The Court held that Petro-Canada was required to tell Xerex that it had already entered the Deep Rights during their negotiations. Then, if Petro-Canada had been asked whether anything had been observed or discovered as a result of such entry, it was obliged to disclose that information.

The Court found that this duty arose out of the particular facts and circumstances, rather than out of the obligation to act in good faith. It adopted the position of a fiduciary in the sense described by La Forest J. in Hodgkinson v. Simms. ${ }^{282}$

As I noted in Lac Minerals, however, the three-step analysis proposed by Wilson J. encounters difficulties in identifying relationships described by a slightly different use of the term "fiduciary", viz., situations in which fiduciary obligations, though not innate to a given relationship, arise as a matter of fact out of the specific circumstances of that particular relationship.... In these cases, the question to ask is whether, given all the surrounding circumstances, one party could reasonably have expected that the other party would act in the former's best interest with respect to the subject matter at issue. Discretion, influence, vulnerability and trust were mentioned as non-exhaustive examples of evidential factors to be considered in making this determination. ${ }^{283}$

The particular circumstance in this case was that Xerex had the exclusive right to explore and exploit the Deep Rights. Petro-Canada only had the exclusive right under its lease to explore and exploit the Shallow Rights, and the drilling licence did not expand these rights. The drilling licence permitted Petro-Canada to drill the $15 \mathrm{~m}$ over-hole allowance but it did not give Petro-Canada a licence to acquire information from the allowance. The Court held that, by deliberately taking samples from the Deep Rights and analyzing them (which neither its ownership of the Shallow Rights nor its drilling licence permilted it to do), Petro-Canada 
gained information and put Xerex in an "extremely vulnerable position." ${ }^{8-4}$ As a result, by depriving Xerex of the benefit of that information and using it in connection with its negotiations with Xerex, Petro-Canada breached a fiduciary duty it owed to Xerex.

The Court of Appeal concluded its analysis by finding that the lower court had not erred in its calculation of damages.

\section{COMMENTARY}

False representation - whether through express statement, half-truth, or deliberate failure to subsequently correct a statement originally thought to be true - has been part of the law for centuries. If a particular question is asked by a party, and answered falsely by the party to whom the question is posed, and if the false answer leads the inquiring party to make a contract that it would not have made if it had known the correct information, then the inquiring party will be entitled to rescission or damages.

However, what is noteworthy here is the Court's extension of fiduciary duties to PetroCanada. Specifically, the Court said that "the duty imposed on Petro-Canada in this case, when it went to negotiate the purchase and sale of the Deep Rights, was to disclose that it had drilled into them, and to answer any question Xerex might have had about what might have been seen or discovered." ${ }^{2 * s}$ The duty thus described by the Court goes beyond an obligation simply to answer questions truthfully or completely if raised - it suggests a positive obligation to disclose, unsolicited, the fact of drilling and then answer whatever questions arise.

It seems clear that the Court was sending a strong message to discourage any thoughts or practice in the industry of embarking on information-gathering exercises outside of the terms of licences and legal boundaries. The justification offered for such an extension is obvious; however, while the desire to impose a duty is understandable in these circumstances, a number of troubling questions remain, some of which the Court itself noted and stated that it preferred to leave to another occasion.

First, the Court left unanswered the question of whether a duty to disclose would arise if Petro-Canada determined from its review of the samples taken from the Deep Rights that there was nothing noteworthy about them. The troubling part of this question is that observation is often in the eye of the beholder. Suppose Petro-Canada had seen nothing in the Deep Rights, but nevertheless felt compelled by a fiduciary obligation to report Xerex as the holder of those rights. Petro-Canada would have then made a statement to Xerex along the lines of: "We inform you that we have drilled into the Deep Rights and have taken samples and see nothing particularly useful there." That statement would not, if wrong but believed to be true when made, be a falsehood. Nevertheless, if incorrect, that statement would undoubtedly prompt action (or more likely inaction) on the part of Xerex, in which case the licence would have been lost through expiry. Morcover, if negligently made, the statement could be actionable. In other words, the duty as imposed by the Court may force a trespasser to be the guarantor of its opinion that there is "nothing particularly useful." 
Worse still, suppose that the samples contained oil shows but, from the economic perspective of Petro-Canada, they were not significant enough to warrant production. However, what is not economic to Petro-Canada may be economic to a different producer. Would the obligation imposed by the Court here have required Petro-Canada to inquire further into Xerex's economic circumstances, or alternatively to have divulged to Xerex what PetroCanada considers "economic"? None of the possible answers to any of these queries is comforting.

Second, the Court posed, but left unanswered, what would happen if Petro-Canada had not concluded an agreement with Xerex, but simply waited for the licence to expire and then attempted to secure a new licence for the Deep Rights directly from the Crown. ${ }^{286} \mathrm{By}$ characterizing the duty as fiduciary, this question becomes somewhat rhetorical and there is little doubt as to the answer. Throughout the common law world, a fiduciary has a duty not to take advantage of knowledge obtained because of a fiduciary relationship but, unlike the greater part of the common law world, in Canada fiduciary duties extend well beyond a prohibition against using confidential information to include a positive duty to inform the party to whom the duty is owed.

Finally, if the party that obtains such information intends to do nothing, does that party have a positive duty to disclose? The quandary that results here is very similar to the first unanswered question above. If you do something, you must do it properly. If you do nothing, you risk breaching a fiduciary duty. This Catch- 22 may ultimately create as many questions for industry as this decision puts to rest. However, whether those questions actually arise in the future is speculation at this point, and in Xerer the Court obviously had to address, in a clear and meaningful way, the very real and serious issues before it.

\section{CONFLICTS OF INTEREST}

\section{A. 3464920 CANADA INC. V.STROTHER ${ }^{287}$}

\section{BACKGROUND}

Since the decision of the Supreme Court of Canada in R. v. Neil, ${ }^{288}$ law firms and their clients have had a heightened level of concern about the circumstances in which a firm can act against a former client or for a new client. Usually, this question turns on whether the firm is in possession of confidential information that could potentially harm the other client.

This important decision of the British Columbia Court of Appeal provides an interesting counterpoint to the confidentiality issue and turns instead on a solicitor's continuing duties of loyalty to the former client, even after termination of the retainer.

Petro-Canada may have opted not to proceed down this path because, in Alberta, the Deep Rights would have been put up for public tender through a Crown land sale and there would have been no guarantec that Petro-Canada would have been the suecessful bidder. Moreover, even if the lands had been retumed to and re-iendered by the Crow'n and Petro-Canada had been the successful bidder. Xerex would have leamed of this fact given the public nature of Crown land sales and its suspicions would undoubtedly have been raised at that point. 


\section{FACTS}

The plaintiff, formerly known as Monarch Entertainment Corp. (Monarch), sued its former solicitor, Mr. Strother (Strother) for breaching fiduciary duties and his duty of loyalty. Strother and his firm held an exclusive retainer agreement to advise Monarch in relation to certain tax-exempt investment vehicles. After those incentives were eliminated, Strother advised Monarch that it could not continue such investments profitably, resulting in Monarch winding up its related business and terminating its exclusive retainer agreement with the solicitor's firm.

Some time thereafter, Monarch's chief operating officer, Mr. Darc (Darc), resigned. Darc then approached Strother with a plan for circumventing the new tax rules to continue profitable investments in the same sector in which Monarch had been investing. Without disclosing the new information to his client, Strother successfully obtained an advance tax ruling. With the tax ruling in hand, he then resigned from his law firm and joined Darc's new company, earning millions of dollars. Monarch was not informed of the application or the resulting tax ruling.

Monarch later learned of the defendants' actions and brought a claim against Strother and Darc seeking an accounting of profits and various heads of equitable relief. Monarch never re-entered the field even with the knowledge of the favourable tax ruling.

\section{DECISION}

The trial judge dismissed the claims against both Strother and Darc. On appeal, the British Columbia Court of Appeal allowed the appeal against Strother but dismissed the appeal against Darc.

The Court of Appeal found that Strother had breached his duty of loyalty and that he was in a position of conflict in two senses: a conflict of duty between two clients and a conflict of interest between himself and his original client. The Court found that these duties continued notwithstanding that the initial retainer between Strother and Monarch had been terminated. The Court similarly rejected the argument that had the solicitor advised Monarch of the possible plan for circumventing the new tax rules, he would have breached his duty to his new client, Darc, by disclosing information confidential to that relationship. The Court stated:

If it was confidential information of Mr. Dare's, I agree that Mr. Strother could not disclose it to Monarch. But having undertaken to work towards a tax ruling that would contradict the continuing advice he had given and was continuing to give Monarch - either by his silence or by telling its principals there was "nothing to be done" - Mr. Strother had placed himself in a position of conflict of duty and of interest.... In this case, Mr. Strother should have told Mr. Dare that he "could not aceept this business". His failure to do so meant that he could not be candid with his existing client. Monarch. regarding a subject on which he had given clear and unequivocal advice. He would have to "hold back" on what he would normally advise Monarch, in order to protect the confidentiality of his other client, Mr. Dare (and the Sentinel Hill companies.) Once he had accepted Mr. Darc's retainer (and become entitled to a share of profits) he then was required in my view to cease acting for both clients and as thave already said, to alert Monarch to the possibility that his previous advice was incorrect. Although it is not necessary to decide the point for the purposes of this appeal, I would also suggest that he was precluded from going into business with Mr. Darc, even if he had first lef his law 
practice - that, to quote the well-known words of Lord Chancellor in Keech v. Sandford.... he was the "only person of all mankind" who could not take up the opportunity - at least without the fully informed consent of Monarch. ${ }^{2 \times 9}$

The Court also rejected Strother's argument that he was not under a duty to advise Monarch by reason that the advance ruling was a long shot: "The fact that the 'long stot' became less of a long shot only gradually does not in my opinion provide a defence or diminish his duty."290 The Court further found that as soon as Strother entered into an agreement with Darc, he was in a position of personal conflict as it was in his personal interest to ensure that Monarch remained ignorant of what he knew, i.e., that a favourable tax ruling was a possibility. It did not matter to the finding of fiduciary duty breach that Strother be found to have acted in bad faith or fraudulently: "The breach of duty alone is sufficient to entitle the beneficiary to a remedy." ${ }^{291}$ Nevertheless, the Court found that Strother had taken pains to ensure that no one at his old firm let slip the fact that the firm was acting for Darc's company in connection with the advance tax ruling.

In response to the trial judge's finding that solicitors must be free to act for clients who are competitors, the Court stated:

Not only were Monarch and Sentinel Hill "commercial competitors"; Monarch was relying for advice from a lawyer who was entilled to 50 per cent of the profits and equily shares of Sentinel Hill. Unbeknownst to Monarch, Mr. Strother himself was "the competition". He had both a direct personal interest, and an indirect professional interest, in seeing that Monarch remained in the dark and that Sentincl Hill was first to market with the new structure. Even assuming the confidentiality of the "new idea", this was a breach of the duty of loyally he and his firm owed Monarch. To paraphrase the elements of that duty as described in Neil, his duty to avoid conllicting interests, his duty of commitment to the client's cause, and his duty of enndour with the elient on matters relevant to the retainer were all compromised. The "bright line" was crossed. ${ }^{292}$

The Court also disagreed with the trial judge's decision that Monarch suffered no damages by reason that it failed to re-enter the market once it learned of the favourable tax ruling, i.e., that there must be a necessity for a causal connection in damages to recover from a fiduciary. In response, the Court stated:

But the necessity for a causal connection does not mean that before the beneficiary of a fiduciary duty may recover, he or she must prove that "but for" the breach, he or she would have taken up the opportunity in question and would have made the profits in question - elfectively, to prove a loss. The traditional, and supposedly "inflexible", rulc of Equity is that "the court ... is not entitled ... to receive evidence, or suggestion, or argument as to whether the principal did or did not suffer any injury in lact by reason of the dealing of the agent; for the safery of mankind requires that no agent shall be able to put his principal to the danger of such an inquiry as that." 293 
A beneficiary of a fiduciary duty is thus entitled to choose between damages or an accounting. Although the accounting remedy is used to redress and deter fiduciary wrongdoing, particularly in secret profit cases, the Court of Appeal did find that there are some limits to the accounting remedy, noting the decision of La Forest $\mathrm{J}$. in Hodgkinson: $:^{294}$

In Canada, the Supreme Court has not had a case of this kind; but in recent years it has moved away from an approach that regards the available remedies and applicable principles as either strictly equitable or strictly common law. It has said, for example, that a "court exercising equitable jurisdiction is tot precluded from considering the principles of remoleness, causation and intervening act where necessary to reach a just and fair result." ${ }^{2 y s}$

The Court also noted with approval the case of Waman Imernational Lid. v. Dwyer, 396 a decision of the High Court of Australia, where the Court cited several examples where it may not be just to order a full accounting of profits. The Court of Appeal stated:

\footnotetext{
As has been seen. the general approach taken by the High Courl in Wormon International is consistent with the Supreme Court ol" Canada's endorsement of "flexibility" and "common sense" in recent decisions involving equitable remedies. The question then is the extent of the accounting or disgorgement approprialc in Mr. Strother's case, given on the one hand the "underlying prophylactic purpose of fiduciary liability"... and on the other hand, the principle that the fiduciary's liability should not go beyond what he or she gained in consequence of the breach of duly. ${ }^{297}$
}

The Court then concluded that Strother must be required to account for and disgorge to Monarch all benefits, profits, interests, and advantages he received or would be entitled to receive, directly or indirectly from or through any of Darc's companies, notwithstanding the argument that much of the success of the business was a result of a third party's contribution of expertise and a later merger with Alliance Atlantis. In addition, the Court ordered all of the defendants that are owned or controlled by the solicitor to cooperate lully in the accounting and declared, because of Strother's ease of access to offshore corporations and accounts, that Strother and all other entities owned or controlled by him are "constructive trustees in favour of Monarch in respect of the profits, interests and benefits referred to above."298

\section{COMMLNTARY}

This case provides a clear example of the continuing duties owed by solicitors to their clients, even former clients. One subtext of the judgment could be characterized as a duty to correct prior information. In this regard, reference is made to Xerex ${ }^{299}$ (discussed above in Part XVII), in which a duty to correct a prior statement resulted in the imposition of a fiduciary duty. By contrast, in this case it was the existence of the fiduciary duty itself that required the correction to the previous advice given by the lawyer.

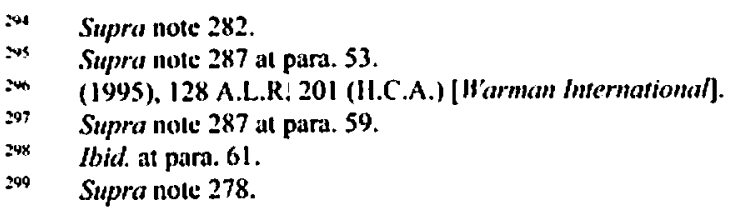

